Pamiętnik Literacki 2016, 3, s. 33-91
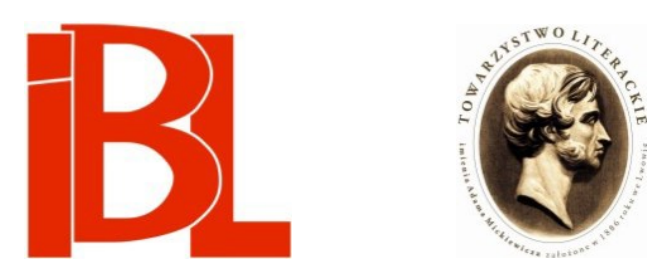

Jerzego Ficowskiego oferta piosenkowa $(\mathrm{z}$ dziejów kultury popularnej w PRL)

\author{
Jerzy Kandziora
}




\title{
JERZEGO FICOWSKIEGO OFERTA PIOSENKOWA (Z DZIEJÓW KULTURY POPULARNEJ W PRL)*
}

\begin{abstract}
Poeta-tekściarz
Wśród pozostawionych przez Jerzego Ficowskiego prac pisarskich - obok wybitnych dokonań w dziedzinie twórczości oryginalnej: tomów poezji, zbioru opowiadań fantastycznych Czekanie na sen psa, gawęd starowarszawskich, baśni cygańskich dla dzieci, obok obszernego dorobku przekładowego, a także wybitnych zasług cyganologa: odkrywcy Papuszy, autora książki Cyganie na polskich drogach, która znalazła się $\mathrm{w}$ wielu domach inteligenckich, poszerzając wrażliwość społeczną na kulturowe odmienności, obok wreszcie edycji dzieł Brunona Schulza i szkiców biograficznych o nim, książki o Witoldzie Wojtkiewiczu - istnieje również domena aktywności artystycznej mniej znana, która jednak w pewnym sensie umożliwiła Ficowskiemu realizację wymienionych tu dzieł. Domeną tą było pisanie tekstów piosenek dla czołowych wykonawców polskiej estrady.

Początki twórczości piosenkowej poety sięgają współpracy z Państwowym Zespołem Pieśni i Tańca „Mazowsze”, trwającej od wczesnych lat pięćdziesiątych XX wieku ${ }^{1}$. Ficowski był przez jakiś okres kierownikiem literackim „Mazowsza”. W roku 1957 odbył z tym zespołem podróż artystyczną do Londynu ${ }^{2}$. Później oddawał się tej twórczości z jeszcze większą intensywnością. W latach sześćdziesiątych owocem zadzierzgniętej przez niego krótko po wojnie przyjaźni z Cyganami będą teksty pisane dla artystów z kręgu romskiego: Randii (Bronisławy Korsun), Michaja Burano (Wasyla Mihaja), Sylwestra Masia Kwieka. Ten ostatni, młody Cygan z Otwocka, był przez Ficowskiego wspierany w poczatkach swej kariery (m.in. próbne nagrania w radiu, wizyty u kompozytorów, „ustawienie” repertuaru, występ w Opolu, nagranie płyty), a później ich przyjaźń trwała przez wiele lat ${ }^{3}$. Dom wiejski
\end{abstract}

* Artykuł powstał w ramach projektu badawczego finansowanego ze środków Narodowego Centrum Nauki przyznanych na podstawie decyzji nr DEC-2011/03/B/HS2/04352.

1 W zespole rękopisów J. Ficowskiego w Gabinecie Rękopisów Biblioteki Uniwersytetu Warszawskiego natrafiłem na roboczy list-notatkę założyciela „Mazowsza” T. Sy g i e ty ń s k i e go (1896-1955) do J. Ficowskiego, datowany na 9 VII 1952 (obecnie w zbiorach Bibl. Narodowej w Warszawie; dalej do tego archiwum odsyłam skrótem BN).

2 J. Fi c ow ski, Po osiemnastu latach. „Orzeł Biały” (Londyn) 1957, nr 9, z 2 III.

3 Zob. listy M. Kwiek a do J. Ficowskiego $\mathrm{z}$ lat 1963-1989 (BN). 
Ficowskiego w Gąsiorowie nieopodal Zarąb Kościelnych, zwany cyganówką, był miejscem spotkań poety i jego bliskich $z$ artystami cygańskimi, przyjeżdżającymi tam wraz $z$ rodzinami ${ }^{4}$.

W latach sześćdziesiątych i siedemdziesiątych piosenki Ficowskiego śpiewali także m.in.: Anna German (będąca również kompozytorką muzyki do wielu jego piosenek), Sława Przybylska, Stenia Kozłowska, Maryla Rodowicz, Zdzisława Sośnicka, Irena Santor, Halina Kunicka, Regina Pisarek, Alicja Majewska, Aneta Łastik, Jerzy Połomski, Andrzej Zaucha, Mieczysław Wojnicki, Jarema Stępowski, Jerzy Michotek. Największym przebojem stały się, oczywiście, Jada wozy kolorowe z 1970 roku (muz. S. Rembowski) w wykonaniu Rodowicz. Ale ponadto popularne były takie piosenki Ficowskiego, jak - z okresu współpracy z „Mazowszem” - Polonez warszawski (muz. T. Sygietyński) i Furman (muz. ludowa, wyk. S. Jopek ${ }^{5}$ ) oraz Woziwoda (muz. M. Sart, wyk. J. Michotek), Jak zostanę wielka pania (muz. E. Dębicki, wyk. Randia), Szlifierz warszawski (muz. S. Rembowski, wyk. J. Stępowski), Wiatr mieszka w dzikich topolach (muz. M. Sewen, wyk. A. German), Taka prawda nieprawdziwa (muz. M. Sart, wyk. A. German), To chyba maj (muz. i wyk. A. German) ${ }^{6}$.

Z estradą wiązała Ficowskiego m.in. bliska znajomość z Jerzym Grygolunasem, współtwórcą Festiwalu Piosenki Polskiej w Opolu. W jego monografii tego festiwalu poeta widoczny jest na zdjęciu w składzie jury drugiej edycji tej imprezy (1964 rok) ${ }^{7}$. Własne piosenki Ficowskiego nagradzane były na festiwalu opolskim (w 1963 roku wyróżniono Balladę cygańska, muz. M. Święcicki, wyk. M. Burano) i na Międzynarodowym Festiwalu Piosenki w Sopocie: w 1961 (II nagroda za Woziwodę, muz. M. Sart, wyk. J. Połomski) i 1970 roku (III nagroda i nagroda specjalna za Jada wozy kolorowe, nagrody I i II wówczas nie przyznano) ${ }^{8}$. W roku 1971 Ficowski mówił o około 30 napisanych do tej pory piosenkach ${ }^{9}$. Twórczość tę musiał później dość intensywnie kontynuować, skoro ostatecznie liczba jego tekstów piosenkowych przekracza $z$ pewnością znacznie liczbę 200.

W autokomentarzach wyrażających stosunek do własnej działalności piosenkowej Ficowski wskazuje, iż, po pierwsze, podstawowy dla tej aktywności był mo tyw zarobkowy - zdobywanie środków finansowych, które pozwalały realizować inne, poważniejsze plany. Sfera piosenki i sfera ambitnej twórczości były pod względem wysokości honorariów zupełnie niewspółmierne: „pracowałem kilka lat nad książką, za którą otrzymałem honorarium o ileż mniejsze od tantiem za same

4 Cyganówkę i jej gości wspominały podczas spotkań ze mną zarówno Krystyna Ficowska, starsza córka Wandy i Jerzego Ficowskich (rozmowa z 22 VI 2010), jak i druga żona poety, Elżbieta Ficowska (rozmowa z 14 I 2011).

$5 \quad$ Ojciec wokalistki jazzowej Anny Marii Jopek.

6 R. W ol ań s k i, Pop, rock, folk. Leksykon polskiej muzyki rozrywkowej. T. 1: A-M. Warszawa 2003, s. v. Ficowski Jerzy.

7 J. Grygoluna s, Festiwale opolskie. Warszawa 1971, s. 236.

8 Zob. Wolańs ki, op. cit., t. 3: Dyskografia, aneksy, s. 406-407.

9 Światy kolorowe. Z J. Ficowskim rozmawia K. N a st ulanka (1971). W zb.: Wcielenia Jerzego Ficowskiego według recenzji, szkiców i rozmów z lat 1956-2007. Wybór, oprac., wstęp P. S o m m e r. Sejny 2010, s. 575. Nie jest dla mnie jasne, czy poeta wspominając o 30 piosenkach miał na myśli tylko te teksty piosenkowe, które zaistniały na estradzie, czy też wszystkie, jakie napisał. 
Wozy kolorowe. Zająłem się piosenką, chcąc stworzyć sobie warunki do pisania nieopłacalnych rzeczy" ${ }^{10}$. Po drugie, silnie podkreślany jest przez Ficowskiego fakt, że układanie piosenek jest dla niego po prostu c zas em różnym (w domyśle - pośledniejszym) od tego, który służy właściwej twórczości:

Nie widzę żadnego związku między moją liryką a tekstem piosenkowym. Żądają innego warsztatu, sterowania wyobraźnią, inny mają adres. Nie potrafię równocześnie być i poetą, i „tekściarzem”, i prozaikiem $^{11}$.

A w rozmowie przeprowadzonej przez Wojciecha Wiśniewskiego określa Ficowski pisanie piosenek jako „artystyczne "usługi dla ludności"” 12 .

Te dwa motywy jeszcze silniej, jakby wyostrzone i sprowadzone do czysto już życiowych realiów, pojawiają się we wspomnieniach. W wywiadzie dla radiowej Dwójki z 2003 roku Ficowski opowiada, jak to jego córeczka, reagując na obawy mamy (,przymało pieniędzy jest i nie wiadomo, co zrobimy”), rzekła: „Jak to co? Pójdziemy do ZAiKS-u”. Wypłacający od czasu do czasu tantiemy za piosenki ZAiKS jawił się jej jako „sezam, w którym wszystko się znajdzie, czego się pragnie” ${ }^{13}$. Krystyna Ficowska zapamiętała twórczość piosenkową ojca jako stale obecną na forum rodzinnym, począwszy od jej lat dziecinnych ${ }^{14}$.

W relacji Elżbiety Ficowskiej ta twórczość była czymś w rodzaju domowej produkcji na ciężkie czasy, w której i ona uczestniczyła (była autorką ponad 50 piosenek) ${ }^{15}$. Wspomina zamówienia kierowane ze strony wojska ${ }^{16}$, a także podkreśla, że napisanie przeboju w latach sześćdziesiątych i siedemdziesiątych radykalnie rozwiazywało wszelkie problemy finansowe:

Jak się udało trafić w taki przebój, to ten przebój był nieprawdopodobnie popularny i dawał wielkie pieniądze, i nie miał konkurencji przez jakiś czas. Słyszałeś to wszędzie, na wszystkich stacjach radiowych i telewizyjnych. A w przypadku Wozów kolorowych to było jeszcze przecież we wszystkich demoludach bardzo popularne ${ }^{17}$.

Piszę dla moich bliskich dalekich. Z J. Ficowskim rozmawia W. W i śn n e w s ki (1983). W zb.: jw., s. 597.

11 Poetyckie strony świata. Z J. Ficowskim rozmawia M. Sprusiński (1971). W zb.: jw., s. 583.

12 Piszę dla moich bliskich dalekich, s. 597.

13 Jerzy Ficowski - refleksje i wspomnienia. Cz. 3: Jerzy Ficowski opowiada o poszukiwaniach sposobu na życie $w$ polskiej rzeczywistości lat 50. Nagranie dla Programu 2 Polskiego Radia, sporządzone przez B. Przą d kę, pochodzi z 2003 roku. Znajduje się na stronie: http://www.polskieradio.pl/8/755/Artykul/364583,Jerzy-Ficowski-\%E2\%80\%93-refleksje-i-wspomnienia (data dostępu: 19 VI 2016).

14 Rozmowa z K. Ficowska, z 22 VI 2010.

15 Zob. Z. Adrjański, Kalejdoskop estradowy. Leksykon polskiej rozrywki 1944-1989. Artyści, twórcy, osobistości. Warszawa 2002, s. v. Ficowska Elżbieta. Ficowska pisała swoje piosenki, ale także uprawiała twórczość dla dzieci, pod pseudonimem nazwiskowym Elżbieta Bussold.

E. F i c ow s k a przywołuje tu postać J. Laua, literata, kierownika Wydziału Repertuarowego Domu Wojska Polskiego, który zamawiał piosenki u kolegów pisarzy: „Przychodził i mówił: „Koledzy, może macie jakieś teksty“. Oni płacili za nie. Piosenka mogła nigdy więcej nie ujrzeć światła dziennego, mogła nie mieć muzyki, ale składałeś tekst i oni wypłacali pieniądze" (rozmowa z E. Ficowską, z 14 I 2011).

Ibidem. 
W innym miejscu dodaje, że z tantiem za Jada wozy kolorowe dokończyli z mężem budowę domu letniskowego i żyli bardzo dobrze przez długi czas ${ }^{18}$.

Także drugi wątek wyznań Ficowskiego: całkowita rozłączność tych sfer pisarskich, jakimi była piosenka $z$ jednej strony, a wysiłek twórczy podczas pisania książek czy poezji - z drugiej, znajduje wyraziste potwierdzenie we wspomnieniu dotyczącym lat pięćdziesiątych. Powiada Ficowski o pisaniu tekstów do piosenek:

zupełnie [mnie] nie cieszyło, bo wytrącało moje pióro z rytmu tak strasznie, że ja później przez dwa lata nie byłem $\mathrm{w}$ stanie zrobić niczego innego, zanim to ze mnie nie spłynęło, tak jak nikotyna $z$ byłego palacza $^{19}$.

I relacja jego żony dotycząca czasów późniejszych:

on zawsze mówił [...], że jak on te piosenki pisze, to jest taki czas skażony, taki czas, kiedy on nie może robić niczego innego. I na przykład, jeżeli pisze książkę, to musi zrobić przerwę, odłożyć książkę, wziąć całkiem inne pióro, i tym innym piórem przez jakiś czas pisać piosenki. Potem - powiedział - musi to odłożyć, przewietrzyć siebie i pokój, złapać równowagę. I dopiero wraca do swojego pisania ${ }^{20}$.

Podkreśla się tu dwie okoliczności: po pierwsze, piosenki są źródłem zarobku, po drugie, pisanie piosenek to inny czas, moment zmiany pióra. Interesująca jest komplementarność obu aspektów. Mamy do czynienia z intencjonalną s e p a r a c ja twórczości piosenkowej, jako skażonej, wymagającej zmiany pióra (co nawet przypomina nieco kategorię cygańskiego „skalania”), od twórczości zasadniczej, a po wtóre, $\mathrm{z}$ silnym podkreślaniem sł u ż e b n e g o, usytuowanego głównie w wymiarze materialnym, w wymiarze profanum, znaczenia twórczości piosenkowej w życiu poety. I dopiero na trzecim miejscu mowa (zarówno w autokomentarzach Ficowskiego, jak i w relacji jego drugiej żony) o tym, że nie umiał pisać słabych tekstów, bo był po prostu przede wszystkim poetą. Można, oczywiście, powiedzieć, iż tak wyglądała realność, ale jednocześnie trzeba zauważyć, że układa się to w pewna narrację, w której ramach egalitaryzm, wpisany w rolę autora tekstów piosenek, zostaje wyraźnie oddzielony od elitaryzmu, cechującego rolę poety i badacza kultur.

\section{Charakterystyka zbioru, czyli żywioł piosenkowy}

Podjęta na potrzeby tego artykułu rejestracja tekstów piosenkowych Ficowskiego w formie kartoteki doprowadziła do sporządzenia zapisów 198 tytułów utworów oraz skopiowania tych tekstów do celów badawczych ${ }^{21}$. Kwerendę wykonałem w dwóch zasobach: w Gabinecie Rękopisów Biblioteki Uniwersytetu Warszawskie-

Ibidem.

Jerzy Ficowski - refleksje i wspomnienia.

Rozmowa z E. Ficowską, z 14 I 2011.

Dla porównania, M. Siedlecka, autorka obronionej w Warszawie w 2010 roku w Instytucie Badań Literackich PAN rozprawy doktorskiej Poetyka tekstów polskiej piosenki popularnej lat 60-tych i 70-tych XX wieku (promotor prof. dr hab. M. Głowińs ki. Mpis w Bibl. IBL PAN. Warszawa, sygn. Masz 6186) uwzględniła, jak podaje, 106 piosenek Ficowskiego, udostępnionych jej w ZAiKS-ie (ibidem, s. 162, przypis 301). W orbicie tej pracy znalazło się ogółem 367 piosenek J. Kondratowicza, K. Dzikowskiego, Ficowskiego i S. Grochowiaka (ibidem, s. 157). 
go $^{22}$ oraz w archiwum Stowarzyszenia Autorów ZAiKS w Warszawie. W pierwszym $\mathrm{z}$ tych zbiorów zarejestrowałem 140 tekstów, w drugim 146, jednakże wiele $\mathrm{z}$ nich wystapiło w obu zbiorach, tak że w rezultacie końcowa liczba odnalezionych tekstów piosenek jest mniejsza niż suma obu zbiorów. Piosenek napisał Ficowski na pewno więcej, tyle że nie znajdują się one ani w ZAiKS-ie, ani w BUW-ie. Świadczą o tym spoczywające w BUW-ie cząstkowe wykazy tytułów piosenek, na których figurują utwory niedostępne w obu zbiorach. Kilkanaście dalszych, nie występujących gdzie indziej tytułów znajduje się w internetowym Katalogu Polskich Płyt Gramofonowych $^{23}$. A nadto był Ficowski, jak już wspomniałem, autorem produkcji w poetyce socrealistycznej czy na zamówienie wojska (relacja E. Ficowskiej), których już jednak nie poszukiwałem ${ }^{24}$.

Przy okazji niejako, mając dostęp do archiwum ZAiKS-u i natrafiając w zasobach BUW-u także na pewną liczbę piosenek autorstwa Elżbiety Ficowskiej (podpisującej, jak wspomniałem, swoje utwory nazwiskiem Bussold) - postanowiłem zewidencjonować również jej teksty. Początkowo nie podejrzewałem jednak, że dla refleksji nad piosenkami Ficowskiego będzie to miało jakieś znaczenie, i widziałem te dwa zbiory piosenek - Ficowskiego i jego żony - jako całkowicie rozłączne. Zarejestrowałem i sporządziłem kopie w sumie 42 piosenek Bussold, znajdujących się w obu zasobach. Ponadto na wspomnianych już wykazach cząstkowych, przechowywanych w BUW-ie, pojawiło się 12 dalszych tytułów piosenek przypisanych Bussold, $\mathrm{z}$ których połowa jednak, jak się przekonałem, była dostępna w formie tekstów sygnowanych nazwiskiem Ficowskiego!

Chciałbym zatrzymać się przez jakiś czas przy tych doświadczeniach $z$ identyfikacja piosenek, sporządzaniem ich kartoteki, ponieważ coś, co początkowo wydawało mi się czynnością zupełnie rutynowa, doprowadziło do zaskakujących obserwacji, rzucających światło na „życie” piosenki, problem jej powstawania, autorstwo, transformację tekstu - zwłaszcza w kontekście poezji Ficowskiego. Nie sposób zrozumieć w pełni jego twórczości piosenkowej, a chyba też gatunku piosenki estradowej w ogólności, jeśli się owych spraw nie poruszy, zanim podejmie się interpretację konkretnych tekstów. Powiem od razu, że bardzo wiele zawdzięczam w tej części rozważań rozmowie $z$ Elżbietą Ficowską, która - gdy ją pytałem o autorstwo niektórych piosenek - była w prawdziwym kłopocie, ale jednocześnie impas w tej sprawie uświadamiał mi, im dłużej trwało nasze spotkanie, że nie da się tak po prostu zamknąć kanonu tekstów Jerzego Ficowskiego i Elżbiety Bussold jako dwóch rozłącznych zbiorów. I że w związku $z$ tą niemożnością rodzi się realny problem badawczy, stanowiący ważny przyczynek do wiedzy o piosenkach.

Nie zamierzając $\mathrm{w}$ jakimkolwiek stopniu umniejszać dorobku piosenkowego

Artykuł ten powstawał w okresie, gdy archiwum Ficowskiego znajdowało się w Gabinecie Rękopisów Biblioteki Uniwersytetu Warszawskiego, stąd w tekście głównym, opisując przebieg kwerendy, lokalizuję je - BUW. W przypisach zaś do przywołanych rękopisów używam w formie skrótu już lokalizacji dzisiejszej: BN.

23 Katalog Polskich Płyt Gramofonowych można znaleźć na stronie: www.kppg.waw.pl (data dostępu: 19 VI 2016).

24 Kilka edycji piosenek Ficowskiego w poetyce socrealistycznej znajduje się w zbiorach Bibl. Narodowej. Są to m.in. teksty do muzyki T. Syg i e tyń s ki e go (Spótdzielcze przyśpiewki. Warszawa 1953) czy K. S e r o ckiego (Piosenka szofera. Warszawa 1954). 
Ficowskiego, który był twórca zdecydowanej większości zachowanych tekstów, trzeba powiedzieć, iż istnieje pewien, liczacy kilkanaście pozycji, katalog piosenek Ficowskiego i Bussold, w których sprawa autorstwa ulega wyraźnej k o m plikac j i, z a t a r c i u. Równocześnie może on być dla nas atrakcyjnym badawczo terenem wyodrębnienia pewnych interesujących właściwości samego tekstu piosenkowego, a zarazem sposobu jego powstawania i cyrkulacji. Właściwości, które ukazują różnicę między piosenką a tekstem poetyckim, twórczością piosenkową a twórczością wysokoartystyczna, wreszcie między samym obiegiem a dojrzewaniem tekstu piosenkowego i poezji. Przy czym będę tu mówił przede wszystkim o piosenkach (Ficowskiego i Bussold), bo odmienność statusu oraz sposobu krystalizacji utworu poetyckiego, którymi rządzą - odpowiednio - pryncypia oryginalności i definitywności, będzie na owym tle tekstów piosenkowych oczywista.

Podstawowym moim doświadczeniem jako rejestratora piosenek Ficowskiego, doświadczeniem swoistej redundancji, stało się odkrycie, że ten sam, pojedynczy tekst piosenkowy może mieć różne oznaczenia autorstwa (Ficowski i Bussold) oraz że może występować pod kilkoma tytułami. Pierwszą i najgłębiej osadzoną w tekście (choć nie twierdzę, iż najczęstszą) przyczyną przemiennego określenia autorstwa piosenki wydaje się dwuosobowa praca nad tekstem. Przykładowo: utwór Stara cerkiew. Ma on dwa warianty - pierwszy, dwuzwrotkowy, podpisany nazwiskiem Bussold (muz. M. Sewen) i spoczywający w archiwum ZAiKS-u, oraz drugi, w zbiorach BUW-u, sygnowany przez Ficowskiego, bez nazwiska kompozytora, stanowiący rozszerzona przez poetę wersję piosenki żony. Drugi tekst jest dłuższy o jedną zwrotkę. Ficowski, zachowując koloryt łemkowski i nastrojowość pierwszej wersji, w dodatkowo napisanej zwrotce wprowadza, jak się zdaje, motyw historyczny wygnania i zapomnienia, być może odnoszący się do tzw. akcji „Wisła”:

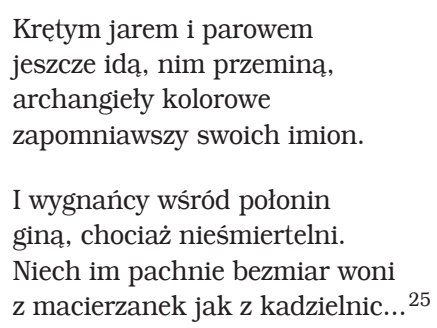

Innym przykładem kontynuacji czy rozwijania inicjujaccego pomysłu jednego $z$ autorów przez drugiego są dwie piosenki: Spotkanie z nikim i Przychodzi do mnie nikt. Pierwsza $z$ nich, napisana przez Bussold wraz z Krystyną Szajkowicz (żona Marka Sarta, która skomponowała muzykę), nosiła początkowo tytuł Nikt, na dwóch egzemplarzach maszynopisu w BUW-ie poprawiony ręką Ficowskiego na Spotkanie $z$ nikim. Na jednym $\mathrm{z}$ nich twórca zmienia także nazwisko Bussold na swoje. Jednakże w archiwum ZAiKS-u egzemplarz tej piosenki sygnowany jest nazwiskiem

25 Ten narzucajacy się w lekturze obu wersji obraz ewolucji piosenki potwierdziła w rozmowie ze mną E. Ficowska, opisując rolę męża w drugiej fazie powstawania tekstu. 
autorki $^{26}$. Piosenka Ficowskiego Przychodzi do mnie nikt jest wprawdzie utworem nowym, odmiennym tekstowo, ale niezwykle podobnym sytuacyjnie (motyw nocy, spotkania) i opartym na tym samym pomyśle - „nikt” jest personifikacją tęsknoty. Piosenka Przychodzi do mnie nikt (i jej wariant tytułowy Szafirowy nokturn) spoczywa w archiwum ZAiKS-u jako utwór Ficowskiego.

A wreszcie przykład ostatni owej płynności autorstwa - udokumentowany listem Ficowskiego fakt przerobienia przez niego piosenek Bussold Wesoły gil i Zapalny John „sprzed kilkunastu lat”, celem ponownego wprowadzenia ich w obieg estradowy. Nowe, rozszerzone teksty piosenek wysłane zostaja do kompozytora Lucjana Kaszyckiego wraz z listem wyjaśniającym charakter zmian i sprawę autorstwa:

Wesoły gil ma obecnie dodatkowe trzecie canto, które - jak sądzę - dobrze rozwija i zamyka całość. [...] Zapalny John uległ znaczniejszym zmianom. Tekst jest dłuższy, w co drugim czterowierszu znalazła się refrenowa przyśpiewka z powtórzeniem czwartej linijki. Całość jest mimo to bardziej zwarta tekstowo i konsekwentna poetycko, zawiera szereg nowych pomysłów opartych na tej samej naczelnej ,zapalnej" metaforze, tok balladki jest płynniejszy i z pewnością lepszy niż poprzednio. [...] Do autorstwa żony dopisałem moje współautorstwo (za jej zgodą i aprobata), ale - jako że rzecz pozostaje „w rodzinie” - nie jest konieczne „dorejestrowywanie” w Zaiksie mojego nazwiska, choć można je podawać przy ewent[ualnych] publikacjach i nowych wykonaniach ${ }^{27}$.

Jak widać z podanych przykładów, mamy w piosenkach do czynienia ze swoistym zniesieniem rygoru oryginalności autorstwa, rygoru tak typowego dla klasycznego wiersza, tzw. poezji oryginalnej. Także w relacjach rodziny Ficowskiego na temat pisania piosenek wyraźnie zaznacza się różnica w samej, by tak rzec, aurze twórczej, jaka towarzyszyła, $z$ jednej strony, pisaniu przez poetę tekstów piosenkowych, z drugiej zaś - wierszy. Ta pierwsza czynność dopuszczała osoby postronne, wykorzystywanie cudzych pomysłów, wspólne tworzenie albo też przejmowanie inicjatywy w momencie impasu. We wczesnym okresie obserwowała to córka poety:

Piosenki tośmy pisali [...] też trochę wspólnie, rodzinnie. [...] siadało się u niego [tj. Ficowskiego] w pokoju i tatuś coś na rybkę przynosił. Bo współpracował z Markiem Sartem przede wszystkim ${ }^{28}$.

W podobnym duchu wspomina tworzenie piosenek, zarówno swoich, jak i męża, jego żona:

Siadałam i pisałam dwie zwrotki, i gdzieś tam się zacięłam. Siedzę, myślę, przychodzi Jerzy i patrzy mi przez ramię, i mówi: wiesz co, a może tak, a może tak, mamy! Jest! ${ }^{29}$

I ta zasada dopuszczalnej współpracy podczas pisania piosenek działała, jak wspomina Ficowska, w obie strony. Natomiast zupełnie nie działała w przypadku poezji: „Gorzej było z wierszami. Wierszy nigdy nie pisaliśmy wspólnie”. Po czym odtwarza najwyższe rozdrażnienie poety, jeśli pierwsza lektura jego wiersza przez żonę wywoływała jakieś uwagi: „Wrrr, wściekł się, zabrał mi, trzasnął drzwiami, 
wszedł do pokoju, mniej więcej po dwóch godzinach, czasem trzech, wychodził, mówi: "A teraz?" "30

Innym powodem zniesienia w przypadku piosenek owego rygoru oryginalności autorstwa była zmiana nazwiska twórcy gotowej już piosenki motywowana względami oczekiwań rynku i szansą spełnienia się w realizacji estradowej. Gotowy tekst piosenki stanowił bowiem swego rodzaju towar, który (jeśli nie powstał do istniejącej już muzyki) należało - jak opowiada Elżbieta Ficowska uplasować, znajdując dla niego kompozytora i wykonawcę. Tę rolę swoistego akwizytora brała na siebie żona poety ${ }^{31}$. Pozyskanie kompozytora i wykonawcy było procesem często niełatwym, a byt piosenki kończył się niekiedy na samym tekście lub tekście $z$ muzyką, dla którego nie udało się znaleźć wykonawcy (nieraz zwyczajnie $z$ powodu braku sił i czasu) ${ }^{32}$.

Tak więc - obok realnego współtworzenia niektórych piosenek - to właśnie zwiększenie szansy piosenki na przebicie się i znalezienie dla niej kompozytora i wykonawcy było kolejną przyczyną, dla jakiej szereg tekstów sygnowanych w maszynopisach przez Bussold i figurujących w dostępnym w BUW-ie wykazie jej utworów wychodziło w świat pod nazwiskiem Ficowskiego. Jego żona przyznaje:

Zależało nam, żeby piosenka poszła. No, powiedzmy, ja napisałam piosenkę, ale wiadomo było, że jeżeli to będzie piosenka Jerzego Ficowskiego, to ona ma większe szanse [...]. Więc to był też argument, żeby czasem zmieniać autorstwo ${ }^{33}$.

Wskażmy kilka utworów na tej zasadzie zmieniających autora. Sa to zapewne te teksty, które w wersjach „domowych”, tych przechowywanych w BUW-ie, mają jeszcze sygnaturę Bussold, natomiast w archiwum ZAiKS-u, gdzie piosenki rejestrowało się z nazwiskiem kompozytora, a więc już „uplasowane”, przynajmniej jeśli chodzi o muzykę (sprawa wykonawcy na tym etapie nie zawsze była oczywista), znajdowały się jako utwory Ficowskiego. Taką właśnie zmianę autorstwa z Bussold na Ficowskiego skonstatowałem w przypadku następujących piosenek: Bez ciebie tak mi dobrze (muz. S. Rembowski), Daj mi tęczę na niedzielę (muz. A. German), Diabet-stróż (muz. T. Woźniak), Jesień sny ma zielone (muz. S. Rembowski; utwór ten w wersji sygnowanej przez Bussold zawiera nazwisko kompozytora R. Czubatego; maszynopis piosenki w BUW-ie opatrzony jest poprawkami Ficowskiego, prawdopodobnie dostosowujacymi ją do nowej melodii), Stary Nango (muz. L. Kaszycki), Zajaczek z lusterka (muz. E. Sojka; autorstwo Bussold potwierdza tu figurowanie tekstu w wykazie jej piosenek) ${ }^{34}$. Zapewne nie jest to pełna lista piosenek, które „zmieniły” autora z owych najzupełniej pragmatycznych powodów. ka do J. Ficowskiego (z 21 III $1970\langle$ Rzeszów〉. BN) z trasy koncertowej, w którym autor wspomina o menadżerskim pomyśle żony poety: „Jestem bardzo ciekaw, jak układają się Biecie sprawy stworzenia zespołu”, po czym informuje, że nie udało mu się na razie znaleźć cygańskich muzyków do tego zespołu.

Trudne były np. początki przeboju Jadą wozy kolorowe, od którego powstania nawiązała się współpraca Ficowskich z kompozytorem S. Rembowskim (rozmowa z E. Ficowską, z 14 I 2011).

Ibidem.

Na marginesie odnotujmy, że opisanego przeze mnie procederu podmiany autora nie była świado- 
Śledząc fenomen tej piosenkowej swobody (z punktu widzenia poezji wysokiej) w traktowaniu autorstwa tekstu, jego atrybucji, który nadaje piosence odrębny rys, jako gatunkowi popularnemu, dotykamy także, oczywiście, tematu samej techniki pisania piosenek. Jej opanowanie pozwoliło Bussold tworzyć piosenki na tyle dobre, iż mogły uchodzić za piosenki jej męża ${ }^{35}$. W sam gatunek piosenki wpisana jest tak duża doza schematu i konwencji, iż przy znajomości tej techniki, przy talencie Bussold i podobieństwie wrażliwości obojga autorów możliwe było pod piórem żony Ficowskiego powstawanie piosenek, które przyjmowano bez żadnych wątpliwości jako utwory jego samego ${ }^{36}$.

Ostatnią wreszcie piosenkową osobliwością, o której chcę wspomnieć, związana ze specyficznym obiegiem piosenki jako gatunku popularnego, osobliwościa, która ujawniła się w trakcie rejestracji tekstów Ficowskiego i Bussold, okazała się zmienność podstawowego elementu identyfikującego piosenkę, jaki stanowi ty t u 1 u tw or u. Taka wielowariantowość tytułów w wypadku tekstów poezji wysokoartystycznej jest zjawiskiem wyjątkowym, zdarza się bodaj tylko w utworach poezji anonimowej i ulotnej, rządzącej się pod niejednym względem podobnymi do piosenki regułami obiegu. Rejestrując i czytając teksty piosenkowe, przekonałem się, że trafiają się takie, w których pod różnymi tytułami kryje się ta sama treść. Przeprowadzenie drugiej alfabetyzacji - według incipitów (stosowanej w dokumentalistyce właśnie przy rejestracji utworów anonimowych i ulotnych) - pozwoliło wykryć szereg tekstów, które występowały pod dwoma, a nawet trzema tytułami. W rezultacie, w sporządzonym przeze mnie podstawowym wykazie piosenek Ficowskiego, obejmującym 198 pozycji, znajduje się 28 odsyłaczy do piosenek funkcjonujących pod dwoma i więcej tytułami.

Powody zmiany tytułu już ukończonego tekstu mogły być wielorakie. W przypadku piosenki Ficowskiego pierwotnie zatytułowanej Rzeka, i pod tym tytułem opublikowanej w prasie codziennej ${ }^{37}$, w egzemplarzu złożonym w ZAiKS-ie (muz. A. Zaucha) widnieje odręczna poprawka zmieniająca tytuł na Naga rzeka. Zapewne zadecydowały tu względy wykonawcze (utwór pod tym tytułem prezentował zespół Dżamble), chęć podkreślenia w ten sposób tzw. szlagwortu. Przyczyną zmiany tytułu moga być także daleko idące zmiany wprowadzone do piosenki (wariantowy tekst bywał rejestrowany w ZAiKS-ie jako dwa utwory, np. Nie tak łatwo i Kto mi zabroni (muz. R. Żyliński〉). Elżbieta Ficowska opisuje również sytuację, gdy zgłoszony już do ZAiKS-u tekst wraz z muzyką nie znajduje wykonawcy i nie przynosi tantiem. Zdarzało się wtedy, że pojawiał się wykonawca zainteresowany taką wa-

ma Siedlecka (op. cit.), traktując w swym opracowaniu kilka piosenek Bussold jako teksty Ficowskiego.

O samym zajęciu się pisaniem piosenek powiada E. Fic ow sk a (rozmowa, z 14 I 2011): „Ja się tego nauczyłam. Bo to jest rzemiosło. Po prostu trzeba wiedzieć, jak to się robi. Oczywiście, jest jeszcze kwestia jakiejś wyobraźni poetyckiej, bardziej lub mniej, tematu, tego, o czym się pisze. [...] Ale poza tym, jeżeli masz tzw. szlagwort albo "rybkę", dostajesz od kompozytora, no i musisz do tej "rybki» dostosować tekst [...], to jest trochę taka robota, jak rozwiązywanie krzyżówki”.

36 Było to zresztą źródłem satysfakcji autorki, która powiedziała mi w rozmowie (z 2 III 2011) odnośnie do piosenek: „To, że Jerzy podpisywał czasem swoim nazwiskiem coś, co ja napisałam, to dla mnie było wielką nobilitacją. Ja się cieszyłam. To znaczy, że bez wstydu mógł to podpisać sam”. 
kującą piosenką, ale chciał mieć do niej inną muzykę. Należało wówczas uzyskać na to zgodę autora pierwotnej muzyki. Otrzymawszy tę zgodę, tekst piosenki z nową muzyką rejestrowało się raz jeszcze jako nowy, odrębny utwór, oczywiście pod innym tytułem. Zmianę tytułu, która wynikała ze zmiany autora muzyki, obserwujemy m.in. w takich tekstach Ficowskiego, jak Trzy pierścienie = Jestem wiatru narzeczona, Obcy = Jesteś mi obcy, Ballada o niebie i ziemi = Otwarta droga, Przychodzi do mnie nikt = Szafirowy nokturn.

Podsumowujacc te refleksje dotyczace powstawania oraz obiegu piosenek Ficowskiego i Bussold, można powiedzieć, że tekst piosenkowy był w pewnym sensie tworem przejściowym, nieporównanie silniej niż tekst poetycki reagującym na naciski okoliczności zewnętrznych, rynkowych, dostosowującym się do nich w różny sposób i z różnym skutkiem. I temu podporządkowane były zabiegi wokół tekstu. Cel finalny stanowiło wykonanie estradowe, nagranie na płycie, choć, jak już wspomniałem, powołując się na relację Elżbiety Ficowskiej, wiele piosenek zatrzymywało się w stadium samego tekstu, dla którego nie udało się pozyskać autora muzyki. Dla innych odnajdywało się kompozytora, ale też nie wszystkie $z$ tych piosenek trafiły następnie na estradę. Zdaniem Elżbiety Ficowskiej, ponad połowa $z$ tekstów spełniła się muzycznie i wykonawczo.

\section{W stronę popularności}

W dotychczasowych rozważaniach, posiłkujących się m.in. obszerną relacją Elżbiety Ficowskiej, zwróciłem uwage na pozaartystyczne, egzystencjalne, socjologiczne aspekty i motywy pisania utworów piosenkowych; na to, że pryncypium oryginalności, niepowtarzalności artystycznej, jednoosobowości autorstwa bywa w nich naruszane; że wreszcie nie wszystkie piosenki osiagają pełnię wykonawczą i niejako z założenia część z nich „odpada w przedbiegach”. A zatem dużą rolę w ich przetrwaniu i żywej cyrkulacji odgrywa swoista otwartość tekstu na oczekiwania zewnętrzne - kompozytora, wykonawcy, słuchaczy, inaczej niż w przypadku utworów poetyckich, trwających we własnej, wyjątkowej niepowtarzalności. Opisane reguły krystalizowania się piosenek Ficowskiego, reguły ich obiegu społecznego, wprowadzają nas już pośrednio w problematykę samych tekstów. Są one w podstawowym wymiarze ofertą dla odbiorcy masowego, a ich istotę stanowi operowanie powszechnie akceptowanymi i zrozumiałymi toposami. Najpierw więc chciałbym się zając swoista typologią owej oferty piosenkowej, kładąc nacisk na wszystko to, co jest w tych piosenkach odpowiedzią na zbiorowe tesknoty i emocje.

Już sam katalog tematów, motywów piosenek Ficowskiego stanowi jakby mapę masowej wyobraźni i oczekiwań. Mapę, na której swojskość, potrzeba zakorzenienia się współwystępują $z$ marzeniem o dalekich światach i egzotycznych krainach, wycofanie się $\mathrm{w}$ intymność, prywatność, spotyka się $\mathrm{z}$ równie niezbędną dozą wspólnotowej, zbiorowej identyfikacji (piosenkowa publicystyka), rozpoznawanie się w nurcie teraźniejszości, we współczesnych realiach, sąsiaduje z zakorzenieniem się w historii, wpisanym w wiele piosenek cofających się ku przeszłości, lokalność - partykularyzm podwórka, dzielnicy, miasta - odnajduje rewers w otwarciu się na przestrzeń kraju, ludzkości czy nawet Kosmosu, a wreszcie to, co w jed- 
nych piosenkach zaspokaja potrzebę konkretu obyczajowego, w innych przynosi baśniowość i fantastykę czy intensywność natury.

Ten szereg opozycji można by zapewne nieco wydłużyć, ale należy podkreślić rzecz najważniejsza, że, z jednej strony, każda piosenka Ficowskiego jest realizacja któregoś $z$ biegunów tych opozycji, a jej potencjalny odbiorca ma się bez reszty identyfikować ze światem danej piosenki, z drugiej zaś - cały ten zbiór piosenek „zagospodarowuje” wszystkie oczekiwania (m.in. przestrzeni zamkniętej i otwartej, czasu bliskiego oraz dalekiego, wspólnoty i samotności) swoich odbiorców i także w ten sposób dostarcza im tak pożądanego utwierdzenia się we własnej tożsamości, emocjach. Można tu mówić o kolejnych obszarach wrażliwości zbiorowej, które zaspokajają te utwory.

\section{Kobieta i mężczyzna, czyli wieczny temat miłości}

Najobszerniejszą część całej twórczości piosenkowej Ficowskiego stanowią piosenki miłos ne (zalotne, „flirtujące”), których jest około $60^{38}$. Stosując zasygnalizowane przed chwila - i chyba najbardziej swoiste dla refleksji nad piosenka - kryterium oferty emocjonalnej, można, jak sądzę, wyodrębnić kilka stylów (obrazów) miłości, z którymi odbiorca piosenek gotów jest się identyfikować. Chciałbym je nazwać stylami: miejsko-inteligenckim, naturalistycznym i kulturowym. Wydaje się, że każdy $z$ nich prezentuje inny typ ekspresji doświadczenia miłości, sytuuje miłość w innych kontekstach, a także innego rodzaju żywioł percepcyjny, odmienna wrażliwość znajduje się u jego źródeł.

Styl mi ejsko - in teligencki piosenkowego opowiadania o miłości - warto podkreślić ten historyczny aspekt - związany był z nową formułą relacji kobietamężczyzna, $z$ nowym wzorcem intymności, jaki narodził się w latach powojennych, a powrócił w Polsce po październiku 1956. Odrzucał on konwencje romantyczne, racjonalizował te relacje. Uosabiają go choćby powieści Stanisława Dygata Pożegnania (1948; zekranizowana przez W. Hasa w 1958 roku, z sekwencja piosenki Pamiętasz, byłajesień, w wykonaniu S. Przybylskiej ${ }^{39}$ ) i Leopolda Tyrmanda Siedem dalekich rejsów (1952-1957) czy popaździernikowa twórczość Kazimierza Brandysa (m.in. Listy do pani Z. Wspomnienia z teraźniejszości 〈1958〉). Linia intymności prowadzacca przez te i inne dzieła literatury polskiej, wzbogacana przez recepcję prądów zachodnich (egzystencjalizm), sytuowała miłość z dala od znanych dotąd konwencji - jako obszar azylu, rezerwat prywatności, awers historii i zniewalających doświadczeń zbiorowych.

W miejsko-inteligenckim wzorcu piosenkowej miłości, który można by nazwać też „nowoczesnym”, „kawiarnianym”, „konwersacyjnym”, niewątpliwie atrakcyjne były takie składniki, jak dojrzałość, sceptycyzm, zaprawiona niekiedy gorzką ironią dorosłość. Pewien wymóg realizmu psychologicznego, sytuacyjnego, zapis strategii zowanego w innym miejscu.

Słowa do tej piosenki napisali A. Czekalski i R. Pluciński, muzykę: L. Kaszycki. S. Przybylska użycza w filmie swego głosu zza kadru aktorce A. Łubieńskiej. 
uczuciowej towarzyszą tu silnemu żywiołowi kolokwialności. Jeśli wspomniałem przed chwilą o różnych rodzajach wrażliwości percepcyjnej, leżących u podstaw każdego $z$ trzech stylów miłości piosenkowej, to ten wzorzec najsilniej osadzony jest właśnie w języku, konwersacji, dialogu. Tzw. szlagwort, występujący w tytule, bywa tu często urywkiem z rozmowy (Jesteś mi obcy, Nie wiem, po co, Nic takiego, Nie tak łatwo, Kto mi zabroni, Tak jest lepiej, To się nie liczy) - i już ten fakt sygnalizuje ową nadwrażliwość językową.

Dwa są, jak mi się wydaje, obszary identyfikacji odbiorcy, dwie sfery atrakcyjności piosenek Ficowskiego opowiadających miłość w stylu miejsko-inteligenckim. Po pierwsze, częste operowanie paradoksem i odwracanie utartych schematów romansu czy flirtu. Można mówić o pewnego rodzaju powabie inteligenckiego esprit, dowcipu, występującym w tej grupie żartobliwych przeważnie piosenek, nie pozbawionych jednak drugiego dna, refleksji egzystencjalnej. Ich bohater jakby źle znosi wszelka przewidywalność. Jasne jest, że odejście od schematu - aby było piosenkowo „chwytliwe” - musi się dokonać z pewną ostentacją. Stąd w tych piosenkach koncept słowny, paradoks pojawia się już w tytule utworu.

Co najmniej cztery utwory dobrze ilustrują owo żartobliwe odwrócenie schematu romansowego. Piosenka Bez ciebie tak mi dobrze, wypełniona rekwizytami współczesnej miłości („Dziś beze mnie się szwendasz, / chociaż miałaś kalendarz: / w nim datę wpisałem ci w kółko!”), przewrotnie ukazuje sytuację szczęścia jeszcze większego niż miłość, gdy kolejne dziewczyny odchodzą lub nie przybywaja na spotkanie. W Feralnej dziewczynie „złe znaki” sygnalizowane przez bohaterkę stają się elementem flirtu. Bohater utworu Jak dobrze, że to nie raj „rozgrzesza” siebie i partnerkę $z$ biblijnego grzechu pierworodnego, by oddać się miłości prywatnej i zwyczajnej. W piosence Pokocham ciebie na złość natarczywy podrywacz („Co dzień twe listy i telefony, / [...] pleciesz słodkie androny") zostaje ukarany prawdziwa miłością („Ja ostrzegałam [...] / nie chciałeś słuchać, to masz!”).

Drugi obszar identyfikacji z bohaterem (częściej - bohaterka) otwierają piosenki w odmiennej, niekiedy gorzkiej tonacji, intensywniej angażujące się w psychologię relacji miłosnych. Sa to, by tak rzec, pi o s e n ki „k ry zy s o w e”, w których nie bezrefleksyjne, szczęśliwe kochanie, ale stany przed lub po kryzysie miłości, rozpadzie związku stają w centrum tekstu. Autor wewnętrzny piosenki jawi się tu jako ratownik złamanych serc albo przynajmniej doświadczony rezoner, sama zaś piosenka jest próbą dojrzałości, nie pozbawioną goryczy propozycją uporania się z bolesną pamięcią czy też $\mathrm{z}$ niepewnością i lękiem. W tym wariancie oferty emocjonalnej piosenki miejsko-inteligenckiej największą wartość dla współczesnego odbiorcy ma pozbawiony złudzeń obraz miłości nieszczęśliwej lub niespełnionej, która każdemu się może przydarzyć, a równocześnie propozycja pewnego życiowego heroizmu wpisana $\mathrm{w}$ te piosenki ${ }^{40}$. Tu też najczęściej pojawiają się sceneria

40 Warto dla porównania przywołać analizę - semantyczno-socjologiczną, a częściowo także w kategoriach psychiatrii klinicznej - wątków miłosnych amerykańskich piosenek bluesowych i popularnych, dokonaną na początku lat pięćdziesiątych przez przedstawiciela amerykańskiej Semantyki ogólnej S. I. Haya kaw ę (Popular Songs vs. the Facts of Life. W zb.: Mass Culture. The Popular Arts in America. Ed. B. Ros en berg, D. M. White. New York - London 1964. Przekład polski 
i rekwizyty miejsko-inteligenckiej miłości: kawiarnia, park, tłum uliczny, kartki z kalendarza, zegar z kukułka, pisanie listów, telefony, parasol, kwiaty.

Takie piosenki, jak Jesteś mi obcy, Kawiarenka na Piwnej, Nic takiego, Nie tak łatwo, To się nie liczy należą do portretów pamięci obolałej, spustoszonej odejściem ukochanego, zapisów autoperswazji bohaterki (bohatera), która na różne sposoby rozważa to, co się stało. W tekście Jesteś mi obcy czytamy, że może warto było się nie zakochiwać, by ocalić lekkość i czar kawiarnianych spotkań:

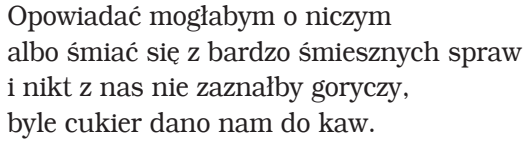

Może trzeba było zaprosić ukochanego, a potem „nie otworzyć drzwi”, by się przekonał, że „najsmutniej bywa, gdy / nic się nie ma, prócz tęsknoty” (Nic takiego). Może warto nie przechodzić zbyt szybko na „ty”, żeby nie wpadać w to „piekło” uczuć, kiedy niespodziewanie - jak w piosence Tak jest lepiej - ten zaimek będzie się szczególnie łatwo łączył ze słowem „odejdź”:

\footnotetext{
Wolę panu mówić: proszę pana -

w kawiarence $z$ lekka zadumana.

Bądźmy, proszę, troszkę oficjalni,

byłoby tych naszych spotkań nawet żal mi.
}

Te piosenki często są zawieszone między jakimś „niedokonanym” a tym, co się już chyba zdarzyło. Tak naprawdę nie wiemy czasem, czy to już mądrość „po szkodzie”, czy może jeszcze przed. Są więc takim naszeptywaniem uciekajacym od tonów dramatycznych. Otamowują ból rozstania, osadzając go w mądrościowych formułach jakichś przysłów, gier słownych, które maja jakby charakter zamawiania, zaklinania rzeczywistości i łagodzą rozpacz. Można to nazwać poetyką niedopowiedzeń, przemilczeń, eufemizmu. Kiedy bohaterka piosenki Nadzieja na dwoje nam wróży wyznaje: „Na wszelki wypadek już dzisiaj odchodzę, / [...] na wszelki wypadek - zapomnę", to porusza odbiorcę ta jej kruchość psychiczna, lęk związany $\mathrm{z}$ odrzuceniem, choć tytuł przywołuje $\mathrm{z}$ pozoru obiektywizująca kategorię losu („na dwoje babka wróżyła”). A w piosence Nasze słowa sa ze srebra rozpaczliwa nadzieja dziewczyny na usłyszenie upragnionego słowa $z$ ust ukochanego toczy cicha walkę ze zdroworozsądkową maksymą „słowo jest srebrem, a milczenie złotem”, która miała zapobiec w tym ich związku nadmiarowi słów:

\footnotetext{
Jakże dowiem się, że kochasz, gdy będziemy milczeć znów? Daj mi trochę, chociaż trochę srebrnych słów!
}

W. G órni cki i g o: Piosenka a życie. W zb.: Super-Ameryka. Szkice o kulturze i obyczajach. Wybór W. Górnicki, J. Kossak. T. 1. Warszawa 1970). Autor przypisał tekstom popularnych piosenek białej młodzieży amerykańskiej takie cechy, jak niedojrzałość, alienacja, self-pity, ucieczka w świat symboli i myślenia magicznego oraz przeciwstawił je życiowemu autentyzmowi i dojrzałości bluesowych tekstów miłosnych czarnej społeczności. 
Wszystkim tym szeptanym opowieściom z miłosnego szlaku, które tu nazwałem piosenkami w stylu miejsko-inteligenckim, towarzyszy, jak już podkreślałem, silny żywioł konwersacyjny, dialogowość, osadzenie w kolokwialności i grze słownej. Niespełnienie jest w dużej mierze tematem tych utworów, a obolała pamięć, pewnego rodzaju déjà vu: wspomnienie spotkania (Kawiarenka na Piwnej, Znajoma uliczka), echa niegdyś nuconej piosenki (Nie tak łatwo), miłosnej sprzeczki (To się nie liczy) buduja ich tkankę sentymentalną, wzruszeniową.

Na przeciwnym biegunie - biegunie miłości najczęściej spełnionej, na swój sposób archetypalnej - sytuuje się natomiast grupa piosenek natura lis ty c zny ch. Gdybym miał zdefiniować ich dominantę emocjonalną, to źródłem wiarygodności tych tekstów, powodem identyfikowania się $z$ nimi słuchaczy byłoby włączanie przez nie uczuć człowieka w prawa natury, pewien wykład logiki miłosnego spotkania, który przerasta pojedynczą wolę ludzką, poddaje ją rytmom natury, czyni cząstką krajobrazu i Kosmosu. Wpisuje w intensywny nurt przemian owej natury, jej odnowień i zmierzchów. Oczywiście, szkicuję to w dużym uproszczeniu, bo kontrapunkt natury w tych piosenkach przybiera rozmaite postacie, i to właśnie może być kryterium zróżnicowania piosenek miłosnych w obrębie stylu naturalistycznego.

Zapewne największą szansę identyfikacji stwarzają tu piosenki, w których owo zbliżenie kochanków do natury to jak gdyby nowa wersja sielanki, piosenki pasterskiej, pozbawiona, oczywiście, sztafażu rokokowego. Jest w nich jednak pierwiastek uwspółcześnionej arkadyjskiej utopii, na którą składa się pragnienie ucieczki od cywilizacji - głęboka wiara, że natura stanowi najwłaściwszą scenerię miłości - kreowanie przestrzeni zamkniętej, swoistego azylu, do jakiego nie maja przystępu złe siły tego świata. W omawianych piosenkach widzimy, z jednej strony, jakby roztapianie się człowieka kochającego (i kochanego) w pejzażu, uwalniające od lęków, od bolesnego wyodrębnienia, jak np. w piosence W leniwych trawach:

\footnotetext{
W leniwych trawach się zanurzmy

i chmur latawce wypuszczajmy

w ten wieczór od koniczyn duszny,

niezwykły taki, choć zwyczajny.
}

Zaciera się tu niekiedy granica między człowiekiem a natura, jak w utworze $\mathrm{Na}$ skrzydełkach brwi, opartym na powracajacym porównaniu brwi ukochanej do skrzydeł jaskółki:

\footnotetext{
Na skrzydełkach brwi od smutków odlecimy, jak późny ptak uciekałby od bliskiej zimy.
}

Dziewczyna na przemian uśmiecha się: „na skrzydełkach brwi lecisz gdzieś / do ciepłych krajów radości”, to znów smutnieje, a wtedy ukochany pyta: „Czemu wesołe skrzydełka brwi / stuliłaś bezradnie?” Arkadyjska słodycz tej scenki od początku do końca dyktowana jest przez ów animalizujący koncept. $Z$ drugiej zaś strony, zaznacza się tendencja do idyllicznego pomniejszania świata, budowania „niszy” miłosnej, dającej poczucie bezpieczeństwa i kameralne odosobnienie. Ta przestrzeń zamknięta miewa postać parasola, pod który dobrotliwy deszcz zagania 
ukochanych (Daj mi tęczę na niedzielę), poły płaszcza czy „dachu z gałęzi”, gdzie oboje się zmieszczą w chwili wiosennej ulewy (Poprośmy o deszcz), wreszcie „domku twoich dłoni”, dającego ochronę jakiemuś mitycznemu płomykowi miłości, palącemu się w wietrzną noc (Złoty płomyk).

Na drugim biegunie owej grupy piosenek o miłości bliskiej naturze odnajdujemy serię utworów nacechowanych swoistą wizyjnością. I zwłaszcza te teksty zaświadczają, że o ile w stylu miejsko-inteligenckiej miłości piosenkowej występował przede wszystkim żywioł mowy, o tyle w stylu naturalistycznym dominuje o b r az o w a n i e. Będzie to zatem seria piosenek, w których losy miłości, postać ukochanej wpisane zostaną w „mowę” pejzażu, jego skalę i rytm, w zmienność pór roku, trwanie natury i Kosmosu. Najważniejsze wydaje się tutaj uwznioślenie, przekroczenie codzienności, jakie dokonuje się poprzez ową konfrontację zwykłej, szarej, polskiej miłości czasów PRL-u z tętnem Ziemi i natury, to swoiste przeniesienie tej miłości w wymiar jak najdalszy od powszedniości dnia codziennego.

Piosenką takiego rodzaju jest np. wspomniana już wcześniej, spopularyzowana przez zespół Dżamble i Andrzeja Zauchę, Naga rzeka, w której o tytułowej rzece mówi się jak o kobiecie:

\author{
Byłaś naga. \\ A ubrałaś się w szum klonu. \\ Powłóczyście ci w tej sukni i zielono, \\ miękkim chłodem cię osłania od upału, \\ jej tkanina oszeptała ciebie cała.
}

I tak jak rzeka, dziewczyna, obiecując rozstanie, pozostaje zarazem „najwierniejsza i milcząca":

\author{
Jesteś tą, co pozostaje, choć ucieka. \\ Zostań taka, jaką byłaś: \\ naga rzeka.
}

Dość podobną metafore „rzeczną” przynosi piosenka Nas dwoje:

$$
\begin{aligned}
& \text { Jeszcze płyńmy objęci } \\
& \text { nurtem tej niepamięci, } \\
& \text { co przepływa jak rzeka. }
\end{aligned}
$$

W inny sposób los kochanków, koniunktury miłości wpisują się w poruszenia krajobrazu, obroty Ziemi w utworze Odejdziesz i tak, gdzie miłość jest zmienna jak pory roku, ekstatyczno-sezonowa, zamiera wraz z nastaniem jesieni:

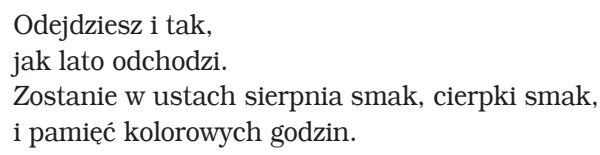

Także w piosence Najczerwieńszy kwiat miłość - pod postacią róży - więdnie pod koniec lata („i uwiędły płatki róży, / miła poszła gdzieś w świat...”), by powrócić za rok.

Jak wynika $z$ dotychczasowych interpretacji, przedstawieniami miłości w piosenkach Ficowskiego rządzi swego rodzaju dialektyka. Ukazywaniu miłości kame- 
ralnej - miłości jako azylu, ale też miłości swojskiej, z którą odbiorca mógł się bez trudu utożsamić, rozpoznać w niej siebie i w ten sposób jakby kompensować deficyt intymności, prywatności, jakiego doświadczał w aurze PRL-u - przeciwstawia się tendencja druga, $z$ kolei wynosząca miłość ponad szarość codziennego życia: ukazywanie miłości uniezwyklonej, uwznioślonej, dostrzeżenie jej w porządkach najbardziej fundamentalnych, w skalach makro, co pozwalało widzieć ja jako najważniejsze, pierwszoplanowe doznanie egzystencjalne, wpisane w porządek Kosmosu. Z jednej strony, nośnikiem miłości stają się w piosenkach język, dialog - wspólne dla wszystkich zakochanych doświadczenie konwersacji, $z$ drugiej zaś, na poły fantastyczne dzieła natury, krajobrazu, które tym pasjom udzielają swojego rytmu.

Obszarem dopełniajacym te dwa przedstawienia wydaje się trzeci styl piosenek o miłości, który nazwałem stylem k ult u r o wy m. Otwiera on piosenki na rozległa przestrzeń konwencji, tradycji, właśnie stylów ekspresji afektów miłosnych i posługuje się szeroko rozumianym „cy ta t e m” jako kanwą dla budowania piosenkowej dramaturgii. Jest on jakby zaproszeniem skierowanym do współczesnego słuchacza, aby poczuł się spokrewniony, bez względu na polityczne granice czy moment historyczny, z wielką, ogólnoludzką tradycją. Znów można tu mówić o nobilitacji miłości zwykłej, codziennej, o przedstawianiu jej jako pewnego kodu tradycji. I od razu trzeba powiedzieć, że stosunek piosenek do tej tradycji daleki jest od celebracji romantycznej, raczej sprowadzający na ziemię, czy może - sprowadzający do poziomu współczesnej wrażliwości dawne mity i motywy miłosne, także te literackie.

Ów klasyczny zabieg kultury masowej (by przykładowo wskazać przywołaną przez Umberta Eca twórczość George'a Gershwina ${ }^{41}$ ) pojawia się w najprostszej wersji w piosenkach Pod niebem Werony oraz Śladem Laury i Filona, gdzie wręcz powtarza się ten sam schemat - najpierw smutna konstatacja, że tamci kochankowie przeminęli (,,czuwają puste balkony”, „pozostał jawor po nich”), potem - przezwyciężenie smutku: teraz my spotkamy się, ,ja Julia i ty - Romeo [...] / pod niebem tym samym”,

\footnotetext{
Powędrujmy śladem Laury i Filona,

ucieknijmy $z$ miast zawistnych i nieufnych

i spotkajmy się w zielonych świata stronach -

pod jaworem, pod jaworem się umówmy!
}

Obok tych cytatów dosłownych z literatury, mamy też bardziej swobodne nawiązania do dawnych pieśni, ballad miłosnych, zwłaszcza sięganie do klasycznej topiki, rekwizytów, motywów romansowych, takich jak księżyc, gwiazdy, słowik, gitara, noc, spotkanie w nocy, które wprawdzie zawsze percypowane są w pierwotnym sentymentalnym odcieniu, jako znaki miłosnego afektu, ale przecież nie brzmią anachronicznie i nieatrakcyjnie, ponieważ Ficowski „angażuje” je w swoisty teatr piosenki, personifikuje, czyni np. ośrodkiem intrygi romansowej. Dzieje się tak choćby z księżycem pojawiającym się jako „ten trzeci”, złapany na miłosnej schadzce $\mathrm{z}$ ukochaną (Niewierna Marianna), to znów jako podglądający miłość zakochanych

41 U. E c o, Apokaliptycy idostosowani. Komunikacja masowa a teorie kultury masowej. Przeł. P. S a lw a. Warszawa 2010, s. 193-194. 
(Nie zawracaj nam głowy, księżycu). W piosence $O$ słowiku $w$ tonacji gwizd-dur w podobnej roli występuje słowik, którego drwiący gwizd przywraca humor nadąsanej ukochanej.

Zapewne ponownie pojawia się także w przywołanych utworach ów wzorzec gatunkowy sielanki wskazywany przeze mnie wcześniej w piosenkach o miłości „naturalistycznej”, jednakże tu dzieje się to już z wyraźną intencją cudzysłowową. Ficowski bowiem „obniża” klasyczne rejestry sielanki czy innych gatunków romansowych, kolokwializuje wypowiedzi, podmienia rekwizyty (,na grzebyku twym zabrzdąkam jak na lutni”, Serenada, serenada), a nade wszystko g r a konwencja. Element zabawowy, intertekstualny tych utworów znów stanowi jakby apel do inteligencji słuchaczy, odnajdujacych w piosenkach Ficowskiego poza obrazem miłości trudnej (styl miejsko-inteligencki), poza miłością jako archetypicznym zespoleniem $\mathrm{z}$ krajobrazem (styl naturalistyczny) również prawdę o umowności i ulotności spotkania miłosnego, jakie bywa zbiorem obietnic bez pokrycia, stanem rozbudzonej wyobraźni, grą miłosnym decorum.

Opowiada o tym piosenka Pod drewnianym kamieniem, w której dziewczyna ukrywa dla ukochanego „aksamitny nocy błam”, „do nieba bilet”, „nasze przytulone cienie”, „złoty sen”, na koniec zaś:

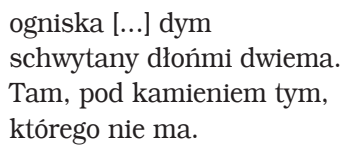

A także utwór To taka prawda nieprawdziwa, w którym kolejne zwrotki potęgują baśniowość przedstawionego świata („pojedźmy tam, za snu widnokragg, / na dno zwierciadła”, „zielone konie nas poniosą / nocą szeroką, „będziemy szli przez ptaków wrzawę / i gwiazd milczenie"), ale refren, a zarazem szlagwort, gasi tę rozgorączkowaną wyobraźnię, zawiera w sobie nutę dobrotliwej perswazji i jednocześnie wybaczającego przyzwolenia, że można jakby na miłość się umówić, i warto to zrobić:

To taka prawda nieprawdziwa, która się kłamstwem nie nazywa, stworzona przez nas.

Ta piosenka, ze swym dojrzałym zrozumieniem gry miłosnej, stoi naprzeciw „ciemnych” piosenek miłosnych, w których uczucie budzi lęk, rodzi odruch wycofania.

Cygańskość, czyli mit wędrówki i świata bez przymusu

Ficowski eksploatując topikę cygańską w swoich piosenkach ${ }^{42}$, jednocześnie świadom był, że tworzy w nich wersję cygaństwa dla gadziów, niewiele zgoła mająca wspólnego z realnym życiem tej grupy etnicznej w Polsce. Sam o tym zreszta wspo- 
minał, jak to relacjonuje Elżbieta Ficowska ${ }^{43}$. W tym nurcie piosenki estradowej ów stereotyp cygański był w pewnym sensie normą, choć, oczywiście, teksty Ficowskiego cechowały się nieprzeciętną inwencją artystyczną, wyraźnie odbiegająca od ówczesnych produkcji, których kontynuacją jest dzisiejsze - jak pisze Jacek Milewski - disco-romo, z owym nieśmiertelnym zaśpiewem „Ore, ore, szabadabada $a^{a m o r e "}{ }^{44}$. Ta właściwość piosenek „cygańskich”, jaka jest umowność rekwizytów i całkowita niechęć do wyjścia poza stereotypy cygańskiego życia i tradycyjne decorum, stanowi dla nas potwierdzenie, że utwory te jakoś szczególnie silnie osadzone są w oczekiwaniach odbiorczych, że w taki właśnie sposób najskuteczniej spełniaja owe oczekiwania ${ }^{45}$.

Punktem wyjścia refleksji na ten temat chcę uczynić szkic Stanisława Barańczaka, poświęcony topice wolności w polskiej piosence estradowej, w którym piosenkowy obraz Cygana i wspólnoty cygańskiej jawi się jako figuracja u c i e c z ki w w oln o s ć ${ }^{46}$. Barańczak wskazuje kilka motywów (nie tylko zresztą z piosenek Ficowskiego), które stanowią „persewerację wszystkich przestrzennych i czasowych symboli wolności", a następnie formułuje interesującą refleksję o równoczesnym, paradoksalnym statusie tej wolności w piosenkach „cygańskich” jako wartości „egzotycznej i w gruncie rzeczy niedostępnej”. Fakt, że personifikacją wolności nie jest tu „włóczęga, nomada, tramp” 47 , ale właśnie Cygan, postać należąca do obcego kręgu kulturowego, odrealnia niejako tę wolność i tym samym - sugeruje autor - zwalnia odbiorce piosenek od zaspokojenia owej tęsknoty za nią we własnym życiu.

W ujęciu Barańczaka piosenkowy Cygan to zatem tyleż nosiciel stereotypu wolnego życia, co rodzaj kamuflażu i kanalizowania rzeczywistych tęsknot wolnościowych, a więc w pewnym sensie postać pretekstowa. Takie czytanie toposu Cygana, w stylu „nic nie jest tak, jak się Państwu zdaje”, jest, oczywiście, możliwe, i bez watpienia Barańczak - jako badacz w owym czasie silnie inspirowany koncepcjami psychoanalizy społecznej (Erich Fromm i jego koncepcja „ucieczki od wolności”) - podpowiada tutaj kierunek interpretacji piosenek „cygańskich”. Poza motywami drogi, wędrówki, wiatru, „wiecznego święta” (w takich piosenkach, jak Jada wozy kolorowe czy Cygańska letnia noc), które stają się odczytywanym przez Barańczaka kodem wolności, równie - jak sądzę - sugestywne w aspekcie oddziaływania na odbiorcę sa powracające w piosenkach inne motywy: lasu, nocy, czerni i bieli (ciemności oraz jasności) czy końskiego galopu. I je także czytać można jako figury podświadomości, tym razem związanej ze sfera przede wszystkim e rosa,

Rozmowa z E. Ficowską, z 14 I 2011.

J. Milew s ki, Dym się rozwiewa. Poznań 2008, s. 32.

Dodajmy w tym miejscu niezbędną wzmiankę historyczną o tym, że „pieśni cygańskie” mają długą tradycję w muzyce poważnej. Jako swoisty gatunek stanowiły jedną $z$ konwencji romantycznych i pojawiały się zarówno w formie cykli Pieśni cygańskie, np. A. D v or ák a (op. 55, sł. A. H e y d u k) czy J. Brahms a (op. 103, sł. ludowe), jak i luźnych pieśni, np. ballada F. Lis z ta Trzej Cyganie (sł. N. Lenau).

46 S. B a ra ńczak, W kręgu estrady: piosenka i wolność. W: Czytelnik ubezwłasnowolniony. Perswazja $w$ masowej kulturze literackiej PRL. Paryż 1983 (podrozdz. Opozycje socjalne: od Cygana do rekruta).

Ibidem, s. 90. 
libido, „ciemnych” namiętności, transu, doznających wielokrotnego przeniesienia na te motywy obrazowe.

Pojawiają się one w wielu piosenkach jako mniej lub bardziej osadzone w ,akcji” piosenkowej, stanowiące zwykle główny element na poły baśniowej wizji czy fabuły:

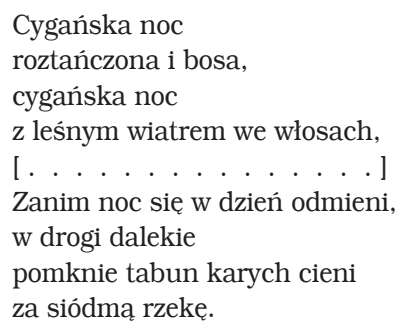

(Cygańska letnia noc)

Tymczasem chodź

i wsiądź na wóz!

Znajdę drogę do twych oczu,

znajdę drogę do twych ust.

Chodź! I w mroku

znajdę drogę do twych ust!

Chodź! Nie czekaj już!

Kali Mura, wsiądź na wóz!

(Kali Mura)

Kiedy porwę cię, dziewczyno, niech do lasu koń nas niesie, [.......... . ] ślub nam księżyc da pod jodła, by nas szczęście nie zawiodło nigdy.

(Kiedy porwę cię, dziewczyno)

Ucieknijmy w gęsty las,

nie odnajdzie, nie odnajdzie nikt już nas!

(Szarika-Marika)

Zarówno częstotliwość, jak i schematyzacja tego zestawu motywów są uderzające. Niekiedy - np. w piosence Czarna noc i biały koń - tworzą one nawet nie akcje, ale jakiś obrazowo-fabularny ideogram, którego podtekst miłosny zostaje znacznie głębiej ukryty, sugerowany kontrastem bieli (niewinności) i czerni (grzechu):

Boże, zgaś ten księżyc, zgaś,

bo mój koń ma śnieżną maść.

Spraw, by wielki księżyc znikł,

aby nas nie widział nikt!

[.......... ]

[ . . . . . . . . . ]

Czarna nocka, księżyc zgasł,

biały koniu, pędź przez las! 
W końcowej zwrotce pojawia się wzmianka o „talarach pięciu”, co może sugerować pieśń koniokrada. Ale odczuwamy przede wszystkim ekstatyczność tego tekstu, wyraźną egzaltację (zdrobnienia), która przy braku form osobowych sugeruje monolog dziewczyny, choć to zapewne młody Cygan wyprasza u Boga „ciemna nockę" dla swojego pięknego skradzionego konia. Dodać też trzeba, że w wielu wypadkach zmysłowe tętno piosenek wpisane jest w szczególnie eksponowane paralelizmy, rytmizacje i rymy, a nadto w pojawiajacce się czasem frazy albo zwrotki w języku cygańskim, niezrozumiałe, oczywiście, dla polskiego słuchacza, będące znakiem obcości, lecz także ekwiwalentem jakiejś dzikiej, ciemnej siły z głębokich, pozaracjonalnych pokładów świadomości (np. „Ciumajto - ciumajło”, „De tu dewła, so mangaw”, „Czeni-ridi, czeni-ridi-czara”).

Nie ma wśród piosenek Ficowskiego - w tym zwłaszcza wśród charakteryzowanych tutaj wcześniej piosenek o miłości niecygańskiej, pozostających, co znamienne, w granicach obyczajowej poprawności - tekstów o takim stężeniu ciemnej, ekstatycznej symboliki, jak piosenki „cygańskie”. Jak gdyby (znów) cygańska sceneria stanowiła tu rodzaj alibi dla marzeń i fantazji o wolnej miłości, wypieranych z własnego kulturowego kręgu odbiorcy - mieszkańca PRL-owskich osiedli. Marzeń i fantazji wypieranych, ale przecież nie przestających go fascynować. $N b$. to ciekawy paradoks, bo wiadomo skądinąd, że obyczajowość cygańska w zakresie zachowań seksualnych i relacji: kobieta-mężczyzna, jest w wysokim stopniu restrykcyjna, opisuje szczególnie wiele sytuacji stanowiących źródło skalania, odnoszących się właśnie do tych relacji ${ }^{48}$. To paradoks, a może kolejny dowód na to, w jak niewielkim stopniu piosenki „cygańskie” odwzorowują realia cygańskie, w jakim zaś pisane są w istocie $z$ myślą o nie-Cyganach, o ich nie do końca uświadomionych tęsknotach.

Bo w rzeczy samej, kiedy zastanawiamy się nad realną wartością poznawczą piosenek „cygańskich” Ficowskiego, to odkrywamy, że nie stanowi celu tych utworów jakieś szczególne różnicowanie i pogłębianie obrazu życia cygańskiego. Przeciwnie, tym, co zwraca naszą uwage, jest powtarzalność ujęć, motywów, rekwizytów. Musi to zwłaszcza wydać się nieprzypadkowe $u$ tak wybitnego znawcy kultury i życia cygańskiego, jakim był Ficowski, autor książek Cyganie na polskich drogach, Demony cudzego strachu czy Pod berłem króla pikowego. Sekrety cygańskich wróżb. Nie byłoby dla tego twórcy żadnym problemem ukazanie owego życia cygańskiego $\mathrm{z}$ pełnym realizmem. Tymczasem jednak rządzą $\mathrm{w}$ piosenkach Ficowskiego inne reguły. Wszystkie pojawiające się tam motywy układaja się nie w zbiór obrazów realnego życia cygańskiego, ale w swego rodzaju kod, będący odpowiedzią na tęsknoty odbiorców. Stanowią one figury naszych pragnień, klucze otwierające pewne zakamarki naszej wrażliwości, nie zaś elementy, które komunikują nam jakąś nową wiedzę o cygańskim świecie.

Tak to jest z opisanymi przez Barańczaka motywami drogi, wędrówki, odwołującymi się do pragnienia wolności, a także $z$ motywami lasu, galopu, światła i ciemności, w których dopatrzyć się można symboliki związanej z tłumioną seksualnością. Wreszcie też bardzo wyraźnie widać tę regułę reprezentacji naszych pragnień

Zob. A. Bartos z, Nie bój się Cygana. Na dara Romestar. Wyd. 2, zmien. i rozszerz. Sejny 2004. 
w takiej właściwości świata cygańskiego, którą można nazwać zd olnością do tran sfor m a cji. I znów - nie sposób oprzeć się refleksji, że ta właściwość świata musi mieć charakter alternatywny wobec przeróżnych przymusów i dyktatów rzeczywistości, w tym także tych będących realnością PRL-u. Cóż składa się na ową transformację, baśniowość? Wyrażają ją takie cechy piosenkowego świata „cygańskiego", jak odwracalność (niedefinitywność), zdolność do niewidzialności, magiczne odwoływanie czyjejś władzy, ucieczka w nierzeczywistość, nieproduktywność, magiczne pomnażanie dóbr, budowanie przestrzeni zamkniętej (bezpieczeństwo).

Odwracalność to ta cecha świata cygańskiego, która sprawia, że nie ma w nim sytuacji bez wyjścia, co obserwujemy w piosence Jak zostanę wielka pania:
A jak przyjdzie na nas bieda,
cisawego konia sprzedam,
sprzedam konia, sprzedam tanio
i zostanę wielka panią!
[. . . . . . . . . . . ]
Do namiotu szafę wstawię,
będę mieszkać jak w Warszawie!

Często narzędziem przemiany świata bywa magiczna moc kart. W Bajce o cygańskim królu srogi niegdyś władca zostaje królem karcianym:

\footnotetext{
Aż dziś spotkałem go nareszcie:

$\mathrm{w}$ talii kart siedział jak w areszcie!

Jest królem winnym, winnym bardzo,

ale Cyganki nim nie wzgardzą.
}

Realne strony świata mogą zostać poprawione według karcianych zamawiań, jak w piosence Cztery karty:
W tej kierowej - dadi-daj - wiatr się w lasach zabłąkał, a w treflowej - dadi-daj - złoto rodzi się w strąkach! W tej karowej - dadi-daj - ludzi złych diabli wzięli, a w pikowej - dadi-daj - nie ma nic prócz niedzieli!

W każdej chwili można przepędzić biedę, zamienić gwiazdy w złote kolczyki lub korale, czerpać z nieboskłonu złoto i inne dobra:

Wiozę $\mathrm{z}$ oddali
z gwiazd sznur korali
i tobie, Kali,
złoty księżyc dam.

(Ballada cygańska)

Na wsi jarmark - pójdę tam za kolczyki - gwiazdy dam.

[ . . . . . . . . . ]

A za ćwiartkę gwiazdy znów 
z całej wsi wykupię puch.

Będę z niego mieć pierzyn trzy,

żebym ciepłe miała sny.

(Kolczyki z gwiazd)

Można mieć też suknię z gwiazd: „tylko suknię z gwiazd mi uszyj, / gwiazdy z nieba zerwij sam!" (Czaba-raba-ram), a jesienne liście (w Leśnej Cyganeczce) potrafią zamienić się w złoto:

Opadają liście,

wszędzie jest złociście,

na kolanach dziewcząt złote listki kładzie wiatr.

Świat cygański staje się także miejscem ucieczki od zagrożeń. Dobry las bywa czapką niewidką (Szarika-Marika), a funkcja ogniska jest stwarzanie nieprzekraczalnej zapory, magicznego kręgu światła, który chroni od nieszczęść (Cygańska letnia noc). W kręgu baśniowej, bezproduktywnej zabawy, cygańskiego świętowania, świat jawi się jako bardziej rzeczywisty, substancjalny niż ten znany z realności przymuszającej do pracy. Kluczową rolę odgrywają tu reifikacje i personifikacje bytów niematerialnych, np. muzyki, echa, kolorów, nutek melodii:

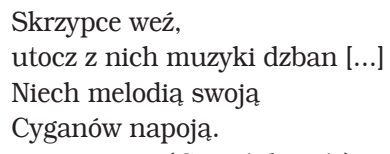

(Cygański wóz)

Komu fiolet, komu błękit,

komu echo tej piosenki,

nim odjedzie $\mathrm{z}$ Cyganami w czarny las?

(Jada wozy kolorowe)

Dwaj Cyganie na polanie grali na cymbałach tamba-diba, tamba-diba, tamba-diba-dam! Jedna nutka-bałamutka od nich odleciała! Wróć z daleka, nie uciekaj nam!

(Nutka-batamutka)

\section{Ballady podwórkowe, czyli sen o Warszawie}

Ma się wrażenie, że o ile piosenki „cygańskie” Ficowskiego przybliżają odbiorcy mocą swej magii - jego niespełnialne marzenia, utopijną szczęśliwość, która jednak gdzieś na granicy świadomości widziana jest przez niego jako nierealna, o tyle piosenki podwórek warszawskich ${ }^{49}$ odbudowują w nim, jak sądzi, pewne wartości

Mam tu na myśli zespół około 20 tekstów Ficowskiego, z których nie wszystkie „dzieją się” na podwórkach w ścisłym sensie, ale wszystkie należą do nurtu parafraz ballad ulicznych. Znanym ich autorem był także m.in. J. J u r a n d ot, a wybitnym miłośnikiem i wykonawcą S. Grze siuk (zob. B. W i e cz orki ew i cz, Warszawskie ballady podwórzowe. Pieśni i piosenki warszawskiej ulicy. Warszawa 1971). W roku 1993 B. B orys-D a mię cka zrealizowała dla TVP 2 program Piosenki ze starego podwórka, w którym zaprezentowano najważniejsze piosenki J. F i c o w s ki e- 
tkwiące w warszawskich duszach od zarania. Pojęcia „warszawska dusza”, „dusza miasta", stanowią zupełnie kluczowe rekwizyty narracji o Warszawie, których autorem stał się krótko po wojnie Leopold Tyrmand ${ }^{50}$. Jego artykuły i felietonowe cykle warszawskie, pełne radosnej afirmacji, czułości dla dźwigającego się $\mathrm{z}$ ruin miasta, utkane są z określeń w rodzaju: „warszawskość tych ulic odurza”, „robi mi się po prostu rzewnie", nawiązuja do postaci Or-Ota, Stefana Godlewskiego czy Czarnej Mańki, niemal bałwochwalcza afirmacja Warszawy obejmuje w tych tekstach dosłownie wszystko, poczynając od tunelu Trasy W-Z i bryły kościoła Świętej Anny, a kończąc na swoistej estetyzacji ruin, m.in. okaleczonych posagów na dachu odnowionego pałacyku Radziwiłłów, które „dają efekt urzekający” i porównane zostają do rzeźby Wenus z Milo.

Ale ów zbiór artykułów Tyrmanda - uświadamiamy to sobie $z$ biegiem lektury - okazuje się najbardziej poruszający nie przez to, co jego autor o Warszawie powiedział, lecz właśnie $z$ powodu tego, czego nie chciał czy nie mógł powi e d zi éc. Albowiem czytelnik współczesny, znający nieco biografię Tyrmanda, poznając jego dziś już historyczne teksty, musi w końcu skonstatować to zasadnicze przemilczenie, które dotknęło tutaj faktu zagłady warszawskich Żydów. Stolica podnosi się $\mathrm{z}$ ruin przy całkowitym braku owego tematu, a Tyrmand - wpisując się w solidna konstrukcję Warszawy sentymentalnej, w mitologię tego miasta, w etos warszawiaka - w swej bardzo osobistej, ukrytej historii jak gdyby odgradza się od tamtej tragedii ${ }^{51}$. Lidia Burska w przenikliwym szkicu o Tyrmandzie stwierdza, że „mitotwórstwo autora Filipa istnieje tylko po to, by zasłonić przed innymi (i sobą?) prawdę zbyt trudną do wypowiedzenia", pisze o bohaterze Filipa:

Czy ta iluzoryczna wspólnota, podobnie jak fason twardego faceta, pozwalała mu łatwiej znieść grozę historii? Czy służyła temu, by ukryć przed światem zniszczoną tożsamość i naprawdę złamaną biografię? ${ }^{52}$

A wreszcie - rozszerzając perspektywę - mówi także o „peerelowskiej metafizyce nieobecności” tkwiącej w literaturze „prawdziwego życia”, w utworach Marka Hłaski i Tyrmanda, budujacych swoje własne mitologie ${ }^{53}$.

go z tego nurtu: Panie, kogo pan uważa, Powracajace piosenki, Szlifierz warszawski, Magiczny cylinder, To nie bajka, Kiedy nie wiesz, co jest grane, Mańka-Desa, Blond Mariola, Zagraj, bracie, temu niebu, Sztajerek na sto dwa, Zostaja nam wspomnienia.

L. Ty r ma nd, Tyrmand warszawski. Teksty niewydane. Warszawa 2011. Książka zawiera dwa cykle felietonów pisarza na temat stolicy (Warszawa 50 i Listy z Warszawy) oraz kilka samodzielnych artykułów. Teksty te publikowane były w latach 1947-1952 i 1956 w „Stolicy”, „Tygodniku Powszechnym” i „Przekroju”.

51 Raz tylko pojawia się wzmianka w opisie ruin Warszawy - o „pustynnych połaciach ghetta” (Ty rm a n d, Tyrmand warszawski, s. 149). Znamienne też, że wśród postaci przedwojennej Warszawy u Tyrmanda nie ma Wiecha, którego opowiadania sprzed 1939 roku, jak ocenia R. Stiller, dotyczyły w jednej trzeciej tematyki żydowskiej (Pót wieku na cenzurowanym, czyli rzecz o Wiechu. Posłowie w: W i e ch [S. W i e c h e c ki i], Mą̇ za tysiąc złotych, czyli Opowiadania żydowskie. Zebrał, oprac. R. Stiller. Wyd. 2, popr. Kraków 2001, s. 290). O przemilczaniu po wojnie zagłady getta warszawskiego zob. m.in.: P. Matyw i e cki, Kamień graniczny. Warszawa 1994, s. 50-56.

52 L. B urs ka, Tyrmand. W zb.: Sporne postaci polskiej literatury wspótczesnej. Kontynuacje. Red.

A. Brodzka, L. Burska. Warszawa 1996, s. 187. 
Tę podwójność Tyrmanda przywołuję tutaj, aby od razu na początku lektury piosenek Ficowskiego o Warszawie $z$ całą siła zdać sobie sprawę $z$ tego, jak łudzące bywają mitologie pisarskie, i aby uodpornić się na ich działanie sentymentalne. Można bowiem powiedzieć, że zawsze tworzeniu mitu, sięganiu po mit, stereotyp, klisze sentymentalne towarzyszy jakaś podskórna intencja, która wyjaśnia, dlaczego w danej chwili taka właśnie klisza staje się użyteczna. W przypadku Tyrmanda, wolno sądzić, budowanie mitologii Warszawy miało bardzo osobisty wymiar. Traumę Tyrmanda, traumę ocalonego, dało się znieczulić gestem przyłączenia się do żyjącej większości, identyfikacji z pewną wspólnotą. Kategoria warszawiaka była autodefinicją zagradzajaca drogę innym, wypieranym tutaj w niebyt samookreśleniom. Stanowiła gest człowieka, pisarza, który - jak stwierdzała Burska o Tyrmandzie - „pragną unieważnić nieprzychylny świat i zastąpić go lepszym; który z odwagą i determinacją starał się zaspokoić największy głód swego życia - głód bycia kim innym" 54 .

A w przypadku Ficowskiego? Jaki sens w latach sześćdziesiątych czy siedemdziesiątych miało sięganie w piosenkach po klisze starej Warszawy? Możemy przypuszczać, w pierwszej chwili tak nam się zdaje, że było to - odmiennie niż u Tyrmanda - przywołanie owych wspólnotowych sentymentów najzupełniej pozbawione podtekstów dramatycznych, że spotkała się tutaj pasja Ficowskiego jako varsavianisty, autora m.in. Wspominków starowarszawskich, z zawsze żywą po stronie publiczności, społeczną potrzebą identyfikacji z rodzinnym miastem, co w sumie stwarzało tak pożądaną dla twórcy piosenek sytuację zaspokajania oczekiwań odbiorczych. Jeśli jednak bliżej przyjrzymy się tej sprawie, to okazać się może, że ani Tyrmand, z własna traumą, nie był tak osobny, ani warszawskie piosenki podwórkowe Ficowskiego nie odwoływały się tylko do niefrasobliwego sentymentu publiczności. Tużpowojenne popularne teksty Tyrmanda o odbudowującej się Warszawie i „duchu” tego miasta, jego dawnych i przedwojennych korzeniach, jakoś wpisywały się przecież w swoistą umowę społeczną niewspominania prawdy o zagładzie getta, która była w pewnym sensie nie do udźwignięcia albo też została wyparta ze świadomości przez pozostających przy życiu. Popularne piosenki Ficowskiego, które wchodziły w obieg wiele lat po wojnie, w czasach późnego Gomułki czy w latach dekady Gierka, również budowały świat zastępczych wzruszeń, świat mitycznej, staroświeckiej Warszawy - tym razem odgradzający od doświadczeń zupełnie współczesnych i urazowych, doświadczeń życia w PRL-u, naznaczonych bolesnymi kompromisami, przystosowaniem się, rezygnacją z wolności.

Coś, co w trybie bolesnej wiwisekcji ujawniała najmłodsza poezja polska $z$ przełomu lat sześćdziesiątych i siedemdziesiątych XX wieku: istnienie sfery szarości, anomii moralnej, frustracji społecznej, piosenka popularna zagospodarowywała w inny sposób, właśnie czując, iż potrzebny jest plaster, by tego rodzaju obolałość dusz uśmierzyć. Skoro zgadzamy się, że głos tej poezji stanowił czytanie realnych społecznych nastrojów, to wolno nam też popularność piosenki podwórkowej - z jej swoistym eskapizmem, połączonym z suflowaniem słuchaczom oczyszczającego poczucia wspólnoty, współudziału w tamtej dawnej tradycji - uznać za solidnie 
zakotwiczoną w realiach społecznych. W istocie rzeczy bowiem w recepcji piosenek warszawskich Ficowskiego chodziło także o ów moment znieczulenia, nałożenie ochronnej, wspólnotowej maski, która dawała szansę nowej konsolidacji zarówno warszawiakowi, jak i „przyjezdnemu”, zarówno „oficjalnemu” ateiście, jak i komuś, komu władza czy ideologia PRL-owska dobierały się do skóry, kto tracił grunt pod nogami i poczucie swojej przynależności.

Stara, przedwojenna Warszawa zostaje w balladach podwórkowych Ficowskiego „nałożona” na tę powojenną, jakby w ten sposób ją unieważniając. Współczesność dotyczy świata owych piosenek jedynie naskórkowo. W istocie trwa Warszawa przedwojenna. Jej typy, charaktery, sceneria - stare, coraz bardziej zaniedbane podwórza, stosunki wewnątrz tych małych społeczności, wolne zawody - szlifierz, skrzypek, dziewczyna uliczna, cieć z miotłą, kominiarz, magik, handlarka starzyzną, kataryniarz, druciarz, a także, choć już tylko we wspomnieniu, żydowski cymbalista $^{55}$. Bohaterka piosenki Blond Mariola żyje wprawdzie już po wojnie, ale jest przecież drugim wcieleniem Czarnej Mańki:

\author{
Czarnej Mańki już nie spotka \\ dziś Czerniaków ani Wola. \\ Dzisiaj nam króluje słodka Blond Mariola.
}

Nieważkość czasu, jaki upłynął, aspekt ciągłości warszawskiego świata zostają podkreślone poprzez błahość tego odwrócenia „Czarna”-,Blond”, bliską właściwie tautologii. Podobnie handlarka starzyzna z piosenki Mańka-Desa, do której imienia tylko „przykleiła się” nazwa powojennych antykwariatów, uosabia tę ciaggłość właśnie, bo przecież jest owa Mańka-Desa całym sercem i wspomnieniami po tamtej stronie czasu, odtwarzając w pamięci:

młodość, która serce grzeje,
siódme niebo, jakich mało,
szczęście, co się zapodziało...
I ten walc Dunaju Fale
wytańczony ile tchu!...

Niektóre ludzkie typy zabłądziły do piosenek wprost sprzed wojny (szlifierz w utworze $Z$ podwórka w podwórko), inne, już w Warszawie po 1945 roku - jakby nic tu się nie zmieniło, albo właściwie na przekór skrzeczącej rzeczywistości PRL-u - powtarzaja dawny styl, sposób na życie, swoje fortunne lub niefortunne przygody (Panie, kogo pan uważa, Taka ryba, Kiedy nie wiesz, co jest grane). Na czym zatem miałaby polegać atrakcyjność i ozdrowieńcza siła piosenek opowiadajacych o nowych wcieleniach przedwojennych bohaterów podwórzowych ballad: o Blond Marioli, której nie dosięgło, jak Czarną Mańkę, ostrze noża zdradzonego kochanka, lecz porzucona została przez perkusistę i przygarnięta przez podwórkowych muzyków; o Mańce-Desie - śniącej o walcach młodości; o szlifierzu - ostrzącym noże i wspominającym klientelę sprzed lat; o współczesnym „frajerze”, który

55 O powojennym trwaniu w Warszawie tych dawnych profesji, scenerii podwórkowych, społeczności kamienic zob. B. Brzostek, Za progiem. Codzienność $w$ przestrzeni publicznej Warszawy lat 1955-1970. Warszawa 2007, s. 47-76. 
„złowił” niechcący żonę w trakcie swoich kawalerskich wypadów nad Wisłę (Taka ryba)?

Rzecz jasna, piosenki te nie odtwarzają etosu przedwojennego apasza - miejskiego rzezimieszka i kochanka ${ }^{56}$. Jako zjawisko historyczne nie był to już raczej wzorzec do kontynuacji, choć pewien etos przynależności do wspólnoty silnie w tych piosenkach występuje. Np. narrator utworu Kiedy nie wiesz, co jest grane chętnie „prostuje” PRL-owskiego frustrata, sztorcując go i przywołując do porządku, do wierności dawnym ideałom:

Trujesz pan, że nie ma Wiecha,

że już świat porzucił nasz,

że na zawsze stąd odjechał...

A ja powiem: stul pan twarz!

Jednak tym, co wydaje się najbardziej, by tak rzec, rewoltujące w piosenkach Ficowskiego, co niosło odbiorcy tych piosenek w latach sześćdziesiątych oraz siedemdziesiątych jakieś tchnienie autentyczności i ozdrowieńczej pociechy, tkwi może najsilniej w nietkniętych przez upływ czasu cechach gatunkowych samej ballady podwórkowej i w jej obrazie świata.

Po pierwsze zatem, pokazano nam tutaj bajkę o świecie wolnym, $\mathrm{z}$ bogactwem zawodów, ról społecznych, losów ludzkich, a więc formułę życia i obraz świata, w którym wolność jest najważniejsza, choć ma swoją cenę: ryzyka, biedy, ale i chwilowych wzlotów i koniunktur. To obraz świata diametralnie inny niż ten, o jakim Osip Mandelsztam pisał: „Żyjemy tu, nie czując pod stopami ziemi [...]” 57 , będący przecież odpryskiem (prawda, że nie tak represyjnym, jak Rosja lat trzydziestych) rzeczywistości Polski powojennej. Mamy tu zatem owe obrazy domokrążnych rzemieślników, artystów, kupców, które można potraktować jako metaforę pewnej utraconej, odebranej pełni życia. Utraconej realności, w której człowiek musiał liczyć sam na siebie i nie wyzbywał się własnego ,ja”, nie cedował swoich wyborów na rzecz kolektywnych organizacji czy ideologii.

Formułą przetrwania jest tutaj właśnie wierność tradycji, wspólnocie stanowiącej bezwarunkowo zbiorowisko indywidualności, o czym mówi piosenka Kiedy nie wiesz, co jest grane:

\author{
Kiedy nie wiesz, co jest grane, \\ kiedy masz kłopoty same, \\ nie mów bracie, że pod fleki wzią cię pech. \\ Nie załamuj się na amen, \\ bo trzymają z tobą sztamę \\ pan Wątróbka i pan Piecyk, \\ Piekutoszczak i pan Wiech.
}

O etosie apasza zob. P. Grochowski, Straszna zbrodnia rodzonej matki. Polskie pieśni nowiniarskie na przełomie XIX i XX wieku. Torun 2010, s. 190-191. W tej książce znajdziemy także charakterystykę gatunku ballady ulicznej, zwanej też podwórzową lub brukową (rozdz. Pieśń nowiniarska a ballada uliczna).

57 O. Mandelszt a m, Żyjemy tu, nie czujacc pod stopami ziemi... W: Poezje. Wybór, oprac., wstęp R. Przybylski. Warszawa 1997, s. 221 (wiersz datowany: „Listopad 1933”; przeł. S. B ar ańczak). 
Chyba większość ballad podwórkowych Ficowskiego stawia w centrum swojego świata pojedyncze działające indywidua, które pchaja przed soba przysłowiowy wózek własnego żywota: poza wspomnianymi Mańka-Desa, Blond Mariola, Szlifierzem warszawskim, takie postacie odnajdujemy m.in. w piosenkach Kominiarczyk, Magiczny cylinder („Był przed laty za magika / teść mój w cyrku numer dwa”), Muzykant-ryzykant, To nie bajka („Znała go Starówka cała, / jak co dzień wygrywał tam / Warszawiankę na cymbałach / stary Mordko Fajerman"), Targ na Mariensztacie („Targ na Mariensztacie, targ na Mariensztacie! / Ech, minęło bracie, jakby z bicza trzasł! / Tutaj rudy Wicek, tu kulawy Maciej / w połatanej szacie szli przez Nowy Zjazd...").

Po wtóre, w balladach Ficowskiego nie czuwa nad odbiorca natrętny moralista, a ich bohaterowie nie okazują się wzorami wszelkich cnót. Przeciwnie, dopadają ich przeróżne słabości, porywczość, pijaństwo i inne pożądliwości, ale też życiowy niefart i bieda czy zwyczajnie - starość. Jest to więc kolekcja losów i charakterów, która nie wpisuje się w żadne schematy ideologiczne, utopie „prawdziwego człowieka”, mieści się na antypodach PRL-owskiej pedagogiki wzorów osobowych, po stronie realnego życia. Piosenki podwórkowe Ficowskiego zawierały ów moment „odpuszczania winy” i także dlatego mieściły się w jakiejś normie alternatywnego świata, świata bez złudzeń, który odnajdywali w nich słuchacze. Można tu zacytować uwagi Roberta Stillera na temat analogicznych kreacji w powojennej prozie Wiecha. Jego obraz „ludku warszawskiego” był okresowo, jak twierdzi Stiller, adresatem unoszacych się w powietrzu, niewypowiedzianych pretensji oficjalnych czynników:

dlaczego ten lud [...] nie awansował na świadomych proletariuszy, coraz to poprawniej mówiących i zajętych przekraczaniem norm w swojej fabryce? Dlaczego to wciąż jakiś lumpenproletariat i drobnomieszczaństwo, jakieś niewyraźne kombinujące polskie szwejki, lenie i pijaczkowie? ${ }^{58}$

Powiedzieć wreszcie trzeba, że warszawskie piosenki Ficowskiego na bardzo elementarnym poziomie konstrukcji świata przedstawionego zdecydowanie sa przeciw wszelkim symbolizacjom. Jeśli zgodzimy się co do tego, iż oficjalny przekaz PRL-owskiej propagandy prezentował świat preparowany, oczyszczany $z$ akcydensu, tak aby można go było wpisać w pewne nadrzędne kategorie ideologii, w porządki symboliczne, to świat piosenek podwórkowych, mający za sobą tradycję tzw. literatury nowiniarskiej ${ }^{59}$, ustanawiał przede wszystkim porządek zdarzeniowy, silnie osadzony właśnie w akcydensach. I to podstawowa cecha tych piosenek, którą dałoby się nazwać odzyskaną naocznościa świata. Nikt nie każe ich odbiorcom poszukiwać sensów symbolicznych ani ich akceptować, mogą oni doznawać wyzwalającej rozkoszy słuchania różnych opowieści, oglądania świata niezhierarchizowanego.

Narrator snuje historie o konkretnych ludziach: Blond Marioli, amantach pan- 
ny Magdy - „Karmelicka osiemnaście” (Szlifierz warszawski), druciarzu, który naprawił pęknięte serce dziewczyny (To nie bajka). Sa to, oczywiście, historie już trochę „spoza czasu”, ze sfery mitu starej Warszawy. Jednak zasada osadzenia opowieści w konkrecie obyczajowym, materialnym obowiązuje. Mańka-Desa oferuje do sprzedaży całkiem realny towar:

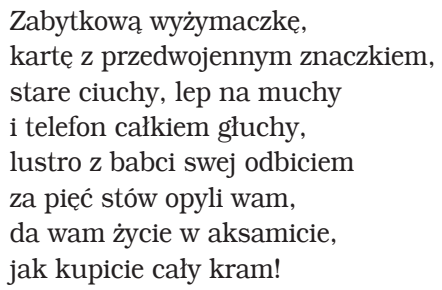

Reguła metonimii, przeciwstawiająca się porządkom symbolicznym, organizuje także balladę Powracajace piosenki, będącą kolekcją „ciepłych miejsc” w pamięci słuchaczy, motywów znanych przedwojennych przebojów (Czemuś o mnie zapomniał, Szkoda twoich łez, dziewczyno, Jesienne róże, Ta ostatnia niedziela, Dziś panna Andzia ma wychodne).

\section{Piosenki patriotyczne i satyryczne - dwa przypadki stłumienia toposów piosenkowych}

Wśród motywów piosenek estradowych Ficowskiego można wskazać nieco rozleglejszą topikę niż ta, o której była dotąd mowa. Nie jest jednak moim celem pełna ewidencja toposów piosenkowych, lecz opisanie wyłącznie tych, które przyniosły żywszy rezonans odbiorczy, co do których należałoby snuć przypuszczenie, że dla ich popularności nieobojętne były realia (nie tylko zreszta polityczne) PRL-u, zrodzone przez te realia tęsknoty czy deficyty emocji, na które owe piosenki stanowiły mniej lub bardziej zamierzoną odpowiedź. Odrębny np. nurt, rzec można: pre - ekologiczny, tworzyły nie związane wyraźnie z kontekstami politycznymi piosenki afirmujące naturę i krajobraz (Co daje deszcz, Taki mały ptak, To chyba maj, Wiatr mieszka $w$ dzikich topolach, Dobra rzeko) czy niosące refleksję o odpowiedzialności ludzi za Ziemię jako nie dające się niczym zastąpić miejsce życia człowieka w Kosmosie (Ballada o niebie i ziemi, Mamy jeden świat). Także i w tym nurcie znalazły się utwory cieszące się popularnością ${ }^{60}$.

Chciałbym jednak teraz skupić się na dwóch jeszcze wątkach tematycznych piosenek Ficowskiego, o tyle ciekawych, że właściwie dane im było pewnego rodzaju niespełnienie, byt wycofany i stłumiony wśród innych dominant tematycznych (piosenek wcześniej tu charakteryzowanych), a powody oraz objawy tego niespełnienia szczególnie mnie tutaj interesują.

Początki piosenkowej aktywności Ficowskiego wiążą się, jak już wspominałem,

60 Utwór wykonywany przez A. G erma n Ballada o niebie i ziemi (muz. R. C z u b a ty), nagrodzony został na Festiwalu Piosenki Polskiej w Opolu w 1973 roku. O popularności tej piosenki, także w ZSRR, pisze piosenkarka w listach do J. Ficowskiego z 14 II 1975 i 3 II 1977 (Korespondencja J. Ficowskiego. Bibl. Ossolineum, Dział Rękopisów, teka G-Gro, nr akcesji 61/79). 
z Państwowym Zespołem Pieśni i Tańca „Mazowsze”. W klasycznym zestawie piosenek „Mazowsza” 61 , będącego swoistą wizytówką PRL-u, poza, oczywiście, głównym nurtem piosenek ludowych (lub powstałych na kanwie utworów ludowych) pojawiaja się trzy niezwykle popularne piosenki patriotyczno-warszawskie współczesnych autorów, z muzyką Tadeusza Sygietyńskiego: Konstantego Ildefonsa Gałczyńskiego Ukochany kraj (1953) ${ }^{62}$, Ludwika Starskiego Jak przygoda, to tylko $w$ Warszawie (1952-1953) ${ }^{63}$ i Jerzego Ficowskiego Polonez warszawski (19541955?). Piosenki te maja korzenie socrealistyczne, ale funkcjonowały także, być może po pewnych korekturach tekstowych, w okresie późniejszego PRL-u, współtworząc - niezależnie od ich wartości artystycznej i wykonawstwa, profesjonalizmu samego „Mazowsza” - swoiste skrzydło patriotyczne i plebejskie oficjalnego decorum propagandowego PRL-u ${ }^{64}$. Można $\mathrm{w}$ przypadku tekstów tych piosenek powiedzieć, że wkomponowują się one w wielką narrację historyczną, która ukazywała powojenną, ludową Polskę jako spełnienie marzeń o szczęściu i sprawiedliwości.

Mówienie zreszta tylko o socrealistycznym rodowodzie Poloneza warszawskiego Ficowskiego byłoby refleksją połowiczną. Chodzi po prostu o to, że utwór ten doskonale wpisuje się, podobnie jak zespół „Mazowsze”, w pewien zestaw klisz funkcjonujących w PRL-u, które organizowały wyobraźnię mieszkańców kraju. Te klisze w groteskowym spiętrzeniu i przemieszaniu ukazuje np. minipowieść Stanisława Dygata Dworzec w Monachium (1973), będąca w tym aspekcie swoista "powtórką z PRL-u”. Jej bohater na różnych etapach życia wchodzi w kolejne role - jest reprezentantem etosu człowieka podziemia okupacyjnego, partyjnym aparatczykiem, prywatnym przedsiębiorcą i Polakiem na emigracji. W jego monachijskim mieszkaniu zaś poniewierają się dywany przeznaczone na handel, portrety Marksa i Lenina, a także płyta z muzyką „Mazowsza”. „Mazowsze” jest lejtmotywem utworu Dygata, pojawia się też, jako swoisty żeton polskości, również na użytek zagranicy, na początku i na końcu tekstu ${ }^{65}$. Filmowa adaptacja Dworca $w$ Monachium nie została u schyłku lat siedemdziesiatych dopuszczona do rozpowszechniania, co świadczy o tym, że hierarchia mitów i klisz, ich właściwe miejsce w wy-

61 Zob. np. wydana w 2000 roku płytę CD Mazowsze. Kukułeczka kuka w serii „Złota Kolekcja. Przeboje 50-lecia" (Pomaton EMI, 7243).

62 Pierwodruk w: K. I. Gałczyński, Poezje. Weryfikacja tekstu N. Gałczyńs ka. Przedm., przypisy A. Stawar. T. 2. Warszawa 1957. Z przypisu redakcyjnego (ibidem, s. 847) dowiadujemy się, że wiersz, stworzony do filmu Piatka z ulicy Barskiej (1953, reż. A. F or d), został odrzucony, a następnie dostał się w ręce Sygietyńskiego, który w ostatnich dniach życia poety skomponował do niego muzykę.

63 Piosenka z socrealistycznej komedii Przygoda na Mariensztacie (1952-1953, reż. L. B u c z kows k i). Zob. A. Pa te k, Starski Ludwik. Hasło w: Polski słownik biograficzny. T. 42, z. 3. Warszawa 2004, s. 369-372.

64 Wczesną analizę tego fenomenu przynosi ciekawa recenzja K. A. Jeleń skie go („Tant pis, ou, ha, ha!” „Kultura” 〈Paryż〉 1954, nr 11) z występów „Mazowsza” w Paryżu w 1954 roku.

65 S. Dy gat, Dworzec w Monachium. Warszawa 1978, s. 6-7: „Wzdłuż hali dworcowej plakaty reklamy: "Cunard Line", mydło "Rexona", Dresdner Bank, Występ "Mazowsza", Puchar NRF: F. C. Bayern - Schalke 04”. Zob. też ibidem, s. 107: „Posłuchaj, Nicole, musisz zatańczyć ze mna Mazura. Czy słyszałaś kiedyś o Młodym Ułanie i o Pannie Krysi? Złapałem ją za rękę i pociągnąłem do adapteru. Poddawała się temu bezwładnie. Szybko, nerwowo nastawiłem płytę i za chwile w trójtapczanowym niemieckim pokoju zabrzmiało "Mazowsze»". 
obraźni społecznej podlegały ochronie czynników państwowych do samego końca PRL-u ${ }^{66}$.

Piosenka Polonez warszawski, której słowa i melodię pamięta się do dzisiaj:

\author{
Chociaż tyle w świecie miast, \\ więcej niż na niebie gwiazd, \\ tu najpiękniej płynie czas, \\ najbliższa sercu jest Warszawa. \\ Nikt już nie odejdzie stąd, \\ drogi jest nam każdy kąt, \\ dzieło naszych serc i rak, \\ nasza duma, nasza sława.
}

- jest, oczywiście, utworem nie do pominięcia w dorobku Ficowskiego ${ }^{67}$. Ale zarazem stanowi ona kontrapunkt dla późniejszych, niezbyt zresztą licznych tekstów, piosenek estradowych, w których, rzec można, autor „wypisuje się” z wielkich narracji historycznych. Gdyby szukać w tych tekstach koncepcji historii naprawdę własnej, mającej trafiać w oczekiwania słuchacza, to byłby to obraz czasu przeszłego jako azylu, jako przestrzeni uspokojonej, nie podlegającej projektom czasu teraźniejszego - czy to w wersji utopii społecznej (jak w socrealizmie), czy tylko państwowotwórczej, integrującej wokół pewnych wartości (np. Ziemie Odzyskane, Zamek Królewski w Warszawie).

Piosenek Ficowskiego w tym drugim stylu jest wprawdzie kilka: Ballada o sztandarze spod Kocka, Opowieść o Królu, To dzięki nim, U nas nad Odrą i Nysa, jednak przeważają takie, które ewokują historię prywatną, rodzinna, sprzed okresu wielkich wstrząsów historycznych, co ma być antidotum na ducha dzisiejszej niwelacji. Powracającym punktem orientacyjnym w niespokojnych czasach sa piosenki, w których dochodzi do głosu swoisty eskapizm rodzinny, przywołuje się świat dziadków i pradziadków, wujków i stryjków, dawne melodie i albumy, choćby w tekście $W$ starym albumie:

$$
\begin{aligned}
& \text { Tutaj nie ma trosk ani cienia, } \\
& \text { tutaj uśmiech sprzed lat się nie zmienia, } \\
& \text { tu nareszcie już nikt nie umiera, } \\
& \text { tu w fontaziach, tużurkach, cwikierach } \\
& \text { hodują czas } \\
& \text { pradziadowie. }
\end{aligned}
$$

Swoista utopia czasu minionego stanowi składnik wrażliwości Ficowskie-

Dygata spotkał przede wszystkim zarzut szargania polskości. Zob. Nie spotykamy się tu dla rozrywki. Stenogram z posiedzenia Komisji Kolaudacyjnej Filmów Fabularnych, $w$ dniu 2 grudnia 1977 roku. „Zapis” (Londyn) 1979, nr 11. Zob. też P. Ka ni e cki, Cień Pałacu Kultury i Nauki. Tadeusz Konwicki o śmierci Wilhelma Macha i Stanisława Dygata. W zb.: PRL - świat (nie)przedstawiony. Red. A. Czyżak, J. Galant, M. Jaw or ski. Poznań 2010.

67 Piosenkę tę wymienia się i udostępnia dzisiaj na internetowych listach „złotych przebojów socjalizmu” (np. http://lubliner.wrzuta.pl/playlista/3K4BMh23p0T/przeboje_socjalizmu /data dostępu: 19 VI 2016)). W przeszłości zaś wielokrotnie była ona przedrukowywana, m.in. w popularnych antologiach pieśni patriotycznych i o Warszawie (zob. Pieśni walki i pokoju. Kraków 1968. - Jest Warszawa. Rewia piosenek o Warszawie. Kraków 1976. - Tobie, Ojczyzno. Wybór pieśni i piosenek. Wybór W. Krodkiewska. Oprac. muz. Z. Ciechan. Red. W. Nał ęcz. Warszawa 1980). 
go bardzo wczesny. Związana jest np. z lektura - już w latach młodości - powieści Dickensa. O jej terapeutycznej funkcji pisze poeta w kontekście wojny, ale i potem Dickens stale jest obecny - w lekturze i twórczości, w tym także w piosenkach (np. Klub Pickwicka, Cywilizowany świerszcz) ${ }^{68}$. Popularność takich piosenek, jak Powracajace walczyki, Świerkowa kolęda, Mój stryjek jest hodowca moli, z muzyką i w interpretacji German, czy Nasz stary dom i Mój wujek Walenty (należących do kręgu rodzinnej, prywatnej opowieści) zdaje się mieć podobnie terapeutyczne źródła.

Piosenkowa historia Polski w tej wersji rodzinno-intymnej stanowi pewnego rodzaju wyparcie historii czy narracji „patriotycznej”, dającej się ideologicznie instrumentalizować. Jej miejsce zajmuje np. historia „pomniejszona” do zabawy w ołowiane żołnierzyki - jak w tekście Mój generał ołowiany, z jego dwuznacznym refrenem:

$$
\begin{aligned}
& \text { Generałom, tym prawdziwym, cześć i chwała! } \\
& \text { Do każdego rzekłbym: generale prowadź! } \\
& \text { Ale dobrze mieć takiego generała, } \\
& \text { którego tak łatwo w kieszeń schować! }
\end{aligned}
$$

A także zabawna „reprywatyzacja” starego motywu w piosence Pra-ułani:

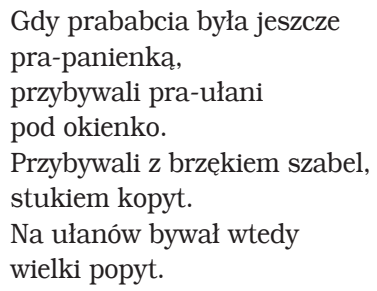

Oczywiście, autor nawiązuje do piosenki Przybyli ułani pod okienko (1914, sł. F. Gwiżdż), zabarwia ją frywolną nutą, a zarazem dokonuje swego rodzaju parafrazującej restytucji klasyki patriotycznej, która w kanonicznej postaci często bywała w PRL ornamentacja przekazu ideologicznego ${ }^{69}$. Podobny charakter, przewrotnie parafrazujący wobec klasyki, ma utwór Panienka z piosenki:

Idzie sobie żołnierz lasem,

bo jest na urlopie.

Zapytała go dziewczyna:

- Dokąd idziesz, chłopie?

O ile wycofywanie się Ficowskiego w krąg historii i ojczyzny „prywatnej” można

Zob. np. J. Fi c o w s k i, Dickens w polskim dyliżansie (2). „Przekrój” 1988, nr 2224, z 24 I, s. 17 : „Sądzę po sobie, zagubionym [...] w okupacyjnej nocy warszawskiej, kiedy po niepokojach i zasadzkach niejednej godziny zsyłał mi [Dickens] dobry, pogodny sen i upewniał o prawie do marzenia, i zapewniał, że istnieje możliwość innego świata, lepszych losów. I zostawiał przy mnie Anioła Stróża z brzuszkiem, łysinką, w kamaszach i okularach, niezrównanego pana Pickwicka”.

69 Pra-ułani śpiewani byli na Festiwalu Piosenki Żołnierskiej w Kołobrzegu w lipcu 1970 (wyk. K. Zdzitowiecka, muz. Z. Ci e cha n). $N b$. na tym samym koncercie wykonano również piosenkę A. Osie ckiej Dzień za dniem. Zob. Program i repertuar koncertów Festiwalu Piosenki Żotnierskiej. Kołobrzeg 1970. 
potraktować jako sposób chronienia i przeżywania tradycji, zabezpieczający tę tradycję przed instrumentalizacją, i uznać za decyzję suwerenną autora, o tyle w przypadku jego piosenek s a ty r y c z n y c h trzeba powiedzieć, że to system PRL zawierał w sobie mechanizmy wypierania tego typu tekstów $\mathrm{z}$ szerszego obiegu.

Nurt satyry politycznej w piosenkach Ficowskiego zaznacza się wyraźnie, choć należy do drugiego planu tej twórczości. Najwcześniejszą bodaj piosenką tego rodzaju był popularny Furman, w 1950 roku wprowadzony do repertuaru zespołu „Mazowsze”, od 1956 roku śpiewany przez Stanisława Jopka (muz. ludowa, w oprac. T. Sygietyńskiego) ${ }^{70}$. Już jesienia 1950 ministerialna Komisja Repertuarowa zdyskwalifikowała tę piosenkę i przez jakiś czas nie była ona przez „Mazowsze” wykonywana ${ }^{71}$. W swoim monologu tytułowy bohater Furmana - „sprawiedliwy [...] woźnica" - ostrzega:

lecz wy, którym rząd oddany, bierzcie za przykład furmany. Wam to należy miarkować, jak podwładnymi kierować.

Wraz z dalszymi zwrotkami - w jednej z nich mowa o tym, że koń „twarde ma kopyta / i jak wierzgnie, to się zdarza, / że dosięgnie gospodarza” - piosenka była entuzjastycznie przyjmowana w różnych latach PRL-u jako aluzyjny komentarz do relacji między władzą a społeczeństwem ${ }^{72}$. Miała także tę zaletę, iż można było stopniować jej wymowę na estradzie, włączając (lub nie) niektóre zwrotki, np. w ramach bisów, a tekst nie ulegał przez to dekompozycji ${ }^{73}$.

Piosenka pochodzi z 1840 roku, „tekst dopisał - doskonale zresztą utrzymując styl piosenki ludowej - Jerzy Ficowski” (T. Kr u k, A. Sroga, „Mazowsze” tańczy i śpiewa. Warszawa 1960, s. 56, 147, 252-254).

71 Zob. ibidem, s. 56. $\mathrm{Nb}$. według relacji Kruka poza piosenką Ficowskiego w repertuarze „Mazowsza” zastrzeżenia Komisji wzbudziła także piosenka Ej, przeleciał ptaszek... Zob. też M. Zi mińs k a - Sygi etyńska, Druga miłość mego życia. Oprac., przypisy M. Sroka. Warszawa 1990, s. 131-133, 322. Z kolei T. Ko ta p s ka, z domu Klimczak (Byłam w „Mazowszu”. Współpr. aut. J. W. C h i m i a k. Warszawa 2001, s. 52-53), również występująca kiedyś w „Mazowszu”, przytacza zapamiętane przez siebie, ocenzurowane fragmenty dwóch innych piosenek: „Oj, powiadają ludzie, że bida umerła, / a ona po wsi hula, oguna zaderła” (tytuł piosenki i autor słów nie podany), czy „Cyraneczka nie ptak / Dziewczyna nie ludzie / Odprowadziłbym ją / Bo sama nie pójdzie” (Cyraneczka, sł. L. Sta r s ki). W tym drugim wypadku zadecydowano, aby zachowujac zwrotkę, zneutralizować jej niewłaściwą wymowę przez dopisanie dwóch dalszych, o dziewczynie-traktorzystce. Zob. rozmowa z E. Ficowską, z 14 I 2011. Zob. też liczne wzmianki o popularności Furmana w wypowiedziach członków „Mazowsza”, m.in. Kruka (w: Kruk, Sroga, op. cit., s. 130, 151, 179, 236), M. Malaszek-Kulfan ow ej (Wspomnienia mazowszanki. Współaut. J. D u b r ow s ki. Warszawa 1965, s. 222), Zi mińs ki ej-Sygi etyńs ki ej (op. cit., s. 292, 305). W pełnej wersji tekst Furmana został opublikowany, jako osobny druk w okresie popaździernikowej liberalizacji, w „Błękitnej Serii” czasopisma „Śpiewamy i Tańczymy” (1958, z. 13), w nakładzie 6 tys. egzemplarzy. Wcześniejsze zeszyty tej serii zawierały ówczesne szlagiery piosenkowe, komponowane w rytmie slow-foxów, fokstrotów, walców, beguine’ów i tang.

73 Widać to na archiwalnych rejestracjach występu Jopka, zamieszczonych w Internecie. O dopisywaniu przez Ficowskiego kolejnych „spiewek” Furmana do już istniejącego utworu świadczy zachowany $\mathrm{w}$ archiwaliach rękopis nowych zwrotek, dołączony przez autora do wspomnianego tu już wydania piosenki:

Gdy szykujesz się do drogi, słuchaj bracie mej przestrogi. 
Opowieść o furmanie stanowi jakby prototyp późniejszych satyrycznych utworów Ficowskiego. W pewnym (stylistycznym) sensie kontynuacją Furmana były niektóre piosenki $z$ cyklu warszawskich ballad podwórkowych, reprezentujące, rzec można, satyrę w stylu p l e b e j s k i m, wykładająca „kawa na ławę” absurdy PRL-u i wywołujacca zdrowy śmiech. Podobnie jak w Furmanie w piosenkach tych mamy do czynienia $z$ mnożeniem przyśpiewek, które w tym wypadku potęują ad absurdum ponury komizm opisywanej rzeczywistości:

Słowo daję, że nie kłamię:

wszystko u nas rośnie fest.

Był ogonek w supersamie,

teraz super-ogon jest.

Ojdyrydy, ojdyrydy - itd.

[. . . . . . . . . ]

W nowym bloku mam mieszkanie,

kaloryfer wisi tam.

Mam centralne zamrażanie

i mrożonkę-żonkę mam.

Ojdyrydy, ojdyrydy - itd.

[. . . . . . . . . . ]

[......... . . ]

Kiedyś w bramie przygrywałem,

nieraz z okna spadł mi grosz.

Dziś złotówka spada na łeb,

spróbuj za nią kupić coś.

Ojdyrydy, ojdyrydy - itd.

(Przyśpiewki warszawskie)

Poszedł teść do sklepu

wiza-wi naprzeciw,

po rybkę mrożoną

lub $\mathrm{z}$ dorsza filecik.

Ale mu personel

grzecznie odpowiedział,

że dziś do sprzedania

ma ucho od śledzia!

Poszedł teść gdzie indziej

i w kolejce stanął,

żeby na zagrychę

wziąć kiszkę kaszaną.

Lecz mu powiedzieli,

Nie pomoże i wędzidło,

jak biczysko koniom zbrzydło!

Zapamiętaj taki-siaki,

coś się dobrze dał we znaki -

choćbyś koniom cukier dawał,

już nie weźmiesz ich na kawał!

Ty, co trzymasz lejce w dłoniach,

już nie zrobisz konia w konia,

jeśli takie masz nadzieje,

to się $z$ ciebie koń uśmieje! (BN) 


\author{
że na razie mają \\ tylko takie kiszki, \\ które marsza grają! \\ (Poszedł teść do sklepu)
}

Trudno ustalić, czy piosenki te - dodać do nich należy także utwór Magiczny cylinder - które pochodza, sądząc $z$,inflacyjnych” realiów, $z$ końca lat siedemdziesiąych, doczekały się estradowego wykonania. Niewiele na to było czasu w krótkim okresie legalnej „Solidarności” przed 13 grudnia $1981^{74}$. Ale Furman, z zawartą w nim paraboliczną konstrukcją, opisującą relacje między woźnicą a koniem, w rzeczywistości zaś między władzą a społeczeństwem, ma także swoją kontynuację w innej grupie piosenek satyrycznych Ficowskiego - posługujących się właśnie stylem parabolicznym, które $\mathrm{z}$ kolei można by nazwać satyrą polityczną należąca do nurtu inteligenckiego.

W okresie popaździernikowej odwilży powstała Ballada o zburzeniu i odbudowie Bastylii (nie całkiem francuska) (1958) ${ }^{75}$. Opisuje ona w kostiumie historycznym zagrożenie nawrotem rządów dyktatorskich, tlącą się już tęsknotę władz do poskromienia rozpasanej wolności:
Więc dumał sobie ten i ów, że chociaż świat się zmienia, te cegły warto zebrać znów, ocalić od zniszczenia.
$[\ldots \ldots \ldots]$
To nie jest przecież byle co - niezłomnych cegieł milion. Choć teraz w pohańbieniu są, wznosiły się Bastylią!

Także wówczas powstała piosenka Przypowieść o stworzeniu świata (1958), w żartobliwym genezyjskim sztafażu przemycająca refleksję o płytkości przemian popaździernikowych:

Lecz co to? Znowu skały hucza!

Grzmot w przepaść toczy się w rozpędzie!

[...] to góra teraz rodzić będzie!

Zadrżało - grzmot uleciał wzwyż -

i góra urodziła mysz ${ }^{76}$.

Podobny charakter miały - powstała w 1959 roku Piosenka z kluczem ${ }^{77} \mathrm{i}$ bar-

Wszystkie trzy piosenki zostały zarejestrowane w ZAiKS-ie w 1982 roku, z muzyką A. Ślu s a r za (Przyśpiewki warszawskie) i S. W i e la n k a (Poszedt teść do sklepu, Magiczny cylinder). W zrealizowanym w 1993 roku programie TVP 2, Piosenki ze starego podwórka (zob. przypis 49), znalazł się tylko Magiczny cylinder (tym razem z muzyką S. Re mb ow s ki e go), zapewne jako piosenka najbardziej stylowa. Czas dwóch pozostałych piosenek po przemianach ustrojowych nieodwołalnie miną. Tekst Ballada o zburzeniu Bastylii (pierwotny tytuł został tu skrócony przez cenzora) zamieszczony był w „Nowej Kulturze” (1958, nr 39, z 28 IX).

Druk: jw. 
dziej metaforyczny Odlot wieszaków ${ }^{78}$, również rozstające się ze złudzeniami zasadniczej demokratyzacji po 1956 roku. $\mathrm{Nb}$. zacytowane tu krótkie fragmenty nie odzwierciedlają całej precyzji i mądrości, $z$ jaką owe ballady wnikały w polityczne meandry i ludzkie dylematy tamtej epoki. Sa one - te utwory - małymi traktatami historiozoficznymi.

Powrót Ficowskiego do pisania piosenek satyrycznych posługujących się parabolą nastąpił na przełomie lat sześćdziesiątych i siedemdziesiątych i znów łatwo w nich odczytać doświadczenia kolejnego „etapu” PRL-u oraz krytycznego fermentu intelektualnego, jaki on zrodził. Jemiołuszkom dobrze u nas (1972) ${ }^{79}$ jest ironiczną transpozycją obyczajów tytułowego ptaszka - dobrze znoszącego mrozy - na realia polityczne PRL-u:

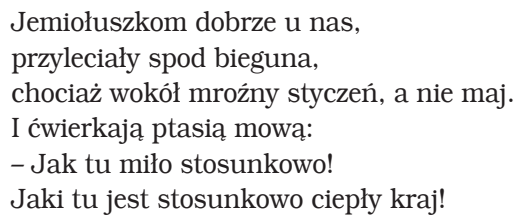

Trzy inne piosenki z tego okresu dotyczyły cenzury i autocenzury, coraz bardziej dewastujących ówczesne życie społeczne:

\footnotetext{
W pewnym mieście w Hondurasie jest wilk, co na sztuce zna się, o czym świadczy fakt, że zjada wiele sztuk $\mathrm{z}$ owczego stada.
}

(Bajka o wilku w Hondurasie, 1968) ${ }^{80}$

Kiedy himalajski masyw informacji cię przygniecie, bierz się za lekturę prasy antidotum masz w gazecie.

Tam nic złego nikt nie powie, wiedzą nie przeciąży nikt cię. I odzyskasz rychło zdrowie na tym dietetycznym wikcie.

(Apologia prasy, 1970) ${ }^{81}$
Wyznałbym, co mam na wątrobie w kilku niezmiernie prostych zdaniach. Lecz za nic tego dziś nie zrobię, bo racja stanu mi zabrania.

Pierwodruk ukazał się jako wiersz w „Nowej Kulturze” 1958, nr 51/52, z 21/28 XII, następnie w tomiku J. Fi c o w s ki e go Amulety i definicje (Warszawa 1960), w roku 1970 utwór przerobiony został przez autora na wersje piosenkowa (rymowana) i opublikowany w „Szpilkach” (1970, nr 13, z 29 III). Druk: „Szpilki” 1981, nr 14, z 5 IV. Druk: jw., 1980, nr 47, z 23 XI. Nietrudno tu rozpoznać aluzję do praktyk cenzury w okresie Marca 1968.

81 Druk: jw., 1971, nr 24, z 13 VI. 
$[\ldots \ldots \ldots \ldots$

Ominę fotel wywyższony i panegiryk śląc mu gładki, będę znieważał puste trony, z których wczorajsze wstały zadki.

(Niezastapione imperfectum, 1971) ${ }^{82}$

Losy piosenek Ficowskiego $\mathrm{z}$ nurtu satyry politycznej najbardziej odbiegały od karier jego typowych piosenek estradowych i, oczywiście, wynikało to $\mathrm{z}$ istnienia cenzury. Jeśli zatem mówię tu o owym kolejnym „stłumionym” temacie piosenkowym, to mam na myśli fakt, że obecność cenzury w tym wypadku uderzała najmocniej właśnie w atrybuty piosenkowe owych tekstów. Nietrudno zauważyć, śledząc ich funkcjonowanie na tle pozostałych utworów, że otaczała je jakaś pustka wykonawcza. Niewiele $z$ tych piosenek zawiera w zachowanych egzemplarzach informację o kompozytorze muzyki (występuje ona w większości maszynopisów innych tekstów) ${ }^{83}$. Nie kojarzą się owe utwory z nazwiskami znanych wykonawców - jak w przypadku piosenek miłosnych (German, Santor, Zaucha), „cygańskich” (Burano, Randia, Rodowicz) czy ballad podwórkowych (Stępowski, Połomski).

Jedynie Ballada o zburzeniu Bastylii, pod tak właśnie skróconym tytułem, śpiewana była przez Andrzeja Szczepkowskiego w programie odwilżowego kabaretu Pod Ponckim Piłatem, na przełomie lat 1958-1959 występującego gościnnie na scenie Studenckiego Teatru Satyryków (STS) w Warszawie. Program został także wyemitowany w TV jako Teatrzyk Telewizyjny „Pod Piłatem” ${ }^{84}$. Joanna Kulmowa tak wspomina tamto wydarzenie artystyczne:

Kabaret „Pod Ponckim Piłatem” wymyśliliśmy sobie w trójkę z [Jerzym Ficowskim i] satyrykiem Jerzym Kleynym, pozbieraliśmy paru znajomych aktorów, co nie było specjalnie trudne, bo kończyłam wtedy wydział reżyserski Szkoły Teatralnej. Salę wyżebraliśmy od STS-u, mam jeszcze zdjęcie widowni z roześmianymi widzami (Hanką Bielicką, Duszyńskim). Pierwszy i ostatni program nosił tytuł Jakoimy (...odpuszczamy naszym winowajcom...) i był nieco bezbożny: Siemion był tam Abrahamem, targującym się z Bogiem o Sodomę i Gomorę, Barbara Krafftówna przypominała księżom swoje grzeszne zasługi, no a Szczepkowski śpiewał o zburzeniu Bastylii. Jakiś czas później powtórzenie tego programu poszło w Telewizji i chyba wtedy Ficowski dopisał też uroczą piosenkę o słowiku ${ }^{85}$.

Druk: jw., 1980, nr 47, z 23 XI.

Dwa tylko maszynopisy piosenek satyrycznych - Kobytka u ptota (1969) i Tempora mutantur (1970) - odnotowują nazwisko kompozytora (W. Ko r c z), i tylko one zarejestrowane zostały w ZAiKS-ie. Oba utwory ukazały się drukiem w „Szpilkach”, pierwszy w 1970 roku (nr 13, z 29 III), drugi zaś w 1971 roku (nr 34, z 22 VIII), ze zmienioną końcówką deklinacyjną: Kobytka u płotu.

Zob. Jakoity, Jakoimy, Jakoiwy... „Antena” 1958, nr 7/8, s. 30-31 (z tekstami z programu, m.in. z Ballada o Bastylii J. Ficowskiego). - Cztowiek Pogranicza. Z J. Ficowskim rozmawia M. Le b e c k a (2001). W zb.: Wcielenia Jerzego Ficowskiego, s. 705. Fakt wykonania ballady przez A. Szczepkowskiego odnotowano także przy jej tekście publikowanym w „Nowej Kulturze” (1958, nr 39, z 28 IX) - zob. przypis 75.

J. Kulmow a, list do J. Kandziory, z 10 XII 2012. Słowo „Jakoimy” pochodzące z tytułu - śpiewane w spektaklu z akcentem na ,i” - stawało się personifikacją (powtarzała się fraza „Wszystkiemu winny Jakoimy”, z dopowiedzeniem w tle „odpuszczamy naszym winowajcom”). Wzmiankowana w liście druga piosenka J. Ficowskiego to utwór o charakterze lirycznym $O$ słowiku $w$ tonacji gwizd-dur, z muzyką W. Sz pilma na. 
Można chyba powiedzieć, że cenzura, najsilniej godząc w swobodny, społeczny obieg utworów satyrycznych Ficowskiego, zepchnęła je ze sfery piosenkowości do niemal czystej poetyckości. Wymusiła na nich byt tekstowy, kanonizujący i zastygający w jednorazowym przekazie - tylko drukowanym. Jedyną przecież możliwość ich upublicznienia przynosiły nieliczne momenty „odwilży” i prezentacja czasopismiennicza. Spektakl Jakoimy z Ballada o zburzeniu i odbudowie Bastylii był tu wyjątkiem potwierdzającym regułe. Niektóre $z$ piosenek satyrycznych czekały na sposobność druku ponad 10 lat! ${ }^{86}$ Można przypuszczać, że im bardziej niepewny stawał się byt owych utworów jako piosenek, tym usilniej Ficowski starał się przeciwdziałać ich rozproszeniu, wszystkie zaopatrywał w daty powstania, kierował do druku, gdy tylko klimat polityczny na to pozwalał, planował też zebranie ich oraz prezentację estradowa - w postaci cyklu Nie do śmiechu, złożonego z 10 utworów i zawierającego w maszynopisie adnotację: „teksty Jerzego Ficowskiego do satyrycznego programu poetycko-muzycznego" (BN) ${ }^{87}$.

Nie od rzeczy będzie jednak zauważyć, iż osobliwy status owych piosenek-wierszy wynikał nie tylko $z$ działania cenzury, ale też - choć w dużo mniejszym stopniu - $z$ ich wymagającej, parabolicznej poetyki. $Z$ tego, że posługiwały się wielką metafora, mową ezopową, eufemizmem. W taki wybór (i poniekąd przymus) estetyczny wpisany został pewien paradoks, od którego wolne były klasyczne piosenki estradowe, odwołujące się do masowej wyobraźni i tu lokujące swą ofertę. Otóż narrator ballad satyrycznych odpowiadał na powszechną tęsknotę do wolności, do prawdy o PRL-u, a równocześnie stawiał się - jako krytyk zjawisk społecznych, analityk procesów historycznych, jako mistrz aluzji i poetyckiego kryptonimowania - ponad oczekująca prostych przekazów publicznością piosenkową.

Także $\mathrm{z}$ takich względów utwory te - jako wyparte $\mathrm{z}$ nurtu stricte piosenkowego - sytuują się gdzieś w połowie drogi między piosenką a poezją. $Z$ jednej strony, wpisują się w model zaangażowanej piosenki poetyckiej, tej spod znaku STS-u, nieco później klubu Hybrydy, kabaretów Dudek czy Pod Egida, pokrewne są tekstom Wojciecha Młynarskiego, w mniejszym stopniu Jonasza Kofty i Agnieszki Osieckiej ${ }^{88}$. A zarazem zbliżają się do ściśle poetyckiego bieguna twórczości samego Ficowskiego. Bieguna wierszy satyrycznych, rozrachunkowych, tych zebranych przede wszystkim w tomach Gryps (1978) i Errata (1981), które operują bardzo już zwar-

Tak było np. z tekstem Bajka o wilku $w$ Hondurasie z 1968 roku. Redaktor „Szpilek”, K. T. To eplitz, pisał w liście do J. Ficowskiego (z 11 XI 1970. BN), w odpowiedzi na propozycję druku utworu: „Pańską Bajka o wilku $w$ Hondurasie ubawiliśmy się setnie, ale, jak Pan zresztą przewidywał, nie wydaje mi się, abym mógł ją w tej formie wydrukować. Podkreślam, że w tej for $m$ i e, ponieważ, na mój nos, fragmentem "inkryminowanym" może być ów fragment o "obiektach przemysłowych", który pozwoliłem sobie zaznaczyć na Pańskim rękopisie. Jeśli by Pan miał ochotę coś tu przeinaczyć - gotów bym był spróbować druku, oczywiście bez gwarancji, czy mi się to uda”. Ostatecznie tekst ukazał się w „Szpilkach” dopiero 10 lat później, w listopadzie 1980 (zob. przypis 80 ).

87 Na cykl ten, oprawiony w osobnej zszywce, składają się następujące piosenki: Odlot wieszaków, Apologia prasy, Zaproszenie do nieśmiertelności, Niezastapione imperfectum, Tempora mutantur, Kobytka u płota, Jemiołuszkom dobrze u nas, Ballada o zburzeniu i odbudowie Bastylii (nie całkiem francuska), Stworzenie świata i - odnaleziona w innym miejscu teczki - Piosenka z kluczem.

Zob. P. D e rlatka, Poeci piosenki 1956-1989. Agnieszka Osiecka, Jeremi Przybora, Wojciech Młynarski i Jonasz Kofta. Poznań 2012. 
tym węzłem poetyckiego słowa i składni - daleko im do rymów piosenkowych i jednocześnie intensywnie oddychają czasem historycznym.

\section{W stronę piosenkowej retoryki}

Tajemnica popularności piosenek Ficowskiego, jak zresztą w ogóle piosenek estradowych, wiąże się przede wszystkim $z$ wkraczaniem na obszary tematyczne szczególnie oczekiwane przez słuchaczy, polega na zaspokajaniu powszechnych tęsknot, wypowiadaniu - często peryfrastycznie czy nawet językiem symboli - oczekiwań i treści wypieranych do sfery podświadomości, na budowaniu światów czy obszarów wyobraźni będących chwilowym azylem względem świata realnego, z którym boryka się odbiorca. Piosenka jednak stanowi zarazem wielokodowy, muzyczno-słowny przekaz odznaczający się totalnością oddziaływania. Chciałbym zatem teraz zająć się fenomenem odbioru przekazu piosenkowego, postarać się odpowiedzieć na pytanie, w jaki sposób, w stosunku do równoległej linii muzycznej, melodyczno-rytmicznej, wpływającej na emocje odbiorcy, buduje się przekaz słowny. Przekaz - podkreślamy od razu - krótki i sugestywny, który charakteryzować się musi szczególną siłą oddziaływania - jako niosący swoją opowieść, jako tworzący z muzyką pewne iunctim emocjonalne, a zarazem walczący o własną (i całej piosenki) odrębność, zrozumiałość, atrakcyjność.

Potrzeba u sły s z e n i a tekstu wydaje się kluczowa jako element towarzyszący konstrukcji piosenki. Pytanie - jak tekst walczy o swoje zaistnienie, jak w krótkim momencie, osadzonym w emocjonalnej dynamice przekazu muzycznego, dąży on do związania uwagi słuchacza - stanowi dla mnie podstawowa przesłankę analizy warstwy słownej utworów piosenkowych Ficowskiego. Wchodzę tu w paradoksalną polemikę $z$ ustaleniami Anny Barańczak ${ }^{89}$, która z tych samych przesłanek - skonstatowania naporu muzyki na tekst piosenkowy - wysnuła wniosek odmienny od mojego: iż z tego właśnie powodu tekst ów ma naturalną skłonność do banalizacji i zamykania się w sferze utartych, łatwo przyswajalnych formuł słownych i poznawczych. Nie miejsce tu na szersze rozważania teoretyczne, jednak wydaje mi się, że tamta teoria, w intencji swej nobilitująca popularną piosenkę jako przedmiot dociekań literaturoznawczych, równocześnie jakby nie doceniła autonomii tego gatunku. Widziała go w porządku poezji, osadzała w strukturalistycznej koncepcji języka poetyckiego, jako pewnego idealnego systemu generowania znaczeń i polifonii, który ulega w piosence uwstecznieniu, redukcji pod naporem muzyki.

Doceniając nowatorski charakter książki Anny Barańczak, trzeba jednak powiedzieć, że w konsekwencji takiego myślenia o piosence tekst piosenkowy jawił się jako gorsza odmiana poezji, jedyną zaś szansę na jego wybitność stanowiło zbliżanie się do ambitnej liryki. Najwyższą notę autorki uzyskało wówczas tylko kilka znanych piosenek autorstwa świetnych poetów, i to one, jej zdaniem, wytyczały pożądany kierunek ewolucji polskiej piosenki ${ }^{90}$.

Proces krystalizacji piosenki widziałbym w zupełnie innym świetle - jako wysiłek przełożenia świata na proste kategorie, jednakże w taki sposób wyrażone, aby 
cechowały się szczególną dobitnością i intensywnością. Chciałbym się tu odwołać do pojęcia konceptu, które ma, oczywiście, odniesienia do poezji, zwłaszcza barokowej, jednak - jako oznaczające pewien gest retoryczny - może być też zaadaptowane do rozważań o piosence. Stanisław Barańczak w inspirującej, jak pisze, „wycieczce komparatystycznej” we wstępie do swojej Antologii angielskiej poezji metafizycznej XVII stulecia powiada, że „koncept zawiera w sobie zarówno sprzeczność jak pokrewieństwo pojęć, zarówno niepodobieństwo jak i analogię", a następnie cytuje Helen Gardner, która stwierdza, iż celem konceptu ,jest sprawić, abyśmy, podziwiając pomysłowość (porównania), jednocześnie uznali jego słuszność” ${ }^{91}$. Idąc do pewnego stopnia za tą formuła, w przypadku kon ceptu piosenkowe go położyłbym jednak nacisk na aspekt pragmatyczny i percepcyjny, na kondensację świata, nadawanie mu wzmożonej wyrazistości w tekście słownym piosenki poprzez eksponowanie dwóch jego cech najważniejszych - oczywistości i niezwykłości - które powstrzymywać będą napór strumienia muzyki, dążącego do zdominowania percepcji utworu.

W istocie właśnie przypadek Ficowskiego, jako autora tekstów piosenek, najlepiej ilustruje swoistość języka piosenki. Praca bowiem tego twórcy nad piosenkami, praca tekściarza, motywowana - jak to już wcześniej podkreślałem - względami zarobkowymi, polegała na uaktywnieniu odmiennych niż poetyckie dyspozycji pisarskich, na sięgnięciu po zupełnie inne pióro, które, jak twierdził, nie było piórem poety. Pytanie: jak dalece rzemiosło poetyckie ułatwiało Ficowskiemu pracę nad piosenkami, jak bardzo zaś musiał on przezwyciężać odruchy poetyckie, aby napisać dobrą piosenkę, nie uzyska tutaj, być może, zadowalającej odpowiedzi. Zamierzam, rzecz jasna, odnotowywać pewne tropy poezji wysokiej Ficowskiego, które trafiły do jego piosenek. Jednak, po pierwsze, silnie chcę podkreślić - uprzedzając dalszą część mojego wywodu - że te wysokie poetyckie ingrediencje zostają przez autora Wozów kolorowych, z całą świadomością rzemiosła piosenkowego, powściagnięte, zredukowane, poddane swoistej homogenizacji i, po wtóre, że sama zasada konceptu piosenkowego - jako dążącego do pogodzenia oryginalności z oczywistościa - jest w istocie przeciwieństwem wysokiej poezji, zatem w samym ognisku konceptualizacji piosenki nie będą owe ingrediencje pełniły zasadniczej funkcji.

Widzimy więc, że kreacja piosenki estradowej rozgrywa się w sferze konceptu. Podkreślmy, chodzi o takie nazwanie, opisanie, wypowiedzenie świata piosenkowego, które cechować się będzie jednocześnie oczywistością i elementem zaskoczenia, oryginalności, a zatem czymś, co zdoła związać uwagę słuchacza - będącego przecież człowiekiem „Z ulicy”, nie mającym kompetencji czytelnika poezji - i łatwo pozwoli mu ogarnąc sytuacyjnie, metaforycznie, językowo przesłanie piosenki. Jakiś prototyp, praformę konceptu piosenkowego stanowi, rzecz jasna, s z l a g w o r t, oznaczający sekwencję słów, która winna wbić się w świadomość odbiorcy danej piosenki. Ten termin, tak bezpośrednio wywiedziony z praktyki tekściarsko-kompozytorskiej, świetnie nam potwierdza sytuacyjną, retoryczną, nie zaś poetycką genezę tekstu piosenkowego.

91 S. Barańczak, wstęp w zb.: Antologia angielskiej poezji metafizycznej XVII stulecia. Wybór, przekł., wstęp, oprac. ... Warszawa 1982, s. 10. 
Najczerwieńszy kwiat, czyli koncepty substancjalne

Przechodząc do refleksji nad poszczególnymi obszarami krystalizacji tekstowej piosenek Ficowskiego, owymi konceptami, które dramatyzują utwór, nadają mu oblicze własne, rozpoznawalność, nie zmuszając przecież słuchacza do niewykonalnej „lektury” tekstu (tej przeprowadzanej przez czytelnika poezji), możemy więc najpierw wskazać na „kotwiczący” uwagę odbiorcy w świecie piosenki - k o n c e p t substancjalny, intensywne wypełnienie tekstu wyrazista materią i jej transformacjami. W grupie piosenek, w których silny jest ten rodzaj piosenkowej narracji, żywe są np. takie materie i żywioły świata, jak bursztyn, woda (deszcz, rzeka), wiatr, tęcza, części ciała, kwiat (róża). Wypełniaja one w całości „kadr” piosenki, po czym podlegaja niejako przemianie, ekstrapolacji, ich semantyka przenosi się w prosty sposób w sferę pewnego uogólnienia, reguły świata, życia. Ów pierwiastek materialny ulokowany zostaje wówczas w jakiejś regule mądrościowej (np. miłość jak róża odradza się kolejnego lata) czy mimetycznej (np. rzeka podobna jest do odchodzącej dziewczyny), której trafność wydaje się tyleż zaskakująca (intrygująca), co narzucająca się swoją oczywistością. I na tym kończy się w wypadku owego konceptu przekaz piosenkowy.

Koncept substancjalny operuje więc obrazem, a jednocześnie analogia, ale nie zamierzam tutaj używać terminu „metafora”, ponieważ zarówno materia (substancja), jak i nadbudowana nad nią mądrość, reguła - składające się na koncept - mają w piosence status względnie autonomiczny. Autonomia obu składników jest sprawą podstawową. Słuchacz piosenki musi przede wszystkim odczytać komunikat obrazowy, uznać go za niepodważalną realność. W centrum piosenki Bursztynu okruch złoty znajduje się tytułowy kawałek bursztynu, wokół którego z wolna buduje się łańcuch konotacji: to talizman „na miłość, od tęsknoty”, ponieważ „zostawi tylko uśmiech”, pojawia się „po burzy już, po wichrze złym, po sztormie, / po niegościnnych dniach”, a chwila spotkania „w pamięci jak w bursztynie / zostawi złoty blask”. Bursztyn ocali nas, ponieważ stanowi „dar siódmej fali” i „będzie z niego pierścień / zaręczynowy”.

Według podobnego konceptu zbudował Ficowski wiele innych swoich piosenek. Róża wiąże się na zasadzie kontrastu i analogii z postacią „czarnej [...] dziewczyny”. Jest kłująca, ale i oddana, przemija, odchodzi jak dziewczyna, ale też powraca, i tak jak ona „zakwitnie w środku lata” (Najczerwieńszy kwiat). Deszcz inicjuje flirt, bohater piosenki zwraca się do kobiety: z kół na wodzie „zrobię [...] tobie / tysiąc bransolet”, „zanim deszcz do naszych okien się dodzwoni, / pocałujmy się pod daszkiem naszych dłoni!" (Co daje deszcz). W Cygańskiej podkowie podkowa gromadzi wokół siebie kilka wątków: wywołuje tęsknotę za włóczęgą, rodzi pytanie, czy przełamana może obdzielić szczęściem drugą osobę, ukochanego?, zawiera odpowiedź na to pytanie, jaką jest odejście chłopca:

\footnotetext{
Szczęścia wzięliśmy po trosze na wędrówki, na szalone. Chłopiec w jedną stronę poszedł, a ja poszłam w drugą stronę.
}

Rzeka stanowi praformę ludzkich kształtów i zachowań w piosence Naga rzeka. Wpisana jest w nią logika, paradoks odchodzenia i trwania przy sobie zakochanych: 
„I rozstanie obiecujesz mi bez końca, / i zostajesz, najwierniejsza i milcząca”. Ciato dziewczyny, jej suknia, powtarzają tylko urodę nurtu:

Byłaś naga.

A ubrałaś się w szum klonu.

Powłóczyście ci w tej sukni i zielono.

Jak widać, koncepty substancjalne oznaczają wprowadzenie do piosenki łatwo percypowanego motywu przewodniego, a następnie oparcie na nim pewnej reguły świata. Jest tak, jakby materia, substancja, żywioł stanowiły probierz trwałości i niezmienności owej reguły, a zarazem gra toczy się o świeżość i trafność asocjacji, jakie ten skrawek realności generuje. Ostatecznie zatem odbiorca piosenki - i taki jest chyba podstawowy efekt konceptu substancjalnego - utwierdzony zostaje w najogólniejszej harmonii świata.

\section{„[...] przez głupich łez powiększajace szkło”, czyli koncepty pejzażu duchowego}

Oczywiście, także w przypadku takich konceptów cel piosenkowej konstrukcji retorycznej stanowi zaintrygowanie odbiorcy i wyrazistość przekazu słownego. Tym razem jednak już nie „twarda” empiria, substancjalność przedmiotów czy żywiołów (zwłaszcza wody) będzie centrum krystalizacji piosenki, źródłem swoistej sentencjonalności, ale ludzkie doświadczenia zostaną opisane językiem pejzażu, obrazów natury, ewidentnie podporzadkowanych ekspresji ludzkiego wnętrza. Chodzi $z$ reguły o uzyskanie efektu niezwykłości, o operowanie krajobrazem jako figuracja ludzkich uczuć, co, oczywiście, zasadniczo zmienia proporcje świata, i nie jest już, jak to się działo w przypadku konceptów substancjalnych, wpisywaniem ludzkich doświadczeń w nadrzędną logikę materii, naturalnych żywiołów. W tej grupie piosenek to czyjeś ,ja”, jego uczucia, marzenia, stanowia wzorzec, który przekształca świat, pejzaż, czyniąc go „tekstem”, echem, zwierciadłem duszy, lęków, uniesień, zamyśleń.

Miłość potrafi przemówić obrazem dwóch księżyców, jak gdyby za jej sprawą zrodziły się anomalia w sklepieniu niebieskim. Taki jest właśnie koncept piosenki Dwa księżyce, jedna noc. Nie od razu zaczynamy domyślać się, że księżyc odbija się tu w dwóch źrenicach wpatrzonych w siebie zakochanych lub może dwoi się im w oczach za sprawą afektu miłosnego:

$$
\begin{aligned}
& \text { A stary księżyc - cóż ma począć } \\
& \text { z wyblakła już srebrną tarczą? } \\
& \text { Już go nie trzeba naszym oczom, } \\
& \text { nam dwa księżyce wystarczą. }
\end{aligned}
$$

W innej piosence - Noc i dzień (Boćkoryca) - następstwem dnia i nocy rządzą nie obroty Ziemi, ale spojrzenia w źrenice ukochanej i uśmiechy: 
Mam w uśmiechu moim na dnie

[.............. . ]

blask, co noc rozświeci ładnie.

Oczy zresztą są w tych przekształceniach świata, deformacjach, przybliżeniach, oddaleniach, dyktowanych subiektywnym stanem emocji, organem kluczowym, także filtrem i transfokatorem obrazów pamięci, jak w refrenie piosenki - Więc nie dziw się - o wygasłej miłości:

\footnotetext{
Więc nie dziw się, że nieraz niespodzianie dalekie dni, zasnute czasu mgła, przesłonią świat, gdy znów popatrzę na nie przez głupich łez powiększające szkło.
}

Najbardziej charakterystyczne przykłady zaburzenia przestrzeni pojawiają się w kilku piosenkach Ficowskiego o zawiedzionej miłości, gdzie nieobecność ukochanego, tęsknota, niejako anihilują świat i zawieszaja prawa fizyki. W piosence Spalony most świat po rozstaniu przypomina wojenne zgliszcza:

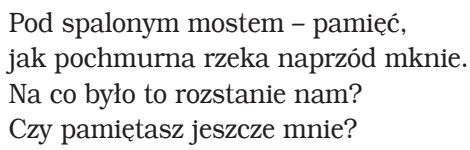

Groza niemal końca świata uderza w piosence O-lejli-hej, gdzie miłosne niespełnienie przekłada się na swoistą przestrzeń negatywną:

Droga nie biegnie, góra nie stoi,

nic nie ma oprócz tęsknoty mojej.

Ukochany był całym światem również dla bohaterki piosenki Bez ciebie nie ma mnie, przy nim „biegły wszystkie drogi / jak wierne psy”, dla niego „świat się zielenił... / A teraz pusto w całym niebie, / na całej ziemi!” Przede wszystkim zaś, kiedy odszedł ukochany, z dziewczyny także uchodzi życie. Tylko on może odwrócić ten stan:

I w radość powitań zamień

smutną legendę.

A wtedy nic nas nie okłamie, bo znowu będę!

\section{Kawiarenka na Piwnej, czyli koncepty przestrzeni \\ i czasu zamkniętego}

Na drugim biegunie w stosunku do piosenek dramatyzujących świat i ukazujących go „przez głupich łez powiększające szkło” znajdują się utwory, które zyskują sobie słuchacza dzięki obrazowi świata uspokojonego, wolnego od zagrożeń, pomniejszonego. To szereg tekstów budujących wrażenie oddalenia od spraw współczesnych, zamknięcia, zarówno w czasie, jak w przestrzeni. W istocie więc mamy do czynienia z dwoma konceptami- przestrzeni zamkniętej i czasu zamkniętego. Także i one przeważnie występują w piosenkach o tematyce miłosnej, a owo 
zamknięcie oznacza często właśnie przywołanie minionego uczucia. Kawiarenka na Piwnej odtwarza ciepłe miejsce w pamięci, zarazem utracone i niezmienne. Nie da się odzyskać tamtej miłości, pochopnie zagubionej, ale także wymazać jej ze wspomnień:

Dni wczorajszych opadanie -
porywisty czas - jak wiatr...
Ale gdzieś tam pozostanie
zagubiona pośród dat
kawiarenka na Piwnej.

W piosence Najwierniejsze wspomnienie przestrzeń kawiarni zastąpiona zostaje kadrem fotografii:

\author{
Najwierniejsze wspomnienie \\ drzemie wśród fotografii \\ i zasuszone jak liść \\ już zasmucić mnie dziś \\ nie potrafi.
}

Podobnie jak „schowki” w czasie - działają także przestrzenie najczęściej ogarniające zakochanych i rysujące obszar wyosobnienia, bezpieczeństwa, intymności: noc (Nas dwoje, Noc kastylijska), deszcz (Poprośmy o deszcz), sen (Sny moje i twoje), ognisko (Cygańska letnia noc), uliczka (Znajoma uliczka) czy owa kawiarenka na Piwnej.

Fotografia z piosenki Najwierniejsze wspomnienie podsuwa wszakże jeszcze jeden aspekt wyosobnienia w czasie i przestrzeni, pewien rodzaj ikoniczności, który jest też źródłem swoistego pocieszenia, uśmierzenia współczesnych lęków słuchacza piosenek Ficowskiego. Należałoby tu odwrócić metaforę - „głupich łez powiększające szkło" - i przywołać raczej obraz widziany przez okular odwróconej lornetki, a więc obraz pomniejszony i dający poczucie kojącego oddalenia. Wspomniałem przy innej okazji, że tak właśnie jest w piosenkach Ficowskiego o historii, kiedy przeszłość ogląda się przez pryzmat domowych albumów i kiedy buduje się rodzaj utopii czasu przeszłego. Oczywiście, pojęcie starej fotografii należy tu rozumieć bardzo dosłownie, jak w piosenkach $W$ starym albumie czy Rupiecie (gdzie mowa o „pożółkłych latach”). Ale ikoniczność - nadająca światu piosenki „ramkę” czasu i przestrzeni zamkniętej, uspokojonej - nie musi zostać nazwana wprost, aby była odebrana przez słuchacza.

Mam tu na myśli odnawianie przez piosenkę - ikoniczności przechowywanej w pamięci zbiorowej, nietożsamej z pamięcią prywatną. Dzieje się tak w utworach w rodzaju Pra-ułani, Panienka z piosenki, A jak będa maszerować, gdzie obok cytatów muzyczno-tekstowych nawet średnio wykształcony odbiorca dostrzeże sceny z polskiej ikonografii narodowej w stylu Kossaków, popularyzowanej m.in. na pocztówkach z przełomu XIX i XX wieku. Równie głęboko sięgają w podświadomą pamięć obrazów niektóre piosenki „cygańskie”, opowiastki czy scenki z udziałem Cygana z fajka (Byle ładny był dzień), baby i Cygana (Tam za lasem), dwóch Cyganów cymbalistów (Nutka bałamutka), cygańskiego króla (Bajka o cygańskim królu), Cygana i jego konia (Czarna noc i biały koń), Cygana i Cyganki (Poszedt Cygan góra). Piosenki te sa najmocniej zakotwiczone w polskiej tradycji literackiej i ikonograficznej, w niezmiernie żywej dla Ficowskiego XIX-wiecznej tradycji stu- 
diów warstw społecznych, ich przedstawicieli, posługującej się poetyką o b ra z k a i powstałej w epoce międzypowstaniowej. Uosabiały ją dzieła prozaików Klemensa Junoszy-Szaniawskiego i Ignacego Chodźki czy malarza i ilustratora Franciszka Kostrzewskiego ${ }^{92}$. Mowa, rzecz jasna, o „nieuczonej”, popularnej wersji tej tradycji portretu obyczajowego, tkwiącej w podświadomości XX-wiecznych odbiorców piosenek Ficowskiego, w tradycji domowej, tradycji Cygana $z$ baśni $z$ dziecinnego pokoju, $z$ wypisów szkolnych, $z$ podręcznikowej czy także pocztówkowej ilustracji. Trwa ona również współcześnie, tworząc ową właśnie przestrzeń zamkniętą, arkadyjską, obrysowaną aurą dzieciństwa i najwcześniejszych wyobrażeń o świecie.

\section{Przychodzi do mnie nikt, czyli koncepty kontrastu i paradoksu ontologicznego}

Podobnie jak wizje anomalii natury, zgliszcz oraz dekompozycji świata - jako echa miłosnych rozstań - tak i obrazy świata uspokojonego i zamkniętego w czasie przeszłym, widzianego przez odwróconą lornetkę, odnoszą się do łatwych do nazwania deficytów psychologicznych. W pierwszym wypadku będzie to zwielokrotnione, melodramatyczne natężenie emocji, zwłaszcza poczucia krzywdy, w drugim - silnie odczuwane pragnienie bezpieczeństwa, swojskości, zadomowienia. Jednak nie wszystkie koncepty piosenkowe odwołują się do sfery emocji. Niektóre $z$ nich osadzone zostają w pewnych mechanizmach percypowania realności i kreuja dziwność świata poruszająca odbiorcę. Oparte są na paradoksie, kontraście, odwróceniu wy miarów. Chodzi tym razem o rozchwianie świata piosenkowego w samym punkcie wyjścia, natychmiastowe wprowadzenie słuchacza w sieć paradoksów, intrygująca dysharmonię, zaatakowanie go szeregiem alogiczności, zarówno przestrzennych, ontologicznych, jak i językowych, które uczynia go aktywnym wobec tekstu piosenki, „Zaproszą” do gry w realność i nierealność, zwiążą z sytuacją piosenkową.

Szukanie przez Ficowskiego składni kontrapunktowej (opartej na paradoksie), nicujące utarte oznajmienia, ujawnia się już w niektórych tytułach (szlagwortach) jego piosenek: Bez ciebie nie ma mnie, Bez ciebie tak mi dobrze, Przychodzi do mnie nikt, Jak dobrze, że to nie raj, Pokocham ciebie na złość. Co najmniej w paru utworach poeta ucieka się do kontrastu, który ustanawia bardzo czytelną zasadę organizacji piosenki, zarazem inicjuje zaskakujące, właśnie konceptualnie, i przyciągające uwagę przeciwstawienia aspektów świata. Biel i kolory w piosence Mieszkamy $w$ barwnych snach mają kilka wcieleń: są barwami świata (białe konwalie, wielobarwna tęcza), stłumioną lub rozbudzoną zmysłowością (anielska biel i gorąca tęcza), obojętnością lub miłością („Dalecy sobie mają sny / białe jak mleko”; „A my mieszkamy w barwnych snach”). W modlitwie młodego koniokrada (Czarna noc i biały koń) biel i czerń, nieoczekiwanie, chciałoby się rzec - po cygańsku, łączą 
się odpowiednio: biel ze złem (zagrażająca jasność księżyca) i czerń z dobrem (litościwa ciemność bezksiężycowej nocy, ukrywającej występek). Podobną, paradoksalną symbolikę bieli i czerni, uzależnioną od ludzkich afektów, spotykamy w piosence Noc i dzień (Boćkoryca).

Wyższym stopniem dziwności świata piosenkowego staje się widmowe przenikanie się granic materii - ciała i roślinności oraz żywiołów, budowanie trzecich wymiarów, obrazu nieistnienia tak intensywnego, że staje się istnieniem, przestrzenią nadliczbową. Tu już poruszamy się w klimatach leśmianowskich. $Z$ tym że piosenkowy koncept nie pozwala sobie na gubienie konturów świata, nie jest strumieniem wizji, oczekującym na interpretacje. Słuchacz zostaje „wrzucony” w sam środek owej dziwności, która rządzi się zaskakująco racjonalną logiką. Piosenka przecież musi być zrozumiana i zapamiętana, a jej odbiorca ma ograniczona zdolność przyswajania strumienia wyobraźni. W utworze Trzy pierścienie dziewczyna, zaślubiona $z$ wiatrem, słońcem i strumieniem, tłumaczy chłopakowi, że on ja zdobędzie, jeśli bystrością i siła dorówna tym trzem żywiołom. Kiedy indziej - jak w Cygańskiej letniej nocy - matką wszelkiego żywiołu jest „cygańska noc / roztańczona i bosa, / cygańska noc / z leśnym wiatrem we włosach”. I ona zachowuje się na swój sposób racjonalnie:

Kto wschodzący niańczy księżyc w chmurnych pieleszach i kto koniom na uprzęży zawiesza gwiazdy swe?

Naprawdę niezwykle jest tam, gdzie nigdy nie dotrzemy, ale właśnie piosenka pozwoli nam dostać się do tych niedosiężnych miejsc. Mityczna cygańska podróż w utworze Cygańska swoboda odbywa się w kierunku piątej strony świata, równie możliwej, jak pozostałe cztery:

Cygańska swoboda na palcach nam zaśwista, że ziemia jest kulista, że nie ma końca świat.

Niematerialność musi mieć w piosence materialne vehiculum, pojęcie bez takiego nośnika więdnie tu $\mathrm{z}$ braku powietrza. Tęsknota winna powołać do życia utraconego kochanka, jak w piosence Przychodzi do mnie nikt:

\footnotetext{
$Z$ tą ciszą szafirową, z tym ptakiem, który znikł, $z$ tą gwiazdą ponad głową przychodzi do mnie nikt.
}

Jeśli jest coś takiego, jak ukryta dusza cygańska, to jej tymczasowy adres i zawartość trzeba nazwać: będzie to stary jawor i schowane w nim „trzy wróżby z kart, / siódemka pik..." (Cygański skarb). Jeśli zakochana dziewczyna mówi o swej miłości, to jej substancje muszą mieć swoja wagę i objętość, jako tkwiące „pod drewnianym kamieniem”: „przytulone cienie”, „złoty sen”, „aksamitny nocy błam / i do nieba bilet" (Pod drewnianym kamieniem). 


\section{Kiedy porwę cię, dziewczyno, czyli koncepty} quasi-fabularne

Intuicja podpowiada, że w percepcji świata piosenkowego znacząca rolę powinien odegrać także pierwiastek fabularny, zdarzeniowy. Wydaje się, iż fabularność zawiera w sobie pewien potencjał naoczności, a zarazem niespodzianki, który łatwo złoży się na kolejny koncept piosenkowy, wyodrębniający przekaz tekstowy z nurtu melodii i skupiający uwagę słuchacza na wydarzeniach. Nośnikiem fabularności mógłby być schemat balladowy czy romansowy. Okazuje się jednak, że owa fabularność ma w piosenkach Ficowskiego swoiście wirtualny charakter, stanowi tylko pewną obietnicę, gest fabularny, nie zaś realne continuum zdarzeń, w którym uczestniczyłby słuchacz piosenki. Nie znaczy to wszakże, iż nie odgrywa ona roli konceptu piosenkowego. Właśnie w takim charakterze - quasi-fabularności - nadaje kontury wielu piosenkom, przywołując np. ów kod balladowy czy romansowy, jaki stwarza wyrazistą ramę monologów piosenkowych. Przykładem - Ballada cygańska, która, wbrew gatunkowej sygnaturze w tytule, nie prowadzi nas w istocie ku realnym zdarzeniom, ale nadaje balladową, niby-realną oprawę wyobraźni i baśniowości i dzieje się w świecie nierzeczywistym:

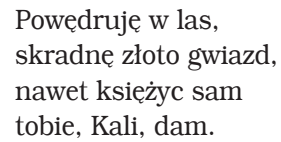

Podobnie Jada wozy kolorowe - opisują spełnienie tęsknoty za podróżą z Cyganami, która okazuje się czystą imaginacją:

\footnotetext{
No i pojechałam z nimi na kraj świata, wiatr warkocze mi rozplatał i zaplatał. I zbierałam dzikie trefle, leśne piki, i bywałam, gdzie rodziły się muzyki.
}

O tym, że nie fabuła stanowi istotę piosenek Ficowskiego, świadczą rozliczne utwory miłosne, w których $\mathrm{z}$ reguły mamy do czynienia $\mathrm{z}$ sytuacją umiejscowioną w czasie albo p o, albo przed zdarzeniem, czyli w momencie pewnej kulminacji emocji czy uczuć. I to owa kulminacja emocjonalna, nie zaś fabuła, jest głównym zdarzeniem piosenki miłosnej. Romans piosenkowy w stosunku do realnych zdarzeń albo używa czasu przeszłego:

$$
\begin{aligned}
& \text { Jesteś mi bardziej obcy dziś } \\
& \text { o całą zagubioną miłość, } \\
& \text { o każdą niepotrzebną myśl, } \\
& \text { o wszystko, co było. } \\
& \text { (Jesteś mi obcy) }
\end{aligned}
$$

To był tylko głupi błąd.

(Nic takiego) 
Tyle było powitań i rozstań,

tyle było słów: - żegnaj i - zostań.

(Więc nie dziw się)

Albo też żyje tym, co dopiero się zdarzy:

Znajdę drogę do twych oczu,
znajdę drogę do twych ust.

(Kali Mura)

Kiedy porwę cię, dziewczyno,

ślub nam księżyc da pod jodłą.

(Kiedy porwę cię, dziewczyno)

Przyjadę - we dwoje siądziemy na wóz

I będzie nas wiatr wędrowny niósł.

(Wędrowny wiatr)

Odejdziesz i tak,

jak lato odchodzi.

(Odejdziesz i tak)

Barwą zachodu cię napoję

jak starym winem.

Będziemy pili je oboje

$\mathrm{w}$ czarna godzinę.

(Taka prawda nieprawdziwa)

Wszystkie omówione przykłady wskazują na to, że koncept quasi-fabularny jest ideą fabularności, jest znakiem losu, czasu, ramą okalającą świat piosenki, postać bohatera, wyodrębniająca jego osobowość, stanowiąca punkt odniesienia dla jego emocji. Ze „streszczona”, skondensowaną fabularnością mamy także do czynienia w piosenkach podwórkowych Ficowskiego. Jej celem jest przede wszystkim zarysowanie rozpoznawalnych typów warszawskich, tak jak w piosenkach miłosnych jest nim wykreowanie pewnej wyrazistej sytuacji emocjonalnej i jej bohatera. Docieramy tu do kolejnego komponentu retoryki piosenek Ficowskiego, jaki stanowia portrety i charaktery.

Jak zostanę wielka pania, czyli portrety i charaktery

Zdradzające pewne podobieństwo do obrazków, o których już pisałem w związku z konceptem czasu zamkniętego, portrety i charaktery są w piosenkach częstym sposobem konkretyzacji świata, zapadającym we wrażliwość słuchacza. Stanowią jeszcze jedną figurę retoryki piosenkowej, łatwo przyswajalną i wyodrębniającą się z przekazu tekstowego. Działanie konceptu portretu czy charakteru polega na tym, że odbiorca piosenki staje naprzeciw pewnej wyrazistej persony, wobec której trudno mu być obojętnym. Albo uderza ona swoją życiową autentycznością, może więc stanowić potencjalne drugie ,ja” słuchacza piosenki, albo też, przeciwnie, wizerunek ów z góry zakłada nietożsamość postaci i słuchacza, uwodzi jednak w zamian swoją egzotyka, obcością.

Cały szereg portretów pierwszego rodzaju przynoszą niecygańskie piosenki 
miłosne, o których była wcześniej mowa w aspekcie stylu miłości piosenkowej. Tu wszakże mam na myśli aspekt, by tak rzec, charakterologiczny, silnie zarysowane cechy psychiczne postaci. Bohaterka piosenki Najszaleńszy szaławiła, porzucona przez chłopca-pędziwiatra, imponować może zimną krwią i pewnością siebie:

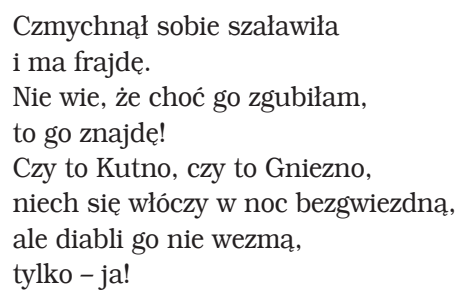

Na drugim biegunie - w piosence Strach ma wielkie oczy - znajdzie się zapewne portret dziewczyny obdarzającej swojego partnera nieograniczonym zaufaniem:

Bo przy tobie strach wielkie oczy mruży,

choćby zjawił się tuż-tuż,

taki staje się miły i nieduży,

że nie umie straszyć już!

Przy całej różnorodności owych charakterów zawsze jakoś wciagają one słuchacza w sytuację psychologiczną, stwarzają możliwość identyfikacji, myślenia w kategoriach: „a jak ja bym się w tej sytuacji zachował/zachowała?”

Obcość, odmienności Cygana, Cyganki, zdają się nie stwarzać możliwości takiej identyfikacji, jednak postacie te - w zamian niejako - zostają najczęściej wzbogacone rysem przełamującym schemat, uruchamiającym jakąś dialektykę: zarazem obcości i swojskości, wyższości i niższości. Cyganki Ficowskiego „odchylają się” od wzorca cygańskiego w kierunku naiwności, egzaltacji, czasem życiowego niefartu czy wyprowadzonego w pole sprytu. Słuchacz piosenki może tu łatwo przyjąć postawę wyrozumiałej wyższości. Tak zapewne odbiera Cygankę modlącą się do Boga o „czarnego chłopca”, „pantofelki” i „dwie kokosze” (Daj mi, Boże, pantofelki) oraz inną Cygankę, której marzy się chwilowa zamiana cygańskiej wędrówki na życie ,jak w Warszawie”, z szafa, fotelem i porcelaną (Jak zostane wielka pania), a także cygańską dziewczynę igrającą z miłością chłopca, w końcu jednak gubiącą się w tej grze i wziętą we władanie przez miłość (Dopóki jestem młoda), czy wreszcie bohaterkę piosenki Zaklęcia, której zawiłe karciane wróżby nie zapobiegną odejściu chłopaka.

I podobnie dzieje się $\mathrm{z}$ postaciami $\mathrm{z}$ folkloru warszawskiego. Bohater piosenki Taka ryba ma w sobie coś z typu warszawskiego cwaniaka, ale ów schemat zostaje komicznie przełamany, gdy przygoda wędkarska nad Wisłą kończy się wpadką matrymonialną, złowieniem grubej ryby („sto kilo bez ości”), co teoretycznie każdemu słuchaczowi piosenki mogłoby się zdarzyć, a więc zbliża tego bohatera do realności życiowej:

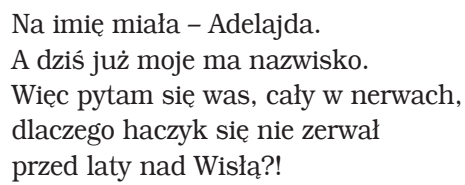


Charakter jako kategoria, figura piosenkowej retoryki jest konceptem w dużym stopniu definiowanym także przez wykonawcę piosenki, który może nadać postaci szczególną sugestywność, wyprowadzić ze schematu (jak w interpretacjach Randii, Burana czy Stępowskiego). Wykonawca może również sam wpisać w piosenkę swój styl artystyczny, osobowość, de facto ustanawiająca, kreująca postać, która „ciagnie” utwór w kierunku przeboju. Taką właśnie historię ma piosenka Jada wozy kolorowe. Pierwotnie wykonywały ja Maryla Lerch i Helena Majdaniec, ale stała się ona przebojem dopiero w interpretacji Rodowicz ${ }^{93}$.

Nasze słowa sa ze srebra, czyli koncepty językowe Konstrukcją nośną, konceptem piosenek Ficowskiego jest często gra językowa. Od razu jednak trzeba zauważyć, że podstawową funkcję tej gry - tak jak w przypadku każdego innego konceptu piosenkowego - stanowi uspójnianie tekstu słownego i nadawanie mu wyrazistości. To zasadniczo różni piosenkowa grę językową od praktyk lingwistycznych w poezji, które zakładają wielokrotną lekturę tekstu i czynią wydarzenia w języku tematem wiersza, źródłem polisemii. Jej wykrywanie jest w trakcie lektury zadaniem dla czytelnika i warunkiem pełnej konkretyzacji utworu poetyckiego. Słuchacz piosenki estradowej nie ma, rzecz jasna, kompetencji i czasu, by podejmować tego rodzaju interpretacje strumienia tekstu zanurzonego w melodii. Operacje językowe w piosence służą jej błyskawicznemu „ogarnięciu” przez odbiorcę, mogą być zasadą organizująca piosenkę, jej „czytanie”, nadająca jej własne, rozpoznawalne oblicze.

Chyba najbardziej „rozrzedzoną” formułę konceptu językowego realizują te piosenki Ficowskiego, w których silny jest żywioł konwersacyjny, piosenki-rozmowy, a właściwie monologi wypowiedziane, np. nasycone kolokwializmami piosenki miłosne, jak chociażby utwór Nic takiego:

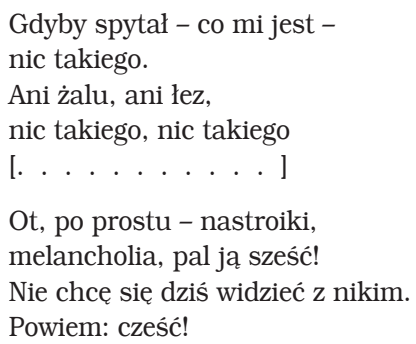

Czy piosenka Takjest lepiej:

\author{
Po imieniu chce pan? Lekkomyślnie. \\ Dwa kieliszki, wie pan, i czar pryśnie. \\ Tak jest lepiej, radzę panu szczerze, \\ niech pan słucha w porę mych ostrzeżeń.
}

Silnie i od początku zdefiniowana tu zostaje rola słuchacza piosenki - jako „tego 
trzeciego" - arbitra w sporze?, przypadkowego świadka?, słuchacza (lub podsłuchiwacza) cudzych zwierzeń? Odbiorca utworu uzyskuje czytelny sygnał co do swoich kompetencji, usytuowania, sposobu „czytania” piosenki.

Kolejnym, bardziej już skondensowanym konceptem językowym jest osadzenie piosenki w idiomie językowym w ścisłym sensie. Ficowski wielokrotnie czyni rdzeniem piosenki albo konkretny zwrot frazeologiczny, albo - jeszcze częściej - przysłowie. I tu znów musimy powrócić do istoty konceptu, sumowania w nim łatwo rozpoznawalnej oczywistości (idiom, przysłowie) i momentu komplikacji, intrygującej niespodzianki (przetworzenie). W piosenkach Spalony most czy Wiatr mieszka $w d z i k i c h$ topolach istotną rolę ekspresyjną odgrywa nasycenie popularnych idiomów treścią wizualną, nagłe wypełnienie nieważkiej, zdawało się, materii słownej takich zwrotów, jak „palić za sobą mosty” czy „szukać wiatru w polu” wizyjnością burzliwą jak uczucie zakochanych:

\section{Przez spalony most biegnie $z$ wiatrem głos}

i szuka cię, i woła cię $z$ dala!

(Spalony most)

Nie szukaj wiatru w polu,
wiatru - który zamilkł.
Wiatr mieszka w dzikich topolach
razem z ptakami.

(Wiatr mieszka $w$ dzikich topolach)

Przysłowia natomiast, jako punkt orientacyjny piosenek, bywają przekształcane w swej warstwie językowej, tekst piosenki przypominać zaczyna kalambur, w którym właśnie nie wyjście poza słowo, ale modyfikacja znanego zwrotu, osadzenie w żywej treści, dynamizują czy dramatyzują piosenkę, otwierają obszar komplikacji semantycznej. Jest tak w utworze Nasze słowa sa ze srebra, w którym sygnalizowane w tytułowym szlagworcie przysłowie, ale i później przywołane powiedzenie „na dwoje babka wróżyła” - zostają wpisane w romans, w jakim „cisza wróży nam na dwoje”, a dziewczyna prosi o „chociaż trochę / srebrnych słów”. Rozsypywanie się logiki idiomu stanowi znak narastających komplikacji uczuciowych, także gdy bohaterka powiada: „na wszelki wypadek wyrzeknę się marzeń”, „,na wszelki wypadek - zapomnę" (Nadzieja na dwoje nam wróży). Głęboka dysonansowość między nadzieją wpisaną w idiom „na wszelki wypadek” a brakiem nadziei w dopowiedzeniach („wyrzeknę się marzen”, ,zapomnę)) rodzi tu szczególny dramatyzm.

Kulminację konceptów językowych przynoszą piosenki, których istota jest zabawa słowem, traktowana jako cel pierwszoplanowy. I takie utwory znajdują się w dorobku Ficowskiego, który jako posiadacz wielu talentów, również owe - w ścisłym sensie - gry językowe dołączył do swojej kolekcji konceptów piosenkowych. $\mathrm{W}$ tych grach rządzi przede wszystkim zasada homonimii, idealnie godząca element zaskoczenia ze wskazywaniem słuchaczowi czytelnej zasady konstrukcyjnej tekstu. $Z$ reguły pojawia się tu także pierwiastek komizmu. Piosenka Poszedł teść do sklepu operuje homonimicznymi skojarzeniami takich wyrazów i zwrotów, jak „rybka mrożona” i jej substytut detaliczny „ucho od śledzia”, „kwaszona kapusta” i „skwaszona mina”, „kiszka kaszana” i „kiszki, / które marsza grają”.

Całą ścieżkę homonimiczną - wywiedzioną ze źródłosłowu „palić-zapalać” - 
buduje $z$ kolei 10-zwrotkowa piosenka Zapalny John (współaut. E. Bussold). Tu już zasada homonimii staje się właściwie pierwszą przyczyną utworu, oferującego poza tym czy raczej - w rezultacie tego - purnonsensowa historyjke o Johnie podpalaczu:

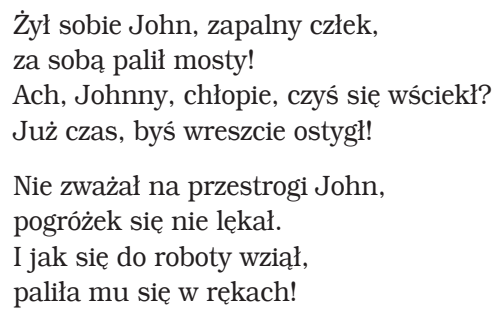

Warto zauważyć, że przyjęcie podobnej apriorycznej reguły inicjuje surrealny świat (fabułę) także w klasycznych wierszach anglojęzycznej poezji absurdalnej, np. w limeryku, gdzie świat ten - jak o tym pisze Stanisław Barańczak - zawiązuje się $z$ kolei wokół rymu inicjalnego ${ }^{94}$.

\section{Kontekst poezji}

Podany tu przegląd konceptów piosenkowych Ficowskiego zapewne dałoby się jeszcze nieco poszerzyć. Chciałbym jednak podkreślić, że zawsze, w poszczególnych konceptach, dominuje swoiście pragmatyczny aspekt kształtowania tekstu słownego, czyli dążenie do jego wyrazistości i zrozumiałości w strumieniu melodii. Służy temu nadawanie mu cech zarazem schematyczności, konwencji i - w ograniczonym zakresie - nowości, niepowtarzalności, niespodzianki. Już samo wyodrębnienie grup konceptów wskazuje na istnienie owych schematów, pewnego rodzaju receptur piosenkowych. Piosenka estradowa tworzona przez poetę, który przemienia się w tekściarza, nie jest jednak, oczywiście, pozbawiona znamion jego poetyckiego zaplecza. Trzeba zatem spytać, co staje się z tym zasobem wrażliwości poetyckiej w momencie, gdy ów poeta zmienia pióro.

Unikając tu elementu jakiegokolwiek wartościowania, można skonstatować, że tekst piosenkowy nie zna maksymalizmu poezji w zakresie pomnażania znaczeń. Inaczej niż wiersz, nie stawia odbiorcy wobec wieloznacznych sensów, które z czasem mają doczekać się jego interpretacji. Gdy prześledzimy kolejne koncepty piosenkowe, wyodrębnione tu według owego pragmatycznego kryterium dominanty retorycznej, to odnajdziemy w nich szczątki, niepełne formy, zredukowane i ujednoznacznione realizacje elementów języka i wyobraźni poetyckiej Ficowskiego. Podkreślmy - będą to elementy, na które założono swoiste wędzidło po to, aby tekst słowny tworzył czytelny przekaz, stanowiący równoważne i wyraziste dopełnienie muzyki.

S. Barańczak, Zamiast wstępu. W: Fioletowa krowa. 333 najsławniejsze okazy angielskiej i amerykańskiej poezji niepoważnej od Williama Shakespeare'a do Johna Lennona. Antologia. Poznań 1993, s. 21: „rasowy limeryk musi iść [...] za logiką rozwoju wydarzeń narzuconą przez rym pierwszej linijki [...]". 
Tak więc np. przywołana wcześniej w grupie konceptów pejzażu du chow e g o piosenka O-lejli-hej przynosi obraz świata odwróconego pod wpływem nieszczęśliwej miłości:

\author{
Droga nie biegnie, \\ góra nie stoi, \\ nic nie ma oprócz tęsknoty mojej.
}

Obraz ten wydaje się uproszczonym echem, powtórzeniem poetyckiej operacji przestrzennej dokonanej w wierszu Milczenie ziemi z cyklu Odczytanie popiołów, opisującym miejsce niegdyś dokonanej zagłady Żydów:

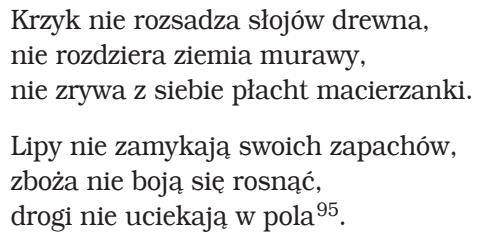

W porównaniu $z$ sentymentalną wizją piosenki miłosnej katastroficzne odwrócenie krajobrazu w wierszu o Zagładzie jest, po pierwsze, odwróceniem nie do k o n a n y m - i przez to ukazuje właśnie tragizm obojętności świata wobec zbrodni. Zdaje się mówić: świat po tej zbrodni nie oszalał, choć powinien. Ponadto nie jest ono, owo odwrócenie, usytuowane w sferze przeżyć pojedynczej „duszy cierpiącej”, lecz wpisane w rozległa - społeczną, etyczną, ontologiczną, historiozoficzna refleksję o Zagładzie.

Analogia między piosenką a wierszem (w podanym przykładzie jest to pewien pomysł obrazowy, ze szczególnym podobieństwem jednego tylko wersu: „droga nie biegnie” - „drogi nie uciekaja”) przybiera niekiedy charakter dosłownego cytatu. Tak więc pojawiający się w piosence Daj mi tęczę na niedzielę fragment „parasol srebrnym deszczem / zacerujesz sobie dziś!" odnajdujemy jako wyodrębnioną przez autora wersalikami puentę wiersza Mój fach szczęśliwy z tomiku Ptak poza ptakiem (1968):

\author{
Dzięki ci losie \\ nie jestem głodny \\ suchar rozpaczy chowam \\ na czarna godzinę \\ na razie zarobię na szczęście \\ Jestem poeta \\ mam fach w ręku - \\ CEROWANIE \\ DZIURAWYCH \\ PARASOLI \\ DESZCZEM $^{96}$
}

Z tego samego tomiku pochodzi także wiersz Bliskość niewidoma, subtelne, operujące paradoksem przestrzennym studium rozstania. Jego fragment: 


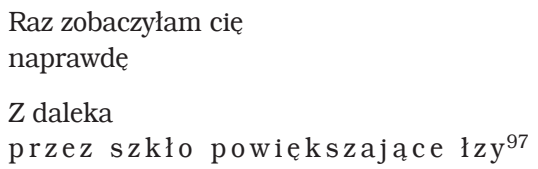

- pojawia się z kolei w piosence miłosnej Więc nie dziw się, wykonywanej przez Geppert:

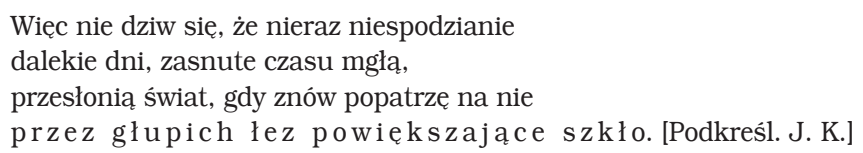

Warto zauważyć, że w każdym wypadku dotyczącym takich cytatów bądź zapożyczeń - choć trudno jest ustalić, ze względu na brak precyzyjnych datowań utworów, czy przeniesienie nastąpiło $z$ wiersza do piosenki, czy odwrotnie - ujęcie, które w wierszu stanowiło element silnie osadzony w logice poetyckiej i ją współtworzyło, w piosence podporządkowane zostaje nadrzędnemu konceptowi i wydaje się, że wpisuje się w nią przede wszystkim emocjonalnie, ma status ornamentu, wpadającego w ucho bon mot.

Jeśli z kolei rozważymy ową grupę k o n c e p tó w subs ta n cjalny ch, których istota jest posłużenie się składnikami krajobrazu, materią, żywiołami jako figurami pewnych prawd o życiu, to trzeba powiedzieć, iż czerpią one $z$ wierszy, z wyobraźni poetyckiej Ficowskiego takie intensywne w jego theatrum poetyckim tropy, jak personifikacja, animizacja czy reifikacja. Znajdujemy w jego piosenkach personifikujące metafory - wcześniej już tu wskazywane - rzeki-dziewczyny (Naga rzeka), róży-miłości (Najczerwieńszy kwiat), łkającej gitary (Najwierniejsza gitara), księżyca-podglądacza (Nie zawracaj nam głowy, księżycu). Ale widzimy, oczywiście, że zakres tych rekwizytów metaforycznych, przy całej świeżości konkretnych przedstawień, jest silnie konwencjonalny, a ponadto służy definiowaniu pewnej wyrazistej, jednowymiarowej dramaturgii, najczęściej powiązanej z podmiotem, bohaterem piosenkowej opowieści.

Personifikacje, animizacje, reifikacje w wierszach Ficowskiego nie znają, rzecz jasna, takich ograniczeń i owej, występującej w piosenkach, służebności wobec ulotnej dramaturgii uczuciowej, przez nie kreowanej. Zawsze są wpisane w rozległy dyskurs, z reguły wyprowadzaja nas z sytuacyjnego „tu i teraz” wiersza, stanowia część, czasem nośnik, poetyckiej narracji, np. historycznej, jak choćby w Balladzie o trzech mociumpańskich:

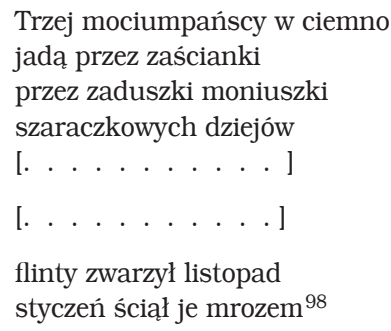


Prawda, że cała ta ballada tkwi w XIX-wiecznych realiach, że stanowi - jak powiada Piotr Sommer - „swoisty wehikuł czasu” 99, ale animizacja w dwóch ostatnich cytowanych wersach, przywołująca miesiące powstańcze, dźwiga ten wehikuł na orbitę refleksji o historii w sposób, przyznajmy, szczególnie spektakularny. Podobnie jak gwałtownie rozszerzająca horyzont utworu personifikacja w wierszu W temperaturze 38 i $5 \ldots$ z końca lat siedemdziesiątych XX wieku. Pojawia się w nim „Z sakwojażem uchodźcy / stary kaszel / wyleczony z Franza Kafki”, jakby chciał obwieścić wówczas, w latach apogeum PRL-owskiej cenzury, powtórkę lęków Procesu? Kolonii karnej? A w każdym razie mówi:

\author{
[...] mój Maksie \\ wybaczam ci Tylko \\ co zrobić $\mathrm{z}$ tym \\ stutomowym milczeniem \\ Maksie mój Maksie \\ spal tę moją ciszę 100
}

Kiedy poszukujemy w piosenkach Ficowskiego stanów dwuznaczności ontologicznej, paradoksów, przesuwania się wymiarów, wędrówek poza widzialność, np. w „stronę piąta” świata (Cygańska swoboda), czy tajemniczych bytów-pojeć uosabiających szczęście (Pod drewnianym kamieniem) lub cygańskość (Cygański skarb), to $\mathrm{w}$ istocie znajdujemy w tych przekształceniach dziwność i słyszymy pogłosy utworów Bolesława Leśmiana, który obok Schulza i Wojtkiewicza był, jak wiadomo, jednym $z$ artystycznych mistrzów Ficowskiego. Magia i baśniowość, znikanie i pojawianie się bytów, metamorfozy, przemiana liści w monety, ciał w żywioły, wszystkie te koncepty obrazowe, zwłaszcza częste w nurcie piosenek „cygańskich”, choć zdarzające się i w piosenkach miłosnych (Przychodzi do mnie nikt) - także, oczywiście, prowadzą nas ku poezji Ficowskiego.

Jednak znów musimy zauważyć, że jeśli w piosenkach te pierwiastki są trzymane na uwięzi konwencji, ograniczone prawie całkowicie do idiomu cygańskiego, jego magii, cudowności, egzotyki, to w wierszach przemieniają się one w poetyckie traktaty fenomenologiczne, w zadziwienia naturą, Kosmosem, czasem. Już nie wyłącznie cudowność, magia, czarodziejstwo, ale również, a może przede wszystkim, chęć uniesienia pewnych problemów poznawczych, antropologicznych, refleksji historiozoficznej rządzi w wierszach Ficowskiego. Przykładem są choćby transformacje - personifikacje czy reifikacje poetyckie - które ujawniaja zmienną naturę czasu.

Może więc on trwać, jakby zatrzymany, w postaci starej kanapy na strychu domu dziadków:

Tu ćmiła jeszcze kongresówka, kanapa się w niej zasiedziała ${ }^{101}$.

P. S o m m e r, Przewroty słów, zawroty czasu. (Notatki o poezji Jerzego Ficowskiego). W: Po stykach. Gdańsk 2005, s. 55.

100 J. Fic ow ski, W temperaturze 38 i 5... W: Gryps. Warszawa 1979, s. 15.

101 J. Fi cow s ki, Zaręby Kościelne (rzecz o końcu świata). W: Goraczka rzeczy, s. 92. „Królestwo Kongresowe [...] od niechcenia przeobraża się w coś na kształt kopcącej naftówki” - pisze traf- 
Kiedy indziej, w wierszu Kwatera AK, będzie to czas postarzałych córek bohaterów, które muszą pomieścić w sobie lata życia własnego i dodatkowo, wcześnie poległych ojców; we fragmencie „przychodzą do nich córki przygarbione / to s tary k a w ał czasu" 102 stają się one jakby nieruchomą bryłą czasu, o ciężarze ponad ich miarę. Czas nie zatrzymany, ale przeciwnie - „poganiany” społeczną tęsknota mieszkańców kraju zniewolonego, pojawia się w poemacie Pojutrznia (1981-1982) za sprawa gorzko-ironicznej metafory „lornety Dybicza” czy rozbudowanej personifikacji:

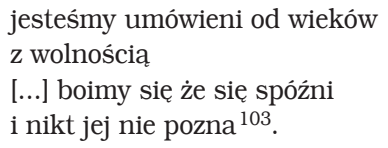

A wreszcie, redukujący rys konceptów piosenkowych - w porównaniu z poezją - widać, gdy zestawia się gry językowe w piosenkach z niezwykła, kreatywną wyobraźnią językową wierszy Ficowskiego ${ }^{104}$. Koncepty językowe piosenek mają zdecydowanie bardziej, by tak rzec, plebejski czy ludyczny charakter, mocniej odwołują się do żywiołu potoczności. Znacznie więcej w nich np. przekształconych przysłów, także w typie piosenek, które nazwałem tu inteligenckimi (w grupie utworów satyrycznych czy miłosnych). Gra przysłowiami, mającymi własność wpadania w ucho (m.in. „Strach ma wielkie oczy”, „Na dwoje babka wróżyła”, „Słowo się rzekło, kobyłka u płota"), dobrze wpisuje się w regułę konceptu piosenkowego - w zasadę oczywistości, której towarzyszy innowacja, zatrzymująca uwagę słuchacza. Natomiast w wierszach Ficowskiego odwołań do przysłów jest niewiele, rodziłoby to bowiem w poezji ryzyko banalizacji ${ }^{105}$.

Możliwość porównań stwarzają za to realizowane w piosenkach i w wierszach przekształcenia idiomów i homonimie. Przytoczone w opisie konceptów jezzykowych przykłady wskazują, że w piosenkach mamy do czynienia przede wszystkim z formą ka la mbur u, wiążącego gre językową $\mathrm{z}$ efektem humorystycznym lub z intencją satyryczną (Poszedł teść do sklepu, Zapalny John, Kobyłka u płota). Nawet taka perełka homonimiczna jak w piosence Bajka o cygańskim królu:

Aż dziś spotkałem go nareszcie:

w talii kart siedział jak w areszcie!

nie S o m mer (op. cit., s. 34) o tym fragmencie, pozostawiając jednak nieco na uboczu samą kanapę, której „zasiedzenie (się)” jest źródłem fabularności i zniewalającej animacyjności całej tej sceny.

J. Ficowski, Kwatera AK. W: Goraczka rzeczy, s. 220. Podkreśl. J. K. Można by tę reifikację określić trafnym mianem „czas zdziczały”, wprowadzonym przez monografistkę Ficowskiego, P. C zwordo n (Empatia i obserwacja. O poezji Jerzego Ficowskiego. Poznań 2010, s. $111 \mathrm{n}$.$) .$

103 J. Fic ow s ki, Pojutrznia. W: Przepowiednie. - Pojutrznia. Wyd. 2. Warszawa 1985, s. 21-22.

104 O lingwistycznych aspektach poezji Ficowskiego dogłębnie pisali S o m mer (op. cit.), a później C zword on (op. cit., s. 57-64), w swej monografii ujmująca to zjawisko na szerszym tle poezji powojennej.

105 C z w o r d o n (op. cit., s. 57) odnajduje pogłosy przysłów w funkcji magicznej, jako „dobre omeny”, w cyklu $Z$ mitologicznej encyklopedii w tomie Amulety i definicje z 1960 roku. 
Jest królem winnym, winnym bardzo, ale Cyganki nim nie wzgardzą. [Podkreśl. J. K.]

- wpisuje się bez reszty w poetykę kalamburu, gdyż pojawia się w kontekście cygańskiej baśniowości.

Wypada powtórzyć, że o ile w piosence homonimia czy gra idiomem wytyczają pewna ścieżkę odbioru tekstu słownego, ,prowadzą" słuchacza jako czytelna zasada organizacji utworu, o tyle w wierszach, przeciwnie, rola zwłaszcza homonimii jest odwracanie wymiarów świata, otwieranie nowych ścieżek lektury, niekiedy wręcz „przełączanie” utworu pomiędzy rejestrami, np. intymności i historii, sytuacyjnego konkretu i uogólnienia, materii i refleksji moralnej ${ }^{106}$. W wierszu Nieśmiertelność - w centrum biografii Antoniego Słonimskiego (którego pamięci dedykowany jest ten utwór):

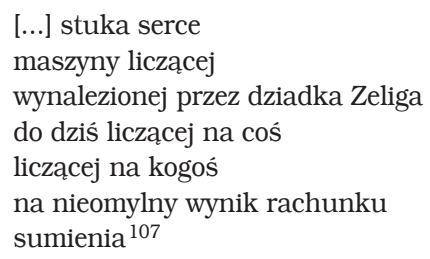

Rodzaj moralistyki, jaki wyłania się tutaj za sprawą homonimii, połączonej dodatkowo z personifikacją, jest jak najdalszy od mentorstwa, wymykający się wszelkiej retoryce. Podobnie w opowieści na poły historycznej, poemacie Pojutrznia, z okresu stanu wojennego, gdy mowa o naukach ojców, Ficowski podąża tropem homonimicznym, oddalającym bogoojczyźniany patos, zbliżającym do łagodnej ironii:

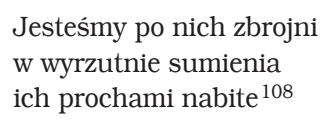

Zauważmy także, jak z kolei gorzka ironia zawiera się $\mathrm{w}$ przytoczonej już wcześniej reifikacji starych córek, $\mathrm{z}$ wiersza Kwatera AK: „to sta ry kaw ał czasu", a to dlatego, że zarazem stanowi ona przykład finezyjnej homonimii poetyckiej. Wreszcie zaś wspomnijmy o przypadku, w którym homonimia nagle odwraca kierunek wiersza, $\mathrm{z}$ pozoru będącego tylko sceną $\mathrm{z}$ rannym akowcem, leżącym na wozie ciagnionym przez konia, i kieruje obiektyw utworu jakby na twarz samego podmiotu wiersza, na jego nieodpuszczoną winę, poruszająco wydobywając sens autobiograficzny:

[...] Nie było mnie przy tym 30 lat odrabiam swoją nieobecność w zaprzęgu kary stary sen ${ }^{109}$

Chyba to właśnie ma na myśli S o m me r (op. cit., s. 30), gdy pisze: „Język "Ficowskiego wiersza" modyfikuje status ontologiczny przedstawianego świata, modyfikuje sposób poznawania go i mówienia o nim, modyfikuje też porządek panującego nam czasu, bo naturalnie do niego także stosują się odwrócone hierarchie Jerzego Ficowskiego".

107 J. Fi cow ski, Nieśmiertelność. W: Goraczka rzeczy, s. 147.

108 Fi cow ski, Pojutrznia, s. 15.

109 J. Fic ow ski, Defilada. W: Goraczka rzeczy, s. 221. 
Przejdźmy zatem na koniec do wniosków tyczących relacji wiersz-piosenka, $\mathrm{w}$ realizacjach Jerzego Ficowskiego i w sensie ogólniejszym. Kiedy tylko w tym wywodzie staram się ukazać odmienność światów poetyckich w stosunku do piosenkowych, przedstawić poetyckie losy piosenkowych figur czy poetyckie źródła piosenkowych fraz i ujęć, otwierają się - widać to bardzo wyraźnie - skomplikowane ścieżki znaczeń poetyckich, rozrastają się i mnożą eksplikacje, ujawnia się narracyjna wielokierunkowość wierszy. Sporo to mówi, jak sądzę, o zasadniczej różnicy między piosenką a wierszem. Czytając wiersz, podążamy tropem zmiennych sensów, śledzimy nawroty znaczeń, gwałtowne niekiedy otwarcia się przestrzeni utworu, rozwój i rozwarstwianie narracji, podwójność, symultanizm światów. Czytając piosenkę, skupiamy się na zjawisku kumulacji potencjału słownego w czytelny, kinetyczny przekaz, który ma swój wyraźny środek ciężkości, wyraźny wektor, określony przez koncept piosenkowy. Siła piosenki leży poza różnorodnością, odkrywczością figur i znaczeń, jest nie tyle kumulacją znaczeń, ile emocji, namiętności, które ulegają rozładowaniu, stają się czyjąś „twarzą" ${ }^{110}$.

Można więc powiedzieć, że piosenka w żadnym razie nie stanowi cienia wiersza, uproszczonej wersji poezji. Jest silnie sfunkcjonalizowana, wysokoenergetyczną konstrukcją, która w krótkim przedziale czasu realizuje pewną trudną koincydencję między porcją informacji, budujących przekaz słowny, sytuację emocjonalną, a linią melodyczną, równie niezbędną, $z$ czego razem wynika maksimum energii uczuciowej i maksimum treści skierowanych do słuchacza. Piosenka w warunkach ciśnień nieporównanie większych niż poezja realizuje swoją misję artystyczną. Cały mój wywód, połączony z wyodrębnieniem konceptów retoryki piosenkowej, de facto unieważniający określenie „poetyka piosenki” - jako podporządkowujące ten gatunek wierszowi, a za to preferujący termin „retoryka piosenkowa” - jako akcentujący zasadniczą odmienność sposobów budowania znaczeń, reguł oddziaływania piosenki na odbiorcę, służyć ma ukazaniu, że gatunek ten jest po prostu odrębną domeną twórczości, rządzącą się swoimi prawami.

Jeśli wrócimy na chwilę do opisanych konceptów piosenkowych, to widzimy, że nie migotliwość znaczeń, poetycki hologram, genezyjska potencja słowa, ekscytujące i wymagające skupionej uwagi śledzenie krystalizacji sensów są ich istota, ich ofertą dla słuchacza. Przeciwnie, ich zasada jest osadzenie w prostych regułach percepcji ludzkiej (przestrzeń zamknięta oraz otwarta), w substancjach, materiach i żywiołach świata, w sytuacyjności i anegdocie, w rozróżnieniach realności i marzenia, jawy i snu, wreszcie w konwersacyjności lub w grze językowej, opartej na cytacie (przysłowia) czy komizmie słownym (kalambur). A także na spojeniu wszystkich tych pierwiastków rymem oraz rytmem wersów, dominacją szlagwortu, regułą przemienności canto i refrenu.

110 Trafnie o tym pisze M. Tr a c zy k (Poezja w piosence. Od Tuwima do Świetlickiego. Poznań 2009, s. 22), który wskazuje na pierwszoplanowość w piosence, w odróżnieniu od poezji, funkcji impresywnej: „Funkcję tę należy rozumieć jako przyzwolenie, a wręcz wymóg takiego ukształtowania tekstu (oraz pozostałych elementów składających się na piosenkę: muzyki, sposobu wykonania), aby oddziaływał on na emocje odbiorcy, zmuszał go do reakcji emocjonalnej”. I dalej badacz stwierdza: „piosenka staje się elementem jednostkowej biografii i jednostkowego doświadczenia, osobistą pamiątką. Staje się Piosenką" (ibidem, s. 23). 
Piosenka zatem zwraca się do odbiorcy innego niż czytelnik poezji. Jej życie okazuje się bliższe jego życiu. Jest ona nakierowana nie na siebie samą, ale na ludzi, którzy chcą w niej rozpoznać własne doświadczenia, tęsknoty. Dlatego piosenkę - poza owym faktem, że jej tekst słowny musi konkurować z melodią, być równie jak ona wyrazisty - konstytuują także inne warunki zewnętrzne, odmienna rola w komunikowaniu artystycznym niż rola poezji. Jaka to jest rola? Myślę, że bardziej a r c h a i c z n a, bo powiązana $z$ melicznością, rytmem, oralnością, somatyzmem i podświadomością ${ }^{111}$. A zarazem, paradoksalnie, silniej, by tak rzec, r e c e ptyw na, bo odpowiadająca na największe współczesne głody emocjonalne, wrażliwość, wyobraźnię, wzorce życia swoich słuchaczy. Czyni to, oczywiście, piosenkę bardziej niż poezja ulotną i przemijającą ${ }^{112}$.

Ficowski jako poeta wielokrotnie dystansował się od swoich piosenkowych zatrudnień, a jego poezja rzeczywiście różni się zasadniczo od twórczości piosenkowej. Konsekwentnie nierymowana nie porusza się na fali emocjonalnej, nie podchwytuje cudzego tętna, jakichś pierwotnych rytmów. Ma w sobie jądro racjonalizmu, „czyta” mity i historię, daleka jest od irracjonalnych zasłuchań i prostej receptywności uczuć. To poezja najświadomiej wiążąca opisy świata realnego z pogłosami języka, tu właśnie, w miejscu zetknięcia się owych dwóch przestrzeni, powołująca do życia swoje światy. I wobec tego nie znajdujemy w niej owej dyspozycji aranżera, kreatora cudzych emocji, nie ma w niej także inklinacji retorycznych, jakie występują w piosence. Ficowski sądził, że to właśnie różni go od Juliana Tuwima, niegdyś jego mistrza, i określił tę różnicę, wspominając swój zbiór wierszy Moje strony świata:

wydany po Październiku w 1957 roku [...] był dla mnie jakimś tomikiem przełomowym. I tak sobie

111 Zob. inspirowane koncepcjami W. Onga uwagi A. Ni ewiary (Piosenka-gatunek ewoluujacy? W zb.: Gatunki mowy i ich ewolucja. T. 2: Tekst a gatunek. Red. D. O s t a s zew ska. Katowice 2004, s. 202) o przynależności piosenki do kultury oralnej, formułowane w nawiązaniu do wartościujących sądów A. Barańczak na temat tekstów piosenek. Niewiara (ibidem, s. 204-205) snuje ciekawe refleksje o historycznej zmienności gatunku, o przejściu piosenki z fazy oralnej do piśmiennej (do której należała omawiana tu przez nas piosenka estradowa), przez co „doświadczyła [...] etapu wartościowania, czego w kulturze oralnej nie (za)znała”, a następnie o współczesnym powrocie piosenki do kultury oralnej, czego wyrazem jest „piosenka rockowa, ze wszystkimi współczesnymi odmianami - punk, metal, w końcu rap".

112 E. B a lc e r za n (Popularność literatury a, literatura popularna”. 〈Na przykładzie poezji i piosenki〉. W zb.: Problemy socjologii literatury. Red. J. Sła w in s ki. Wrocław 1971, s. 242) w poczatkach lat siedemdziesiątych stwierdzał celnie, że „dominanta języka piosenki jest czytelne nastawienie na aktualny system społecznych koniunktur", gdy tymczasem dominantą języka poezji jest programowy brak takiego nastawienia. Szkic Balcerzana w wielu miejscach akcentuje odrębność wiersza i piosenki. Badacz podkreśla - z czym należy się w pełni zgodzić - że istota piosenkowości sytuuje się poza poetyckością. O takim jego spojrzeniu na piosenkę świadczy np. następująca obserwacja (odwołująca się do kategorii J. Przybosia „wiersza słabego” i „wiersza mocnego”): „Najpoważniejsze [...] szanse zespolenia się z muzyką ma wiers z słaby. Wiersz, który łatwo rezygnuje z poetyckich nadwyżek znaczeniowych, i dopiero w realizacji słowno-muzycznej, w piosence, ujawnia swoją urodę" (ibidem, s. 246). Spośród współczesnych badaczy młodszego pokolenia ten sposób myślenia, podkreślający odrębność piosenki popularnej względem poezji (choć we wprowadzeniu do rozważań o poezji śpiewanej), wyraziście reprezentuje przywołany tu wcześniej Tr a c zy k (op. cit.). Duża część jego ciekawej książki poświęcona jest opisowi sposobów adaptacji tekstów poetyckich do reguł piosenki. 
wtedy pomyślałem, że nie ma już Tuwima między nami od kilku lat, ale gdyby był, to pewno uważałby to za regres w mojej twórczości. Bo jednak on bardzo był zrośnięty z tym [...] gatunkiem, w którym był Tuwimem - jednym ze skamandrytów, jednym z poetów epoki, gdzie praca nie tylko nad słowem, ale nad wersyfikacją, nad rymem, była czymś pierwszorzędnym. Tak że gdyby się z tym [tomikiem] zetknął, tak jak pochwalił Zwierzenia $\mathrm{z} 1952$ roku, tak by prawdopodobnie zasmucił się ${ }^{113}$.

My jednak konsekwentnie nie przyjmujemy tezy o pośledniości, wtórnym charakterze twórczości piosenkowej, którą Ficowski wielokrotnie wypowiadał. Bo nie tylko w poezji wyraził on swą tożsamość artystyczną, ale też w piosence. I także dlatego jego związków $z$ Tuwimem nie przekreśliły nowe poszukiwania poetyckie po 1956 roku $^{114}$. Piosenka wyrażała jakby drugie „ja” Ficowskiego i, jak się wydaje, równie silnie, choć na inny sposób, osadzona jest we wrażliwości, w poznawczych dyspozycjach tego autora. Oto bowiem koncept piosenkowy, retoryka piosenkowa, wyznaczaja wektor odmienny niż poezja, rzec można - horyzontalny. Powtarzalności, konwencjonalności, przewidywalności piosenkowych konceptów towarzyszy „ruch wszerz”, wchłanianie tematów, rodzenie się k ole k c ji. (I tu Ficowski także spotyka się z Tuwimem.) Twórczość piosenkowa Ficowskiego, daleka od maksymalizmu jego poetyckich poszukiwań, stanowi jednak, jak nietrudno się zorientować, kolekcję jego tematów, a tym samym, w najszerszym sensie, staje się jakby modelem jego świata, mapa fascynacji, na której osobne miejsca zajmują np. postacie Cyganów, folklor starej Warszawy, natura, baśń, inicjujące odrębne motywy i nurty tematyczne piosenek. I ten model, ta mapa wyobraźni Jerzego Ficowskiego wydają się czynnikami jednoczącymi wszystkie jego poczynania artystyczne.

\section{Abstract \\ JERZY KANDZIORA Institute of Literary Research of the Polish Academy of Sciences, Warsaw \\ JERZY FICOWSKI'S SONG OFFER (FROM THE HISTORY OF POPULAR CULTURE IN POLISH PEOPLE'S REPUBLIC)}

The study analyses stage song's lyrics by an eminent poet Jerzy Ficowski, an effect of his minor and gainful creative activity, yet important as a set of pieces that belongs to Polish People's Republic popular culture mainstream. It presents the institutional aspect of composing and distributing of song, the problem of the text's corrections and the authorship liquidity resulting from market expectations. Attention is paid to the myths and life models included into the songs, themes of love, gipsy and city, as well as the cases of restrain and squeezing the songs' plots from the stage circulation due to political reasons. The theoretical part includes investigations into the song's peculiar rhetoric, and offers linguistic-pictorial concepts present in Ficowski's lyrics. The distinctive rules of song production and the song reception is given against the background of the author's exclusively poetic creativity.

113 Jerzy Ficowski - refleksje i wspomnienia. Cz. 5: Jerzy Ficowski snuje refleksje o życiowych marzeniach i pasjach. Na stronie: http://www.polskieradio.pl/8/755/Artykul/364583,Jerzy-Ficowski\%E2\%80\%93-refleksje-i-wspomnienia (data dostępu: 19 VI 2016).

114 Kwestia, w jakim stopniu „filozofia słowa” Tuwima towarzyszyła Ficowskiemu w całej twórczości, to temat do osobnych rozważań. 